\title{
11. PALEOMAGNETISM OF LATE MESOZOIC TO HOLOCENE SEDIMENTS FROM THE BAY OF BISCAY AND ROCKALL PLATEAU, DRILLED ON IPOD LEG 48
}

\author{
Ernest A. Hailwood, Department of Oceanography, University of Southampton, S09 5NH, U.K.
}

\begin{abstract}
Paleomagnetic results are described from IPOD Holes 400/400A, 401, and $402 \mathrm{~A}$ in the northeast Bay of Biscay, and Sites 403,404 , and 405 at the southwest extremity of the Rockall Plateau. A detailed Pleistocene-late Miocene polarity reversal record has been established for Hole 400A, and comparison with the established Pleistocene and late Neogene polarity time scale allows the determination of precise sediment accumulation rates at this site for the past 10 million years. A fairly complete magnetic polarity record also has been derived for the sequence of Early Cretaceous (Aptian-Albian) "black-shales"' in Holes 400A and 402A; this record indicates that the entire section recovered was deposited during the long Early Cretaceous interval of dominantly normal magnetic polarity. A sequence of rapid reversals has been identified in late Albian sediments in both holes, and is correlated with the "mixed polarity zone" of similar age at DSDP Site 263 (Green and Brecher, 1974). No evidence has been found for a prolonged interval of reverse polarity in the uppermost Aptian sediments that might correspond with the late Aptian "Gatan zone" identified by Pechersky and Khramov (1973), and correlated by some authors with marine magnetic anomaly $M O$.

The mean inclination of stable magnetism from the 150 samples of "black shale" from Hole 402A has been used to derive the paleolatitude of this site in Early Cretaceous times, and the resultant value is in good agreement with the Early Cretaceous pole position for western Europe, derived by van der Voo and French (1974), from a synthesis of marine magnetic anomaly data and paleomagnetic determinations from the circum-Atlantic continents. Discontinuous magnetic polarity records have been derived from the Paleocene to middle Eocene sediments recovered from Hole 400A and Site 401, and normal polarity intervals, corresponding with magnetic anomalies 22 and 23 are tentatively identified at sub-bottom depths of approximately 560 and 585 meters in Hole 400A, and 172 and 183 meters at Site 401 . At Sites 403 and 404 on the southwest margin of the Rockall Plateau, a thick sequence of volcanic tuffs, siltstones, and glauconitic muds of late Paleocene-early Eocene age was penetrated. The entire 130 -meter section at Site 403 and the lowermost 90 meters at Site 404 is reversely magnetized throughout, and is thought to have been deposited during the long reverse polarity interval which preceded anomaly 24 . Biostratigraphic studies of these sediments provides important new control on the age of anomaly 24 , which has been identified at a depth of 280 meters at Site 404, near the base of nannofossil Zone NP 12, and within dinocyst Zone II of Costa and Downie (this volume). Since this is the oldest magnetic anomaly identified in the northeast Atlantic, these results provide a precise biostratigraphic determination of the age of opening of the northeast Atlantic.

Finally, magnetic susceptibility and intensity values are shown to provide a useful basis for correlation between sites. For example, a sharp decrease in susceptibility and intensity occurs within the NP 14 nannofossil zone, close to the early/middle Eocene boundary at both Hole $400 \mathrm{~A}$ and Site 401. This is considered to represent an abrupt reduction in the rate of supply of terrigenous material at the end of the early Eocene, due to a change in circulation pattern or sediment source area. Similarly, narrow zones of high susceptibility and intensity at certain depths in the volcanogenic sediments of Sites 403 and 404 appear to represent specific tuffaceous horizons, which can be correlated from one site to the other.
\end{abstract}




\section{INTRODUCTION}

This paper describes the results of a shipboard paleomagnetic study, carried out on sediments recovered from the continental slope and rise environment of the northeast Bay of Biscay and southwest Rockall Plateau, during the course of Leg 48 of the International Phase of Ocean Drilling of the Deep Sea Drilling Project. The motivation for this study was three-fold. Firstly, it was anticipated that shipboard magnetic polarity determinations might provide a useful source of information, which would complement and augment paleontological information on the geological ages of the formations drilled. Secondly, the identification of a sequence of magnetic polarity reversals in the sedimentary sequence, that could be matched with the pattern of magnetic anomalies recorded in the underlying oceanic lithosphere, could provide important corroboration of proposed models of sea-floor-spreading history. It would also permit a more exact timing to be established between geological events recorded in the sediments (e.g., as lithological changes, or sedimentary hiatuses), and possible plate tectonic causes. Finally, the possibility of determining paleolatitudes from the paleomagnetic data provides an opportunity for an independent test of Mesozoic and early Cenozoic continental reconstructions, based on marine magnetic anomalies and continental paleomagnetic data (e.g., Van der Voo and French, 1974).

\section{Paleomagnetic Techniques}

The paleomagnetic measurements on Leg 48 were carried out with the equipment installed on Glomar Challenger and first used on Leg 47, comprising a "Digico" computerized spinner magnetometer for measurement of discrete samples having volumes in the range of 10 to $20 \mathrm{~cm}^{3}$, and an AF demagnetizer incorporating a 2-axis tumbling system, enclosed in a mu-metal shield. The manually driven current reduction system used on Leg 47 was replaced by a variable speed reversible motor-driven system, which allowed automatic increase of the demagnetizing field to a predetermined peak value, and smooth decrease to zero. The incorporation of this system permitted a single experienced operator to simultaneously measure one sample, and demagnetize another, with a consequent halving of the total processing time for each sample. With efficient organization of time, it was found possible to routinely process between 30 and 40 samples per day, involving one NRM measurement, and an average of two (often up to four) demagnetization steps per sample. The noise level of the magnetometer usually lay in the range 0.02 to $0.06 \mu \mathrm{G}$ (micro Gauss), and satisfactory measurement repeatability was possible for most samples using an integration time corresponding to $2^{7}$ revolutions. In the case of many samples, further post-cruise studies were carried out in the paleomagnetism laboratory at Southampton, to confirm initial measurements made on the ship.

\section{Sampling Procedure}

In the relatively soft unconsolidated and semiconsolidated sediments encountered in the upper parts of the holes, paleomagnetic samples were taken by pushing $2.5-\mathrm{cm}$-diameter plastic tubes of $2.2 \mathrm{~cm}$ length into the split core sections by means of a specially designed plunger, supported by an aluminum bridge. The ends of the sample tubes were sealed with adhesive tape. In the more highly lithified material encountered at deeper levels, 2.5-cm-diameter cylindrical samples were drilled from the cores, or cube-shaped samples were cut by means of a diamond saw, and trimmed to shape using a stainless steel scalpel. In all cases an orientation arrow pointing in the uphole direction was carefully placed on the sample before removal from the core. Where inclined bedding was encountered, and considered due to either non-vertical drill penetration or local movement of portions of the core during drilling, the orientation arrow was aligned perpendicular to the bedding, rather than parallel with the core liner.

\section{Assignment of Polarity}

Unlike conventional short piston or gravity cores, DSDP cores are drilled by means of a rotating drill pipe (except in the uppermost very soft sediments). This process can cause relative rotation (called "disking") between different parts of the core section, with consequent apparent changes in the declination of magnetic remanence. Furthermore, the absolute azimuthal orientation of the cores is not measured, and relative azimuthal orientation is not maintained from one 9.5-meter core to the next. For this reason the declination of remanent magnetization is of limited use, except within individual cores in which disking is absent, or in the uppermost few cores at each site, which are commonly drilled without rotation.

Consequently, in this study the magnetic polarity has been assigned on the basis of the inclination of the stable component of remanent magnetization alone. Since all sites are situated at moderate to high latitudes in the Northern Hemisphere, positive magnetic inclinations are taken to signify a normal polarity, and negative inclinations a reversed polarity. Occasionally in a series of samples taken from undisturbed portions of the same drill core, polarity reversals detected on the basis of changes in sign of magnetic inclination were corroborated by abrupt changes in declination of approximately $180^{\circ}$.

\section{PALEOMAGNETIC RESULTS}

\section{Bay of Biscay (Holes 400/400A, 401, 402A)}

The Biscay sites were drilled at the northeast margin of the Bay of Biscay, in the vicinity of the Meriadzeck Terrace. Holes $400 / 400$ A was located in water depth of 4,400 meters, at the base of the continental slope, and Site 401 was located on the edge of the Meriadzeck Terrace at a water depth of 2500 meters, in a situation where pre-drift sediments could be penetrated at relatively shallow depths beneath the sea floor. Hole $402 \mathrm{~A}$ was drilled in a canyon on the mid-continental slope at a water depth of 2400 meters, in an attempt to penetrate shallow water equivalents of the deeper facies encountered at Holes 400/400A and 401.

\section{Site 400}

A single core, of Pleistocene age, was retrieved immediately below the sediment-water interface at Site 400 and, initially, one paleomagnetic sample was taken from 
each of the seven 1.5-meter sections. Positive inclination values ranging from $3^{\circ}$ to $60^{\circ}$ were observed in all sections except the first, and AF demagnetization to 300 Oe resulted in very little change of direction, confirming the stable nature of this magnetic remanence. The single sample from Section 1 yielded an inclination of $-45^{\circ}$, and therefore an additional eight samples were taken from this section, to establish whether or not this negative inclination represented a true field reversal during the Brunhes normal magnetic epoch. The magnetic parameters are plotted in Figure 1, in which a negative inclination zone defined by three samples is apparent at a depth of approximately 1.4 meters.

The relative declination values in this core section remain within the range $160^{\circ}-220^{\circ}$, suggesting that "disking" or

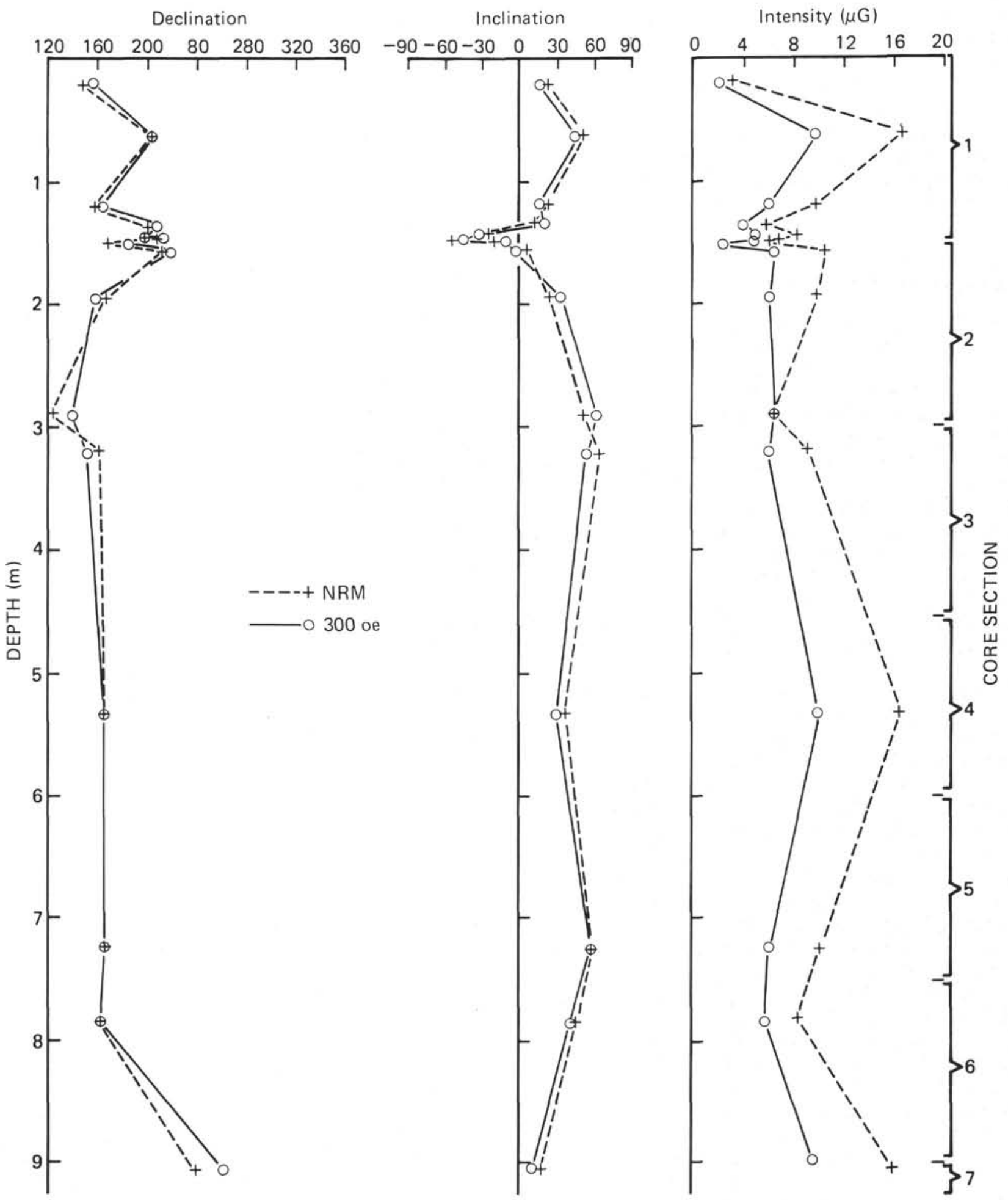

Figure 1. Downhole plot of declination, inclination, and intensity of magnetization for Site 400, Core 1 (Pleistocene). Magnetic "excursion" occurs at a depth of 1.4 meters. 
other forms of core disturbance are unimportant. The interval of negative inclination appears to correspond with a consistent increase in declination of about $40^{\circ}$, compared with an anticipated change of $180^{\circ}$ for a true field reversal. It is concluded that this interval may represent a magnetic "excursion," (possibly an effect of the Earth's non-dipole field, and of limited geographical extent) rather than a true reversal. If this feature can be located in the uppermost parts of other cores from this region, it may prove to be a useful datum for correlation purposes. Using the accumulation rate of 82 meters $/ \mathrm{m}$.y. derived from the uppermost part of the nearby Hole 400A (see next section), the age of this "excursion" would be approximately 20,000 years B.P. Short period geomagnetic "excursions" at about 18,000 to 20,000 years have been reported from a number of other localities (e.g., Bonhommet and Zahringer, 1969; Nakajima et al., 1973), and may well by synchronous with the one reported here.

\section{Hole 400A}

\section{Sampling and Stability Tests}

A total of 219 paleomagnetic samples (Table 1) were taken at this hole, spaced at intervals of one sample per 1.5-meter core section above 520 meters sub-bottom, and two samples per section below this depth. Each sample was subjected to partial AF demagnetization at several different peak $\mathrm{AF}$ values in the range of 50 to $500 \mathrm{oe}$. Wherever possible, demagnetization was continued until it was considered that an unambiguous and reliable determination of polarity of the stable component of magnetic remanence had been achieved. Fields of 50, 150, and 300 oe were found appropriate for the majority of samples in the depth range 0 to 122 meters, but low NRM intensities prohibited the use of fields greater than 200 oe for most samples in the depth range 122 to 210 meters, and 50 oe for the range 210 to 475 meters. Below this depth the majority of samples were demagnetized at 100 and 300 oe.

Figure 2a illustrates the response to AF demagnetization of several samples from the upper marls and nannofossil chalk oozes. A high proportion of the samples exhibit a moderate to high stability, as illustrated by the normally magnetized Sample 400A-7-1, 44-46 cm, and the reversely magnetized Sample 400A-5-1, $44-46 \mathrm{~cm}$. The latter samples maintain an inclination close to the theoretically predicted value for the latitude of this site (broken circle in Figure 1). The remanence direction of occasional samples, such as the reversely magnetized Sample 400A-2-1, 117-119 cm, continues changing up to the maximum applied field, suggesting that a secondary component (possibly aligned along the present geomagnetic field direction) has not been completely removed. Sample 400 A-2-2, 36-38 cm shows dominantly unstable behavior, but A.F. demagnetization appears to result in the removal of a normally magnetized component superimposed on a reverse component.

Figure $2 \mathrm{~b}$ illustrates the stability behavior of several samples from the very weakly magnetized nannofossil chalks and slightly stronger marly chalks and interbedded mudstones from below 500 meters sub-bottom. Samples 400A-47-1, $15-17 \mathrm{~cm}$, and $400 \mathrm{~A}-52-1,7-9 \mathrm{~cm}$, demonstrate the removal of a normal component of magnetization close to the present geomagnetic field inclination, and the isolation of a more stable reverse component. Although the identification of this reverse component is based on only a single demagnetizing step ( $300 \mathrm{Oe})$ in the latter sample, it is significant that both this sample and Sample 400A-52-1, 109-111 cm were taken from the same core section, and after demagnetization at 300 Oe the reversal indicated by the difference in polarity of inclination is confirmed by the near $180^{\circ}$ difference in declination.

\section{Magnetic Inclination Values}

A histogram of the magnetic inclination of all 219 samples from this site after AF demagnetization at the "optimum" field value is shown in Figure 3. A bimodal distribution of positive and negative values, corresponding to normal and reverse magnetizations, is apparent, but the peaks are displaced away from the theoretical axial geocentric dipole value at this latitude (broken lines) towards lower inclinations. Because these samples range in age from Cretaceous to Recent, this shallowing of magnetic inclinations may be partly due to the northward motion of the European plate in post-Early Cretaceous times. However, other possible contributing factors include syn-depositional gravitational rotation of magnetic mineral grains (King, 1955), persistent non-dipole geomagnetic field components (Hailwood, 1977), or the effect of compaction causing magnetic minerals to lie with their long axes close to the horizontal plane (Keen, 1963). The peak for negative inclinations shows a larger displacement from the theoretical value than that for positive inclinations, possibly reflecting the incomplete removal of secondary normal components in many of the reversely magnetized samples.

\section{Magnetic Polarity Record for Hole 400A}

Figure 4 shows a downhole plot of magnetic inclinations after optimum demagnetization, together with the inferred polarity reversal sequence, and the position of nannofossil and foraminifer zones determined in these cores at the time of writing. A correlation between the Pleistocene and upper Miocene polarity sequence and the "standard" polarity time scale for the past 10 million years is shown in Figure 5. The correlation allows the determination of relatively precise sediment accumulation rate values, and the assignment of "absolute" ages to the biostratigraphic zonal boundaries identified at Hole 400A. The former aspect is discussed in a later section of this chapter, and the latter aspect in the Leg 48 magnetobiostratigraphic synthesis chapter (Hailwood et al., this volume). Core recovery was less continuous throughout the Paleogene sequence at Hole $400 \mathrm{~A}$, and this has resulted in a fragmentary polarity record. Consequently precise correlation with the established polarity reversal time scale over this interval is difficult.

The sediments recovered from Cores 62 to 74 , beneath the Maestrichtian/late Albian uncomformity, lie within the lower part of the long Cretaceous interval of constant normal polarity (e.g., van Hinte, 1976). However, a sequence of five closely spaced short reversals are present within the Praediscosphaera cretacea and Eiffellithus turriseiffeli nannofossil zones of the late Albian (Figure 4). These appear to correlate well with the three short reversals identified by Green and Brecher (1974), and Jarrard (1974) in late Albian sediments at DSDP Site 263, and designated "Site 263 Mixed Zone" 
TABLE 1

Hole 400A: Paleomagnetic Results

\begin{tabular}{|c|c|c|c|c|c|c|c|c|c|c|c|}
\hline \multirow{2}{*}{$\begin{array}{c}\text { Sample } \\
\text { (Interval in } \mathrm{cm} \text { ) }\end{array}$} & \multirow[b]{2}{*}{ Depth } & \multirow[b]{2}{*}{ Dec. } & \multirow{2}{*}{$\begin{array}{l}\text { NRM } \\
\text { Inc. }\end{array}$} & \multirow[b]{2}{*}{ Int. } & \multirow{2}{*}{$\begin{array}{l}\text { Demag. } \\
\text { Field }\end{array}$} & \multicolumn{3}{|c|}{ After Demagnetization } & \multirow[b]{2}{*}{ Polarity } & \multicolumn{2}{|c|}{ Category ${ }^{\mathrm{a}}$} \\
\hline & & & & & & Dec. & Inc. & Int. & & Polarity & Direction \\
\hline $1-1,93-95$ & 75.44 & 50.0 & 24.8 & 0.11 & 50 & 56.5 & 37.6 & 0.02 & $\mathrm{~N}$ & 3 & 4 \\
\hline $1-2,8-11$ & 76.10 & 294.5 & 46.9 & 0.25 & 150 & 271.9 & 29.2 & 0.17 & $\mathrm{~N}$ & 2 & 3 \\
\hline $2-1,117-120$ & 85.18 & 40.2 & -26.5 & 0.42 & 300 & 43.3 & -52.6 & 0.71 & $\mathrm{R}$ & 1 & 2 \\
\hline $2-2,36-38$ & 85.87 & 135.0 & 32.4 & 0.38 & 150 & 279.3 & -47.3 & 0.12 & $\mathrm{R}$ & 2 & 3 \\
\hline $2-3,17-19$ & 87.18 & 82.9 & -68.5 & 0.36 & 150 & 38.7 & -63.4 & 0.29 & $\mathrm{R}$ & 1 & 3 \\
\hline $2-4,79-81$ & 89.30 & 168.6 & -40.0 & 0.40 & 150 & 149.2 & -31.2 & 0.32 & $\mathrm{R}$ & 1 & 2 \\
\hline $2-5,34-36$ & 90.35 & 323.5 & -33.1 & 0.14 & 50 & 339.7 & -5.8 & 0.09 & $\mathrm{R}$ & 3 & 3 \\
\hline $2-6,44-46$ & 91.95 & 176.5 & 54.1 & 0.07 & 50 & 302.1 & -8.9 & 0.05 & $\mathrm{R}$ & 3 & 3 \\
\hline $3-1,134-137$ & 94.85 & 319.5 & 13.8 & 0.05 & 100 & 183.3 & -41.7 & 0.05 & $\mathrm{R}$ & 2 & 3 \\
\hline $3-2,57-60$ & 95.58 & 101.7 & 11.9 & 0.19 & 100 & 33.0 & 15.9 & 0.03 & $\mathrm{~N}$ & 2 & 3 \\
\hline $3-3,55-58$ & 96.57 & 265.4 & 54.5 & 0.06 & 100 & 291.2 & 28.6 & 0.10 & $\mathrm{~N}$ & 2 & 4 \\
\hline $3-4,78-80$ & 98.29 & 185.4 & 27.4 & 0.60 & 100 & 209.7 & 16.1 & 0.44 & $\mathrm{~N}$ & 1 & 2 \\
\hline $3-4,93-95$ & 98.44 & 112.3 & -63.2 & 1.07 & 150 & 134.3 & -60.8 & 0.37 & $\mathrm{R}$ & 1 & 3 \\
\hline $4-3,130-132$ & 107.31 & 324.2 & 47.7 & 0.08 & 100 & 292.9 & 50.1 & 0.08 & $\mathrm{~N}$ & 3 & 3 \\
\hline $4-4,45-48$ & 107.96 & 65.0 & 44.5 & 0.17 & 100 & 5.0 & -56.7 & 0.11 & $\mathrm{R}$ & 3 & 3 \\
\hline $4-5,69-72$ & 109.71 & 25.6 & 51.9 & 0.11 & 150 & 109.8 & -47.2 & 0.06 & $?$ & 4 & 4 \\
\hline $5-1,44-46$ & 112.95 & 339.8 & -63.6 & 0.40 & 150 & 319.4 & -68.6 & 0.46 & $\mathrm{R}$ & 1 & 2 \\
\hline $5-2,10-12$ & 114.11 & 294.3 & -28.0 & 0.12 & 150 & 276.5 & -30.9 & 0.15 & $\mathrm{R}$ & 1 & 2 \\
\hline $6-1,64-66$ & 122.65 & 46.4 & -57.5 & 2.66 & 150 & 50.0 & -58.6 & 2.98 & $\mathbf{R}$ & 1 & 1 \\
\hline $6-2,9-11$ & 123.60 & 33.2 & -46.9 & 1.61 & 150 & 29.7 & -51.1 & 1.72 & $\mathrm{R}$ & 1 & 1 \\
\hline $6-3,92-94$ & 125.93 & 107.9 & 48.3 & 0.19 & 50 & 100.4 & 28.3 & 0.09 & $\mathrm{~N}$ & 1 & 3 \\
\hline $7-1,44-46$ & 131.95 & 64.1 & 67.7 & 0.14 & 200 & 48.0 & 71.5 & 0.13 & $\mathrm{~N}$ & 1 & 1 \\
\hline $7-2,54-56$ & 133.55 & 312.6 & 47.5 & 0.10 & 50 & 286.3 & 52.4 & 0.13 & $\mathrm{~N}$ & 2 & 3 \\
\hline $7-3,76-78$ & 135.27 & 258.9 & 73.1 & 0.14 & 100 & 258.7 & 62.2 & 0.11 & $\mathrm{~N}$ & 1 & 2 \\
\hline $8-1,64-67$ & 141.66 & 320.6 & 29.4 & 0.08 & 100 & 293.6 & 64.7 & 0.07 & $\mathrm{~N}$ & 2 & 4 \\
\hline $8-2,101-103$ & 143.52 & 246.5 & 61.8 & 0.18 & 50 & 212.1 & 36.8 & 0.06 & $\mathrm{~N}$ & 1 & 3 \\
\hline $8-3,69-71$ & 144.70 & 353.8 & 28.8 & 0.13 & 50 & 28.0 & -37.7 & 0.13 & $\mathrm{R}$ & 1 & 3 \\
\hline $8-4,67-69$ & 146.18 & 19.1 & 45.8 & 0.12 & 100 & 300.3 & -6.3 & 0.07 & $\mathrm{R}$ & 2 & 2 \\
\hline $8-5,82-84$ & 147.83 & 318.3 & 23.0 & 0.08 & 50 & 301.0 & 23.9 & 0.09 & $\mathrm{~N}$ & 2 & 4 \\
\hline $8-6,60-62$ & 149.10 & 38.1 & 12.0 & 0.06 & 100 & 50.6 & 70.6 & 0.09 & $\mathrm{~N}$ & 1 & 3 \\
\hline $9-1,41-43$ & 150.92 & 287.8 & 39.8 & 0.11 & 150 & 88.2 & 6.7 & 0.11 & $\mathrm{~N}$ & 3 & 3 \\
\hline $9-2,84-86$ & 152.85 & 29.7 & 14.3 & 0.18 & 50 & 356.1 & 28.7 & 0.04 & $\mathrm{~N}$ & 3 & 4 \\
\hline $9-3,45-48$ & 153.97 & 1.7 & 85.5 & 0.18 & 150 & 267.8 & 21.0 & 0.06 & $\mathrm{~N}$ & 3 & 4 \\
\hline $9-4,86-88$ & 155.87 & 260.9 & 38.4 & 0.10 & 50 & 266.1 & 28.4 & 0.06 & $\mathrm{~N}$ & 3 & 3 \\
\hline $9-5,48-50$ & 156.99 & 50.8 & -12.1 & 0.11 & 100 & 253.6 & 45.6 & 0.08 & $\mathrm{~N}$ & 2 & 3 \\
\hline $9-6,35-37$ & 158.36 & 254.0 & -56.7 & 1.15 & 50 & 260.1 & -57.1 & 0.34 & $\mathrm{R}$ & 1 & 3 \\
\hline $9-7,9-11$ & 159.60 & 33.6 & -36.1 & 0.14 & 200 & 247.7 & -7.9 & 0.06 & $\mathbf{R}$ & 2 & 3 \\
\hline $10-1,140-142$ & 161.41 & 253.6 & 55.8 & 0.30 & 200 & 124.1 & 24.9 & 0.07 & $\mathrm{~N}$ & 3 & 4 \\
\hline $10-2,45-48$ & 161.96 & 292.4 & 14.4 & 0.10 & 100 & 210.0 & 34.2 & 0.06 & $\mathrm{~N}$ & 1 & 3 \\
\hline $10-3,40-42$ & 163.41 & 259.8 & -9.9 & 0.07 & 50 & 301.2 & -20.7 & 0.01 & $\mathrm{R}$ & 2 & 3 \\
\hline $11-2,9-11$ & 171.10 & 137.0 & -48.0 & 0.20 & 100 & 105.7 & -24.9 & 0.35 & $\mathrm{R}$ & 1 & 2 \\
\hline $12-7,8-10$ & 188.90 & 261.5 & 59.5 & 0.04 & 100 & 59.1 & -36.8 & 0.04 & $\mathrm{R}$ & 3 & 4 \\
\hline $13-6,66-68$ & 196.67 & 54.7 & 60.8 & 0.07 & 150 & 45.5 & 45.0 & 0.11 & $\mathrm{~N}$ & 1 & 3 \\
\hline $14-1,94-96$ & 198.95 & 315.5 & 7.7 & 0.04 & 50 & 3.0 & -7.0 & 0.03 & $\mathrm{R}$ & 3 & 4 \\
\hline $14-2,84-87$ & 200.36 & 353.0 & 36.9 & 0.04 & 50 & 47.6 & -5.2 & 0.04 & $\mathrm{R}$ & 3 & 4 \\
\hline $14-3,14-16$ & 201.15 & 84.8 & 31.5 & 0.05 & 50 & 86.8 & 27.9 & 0.03 & $?$ & 4 & 4 \\
\hline $15-1,141-143$ & 208.92 & 291.8 & 34.2 & 0.04 & 50 & 312.7 & 72.8 & 0.03 & $\mathrm{~N}$ & 3 & 4 \\
\hline $15-2,120-122$ & 210.21 & 49.8 & 42.9 & 0.09 & 50 & 88.2 & 77.1 & 0.05 & $\mathrm{~N}$ & 2 & 3 \\
\hline $15-3,58-60$ & 211.09 & 198.6 & -1.4 & 0.19 & 50 & 214.4 & -5.5 & 0.19 & $\mathrm{R}$ & 2 & 3 \\
\hline $15-4,113-115$ & 213.14 & 324.2 & -42.8 & 0.09 & 50 & 349.0 & -14.4 & 0.05 & $\mathrm{R}$ & 2 & 3 \\
\hline $15-5,5-7$ & 213.56 & 279.2 & -7.4 & 0.07 & 50 & 297.3 & 27.2 & 0.04 & $\mathrm{~N}$ & 2 & 3 \\
\hline $16-7,7-9$ & 226.58 & 10.6 & 2.5 & 0.07 & 50 & 6.4 & -17.8 & 0.09 & $\mathrm{R}$ & 2 & 3 \\
\hline $17-1,86-88$ & 227.37 & 39.9 & 21.7 & 0.10 & 50 & 49.6 & 30.9 & 0.08 & $\mathrm{~N}$ & 2 & 2 \\
\hline $17-2,62-64$ & 228.63 & 263.0 & 32.8 & 0.11 & 50 & 235.7 & -23.6 & 0.07 & $\mathrm{R}$ & 2 & 3 \\
\hline $17-3,44-46$ & 229.95 & 59.9 & 84.2 & 0.10 & 50 & 102.2 & 59.6 & 0.01 & $\mathrm{~N}$ & 3 & 4 \\
\hline $17-4,89-91$ & 231.90 & 223.1 & 38.8 & 0.05 & 50 & 357.8 & -58.2 & 0.07 & $\mathrm{R}$ & 2 & 3 \\
\hline $17-5,79-81$ & 233.30 & 127.8 & 84.9 & 0.12 & 100 & 326.0 & -13.1 & 0.12 & $\mathrm{R}$ & 1 & 4 \\
\hline $18-1,17-20$ & 236.15 & 179.6 & 44.0 & 0.23 & 100 & 189.0 & 49.5 & 0.14 & $\mathrm{~N}$ & 1 & 2 \\
\hline $18-2,45-47$ & 237.96 & 238.6 & 1.6 & 0.02 & 50 & 221.0 & -16.0 & 0.09 & $\mathrm{R}$ & 3 & 4 \\
\hline $18-3,83-85$ & 239.84 & 253.5 & -7.9 & 0.14 & 150 & 223.2 & -43.0 & 0.12 & $\mathrm{R}$ & 2 & 3 \\
\hline $18-4,99-101$ & 241.50 & 301.7 & -61.6 & 0.18 & 50 & 281.3 & -23.4 & 0.09 & $\mathrm{R}$ & 2 & 3 \\
\hline $18-5,77-79$ & 242.78 & 179.4 & 44.4 & 0.32 & 100 & 148.7 & -11.8 & 0.07 & $\mathrm{R}$ & 2 & 3 \\
\hline $18-6,120-122$ & 244.71 & 268.8 & -46.9 & 0.09 & 50 & 49.7 & -79.4 & 0.35 & $\mathrm{R}$ & 2 & 3 \\
\hline $19-1,76-78$ & 246.27 & 1.0 & 3.3 & 0.03 & 50 & 256.3 & -36.6 & 0.09 & $\mathrm{R}$ & 2 & 3 \\
\hline $19-2,135-137$ & 248.36 & 329.9 & 70.2 & 0.15 & 50 & 200.2 & 72.2 & 0.10 & $\mathrm{~N}$ & 2 & 3 \\
\hline $19-3,54-52$ & 249.05 & 328.0 & 30.4 & 0.05 & 50 & 329.4 & -47.1 & 0.04 & $\mathrm{R}$ & 2 & 3 \\
\hline $19-4,114-116$ & 251.15 & 141.9 & 2.4 & 0.07 & 50 & 93.3 & 9.1 & 0.07 & $\mathrm{~N}$ & 2 & 3 \\
\hline
\end{tabular}


TABLE 1 - Continued

\begin{tabular}{|c|c|c|c|c|c|c|c|c|c|c|c|}
\hline \multirow{2}{*}{$\begin{array}{c}\text { Sample } \\
\text { (Interval in } \mathrm{cm} \text { ) }\end{array}$} & \multirow[b]{2}{*}{ Depth } & \multirow[b]{2}{*}{ Dec. } & \multirow{2}{*}{$\begin{array}{l}\text { NRM } \\
\text { Inc. }\end{array}$} & \multirow[b]{2}{*}{ Int. } & \multirow{2}{*}{$\begin{array}{l}\text { Demag. } \\
\text { Field }\end{array}$} & \multicolumn{3}{|c|}{ After Demagnetization } & \multirow[b]{2}{*}{ Polarity } & \multicolumn{2}{|c|}{ Category $^{\mathrm{a}}$} \\
\hline & & & & & & Dec. & Inc. & Int. & & Polarity & Direction \\
\hline $19-5,28-30$ & 251.79 & 121.2 & 45.3 & 0.07 & 50 & 126.5 & 40.6 & 1.76 & $\mathrm{~N}$ & 2 & 2 \\
\hline $20-1,113-115$ & 256.14 & 214.6 & 67.1 & 0.08 & 50 & 250.8 & 73.0 & 0.12 & $\mathrm{~N}$ & 2 & 3 \\
\hline $20-2,121-123$ & 257.72 & 8.9 & 21.3 & 0.10 & 50 & 22.3 & 31.9 & 0.14 & $\mathrm{~N}$ & 2 & 3 \\
\hline $20-3,59-61$ & 258.60 & 210.4 & 57.3 & 0.08 & 50 & 93.2 & -78.9 & 0.03 & $\mathrm{R}$ & 3 & 3 \\
\hline $20-4,101-103$ & 260.52 & 56.4 & 68.1 & 0.10 & 50 & 111.4 & 72.9 & 0.08 & $\mathrm{~N}$ & 2 & 3 \\
\hline $20-5,31-33$ & 261.31 & 323.5 & 65.7 & 0.13 & 50 & 205.6 & 25.4 & 0.05 & $\mathrm{~N}$ & 3 & 3 \\
\hline $20-6,8-10$ & 262.59 & 200.9 & 59.1 & 0.13 & 50 & 160.0 & 9.6 & 0.07 & $\mathrm{~N}$ & 3 & 3 \\
\hline $21-4,98-100$ & 270.00 & 45.8 & 20.6 & 0.10 & 50 & 153.8 & -78.6 & 0.07 & $\mathrm{R}$ & 2 & 3 \\
\hline $22-6,34-36$ & 281.85 & 312.6 & 59.3 & 0.14 & 50 & 270.9 & 44.3 & 0.08 & $\mathrm{~N}$ & 2 & 3 \\
\hline $23, \mathrm{CC}, 15-18$ & 293.00 & 336.7 & 59.4 & 0.09 & 50 & 89.7 & 23.0 & 0.06 & $\mathrm{~N}$ & 3 & 3 \\
\hline $24-6,79-81$ & 301.30 & 37.0 & -34.8 & 0.06 & 50 & 18.2 & -2.5 & 0.01 & $\mathrm{R}$ & 3 & 3 \\
\hline $24, \mathrm{CC}, 6-8$ & 302.50 & 218.2 & 21.1 & 0.03 & 50 & 222.0 & 22.5 & 0.03 & $\mathrm{~N}$ & 2 & 2 \\
\hline $25, \mathrm{CC}, 15-17$ & 312.00 & 198.0 & 31.9 & 0.04 & 50 & 256.5 & 11.6 & 0.07 & $\mathrm{~N}$ & 3 & 3 \\
\hline $26, \mathrm{CC}, 12-14$ & 321.50 & 338.5 & 63.5 & 0.07 & 50 & 277.4 & 63.7 & 0.05 & $\mathrm{~N}$ & 2 & 3 \\
\hline $29-1,68-70$ & 341.19 & 50.3 & 32.3 & 0.06 & 50 & 19.3 & 24.6 & 0.07 & $\mathrm{~N}$ & 2 & 3 \\
\hline $29-2,9-11$ & 342.10 & 100.8 & 43.8 & 0.34 & 50 & 105.8 & 47.0 & 0.32 & $\mathrm{~N}$ & 2 & 2 \\
\hline $30-1,111-113$ & 351.12 & 36.3 & -36.5 & 0.06 & 50 & 38.3 & 0.4 & 0.08 & $\mathrm{~N}$ & 3 & 2 \\
\hline $31-1,100-102$ & 360.51 & 96.6 & -5.5 & 0.25 & 50 & 74.7 & 51.1 & 0.08 & $\mathrm{~N}$ & 2 & 3 \\
\hline $32-2,52-54$ & 371.03 & 100.1 & 48.6 & 0.31 & 50 & 81.6 & 47.3 & 0.44 & $\mathrm{~N}$ & 2 & 2 \\
\hline $35-1,6-8$ & 397.57 & 105.3 & 33.6 & 0.51 & 50 & 117.5 & 26.4 & 0.37 & $\mathrm{~N}$ & 2 & 2 \\
\hline $35-3,101-103$ & 401.52 & 173.0 & 72.3 & 0.24 & 100 & 180.8 & 69.9 & 0.15 & $\mathrm{~N}$ & 1 & 1 \\
\hline $35, \mathrm{CC}$ & 407.00 & 187.3 & 65.7 & 0.11 & 50 & 314.5 & 20.3 & 0.07 & $\mathrm{~N}$ & 2 & 3 \\
\hline $36-1,31-33$ & 407.32 & 346.1 & 16.0 & 0.83 & 100 & 349.1 & 14.6 & 0.78 & $\mathrm{~N}$ & 1 & 1 \\
\hline $36-2,79-81$ & 409.30 & 213.2 & 3.8 & 0.02 & 100 & 329.1 & 21.4 & 0.03 & $\mathrm{~N}$ & 2 & 3 \\
\hline $37-1,47-49$ & 416.98 & 113.5 & 65.1 & 0.04 & 50 & 201.6 & 85.6 & 0.07 & $\mathrm{~N}$ & 3 & 3 \\
\hline $37-2,103-105$ & 419.04 & 268.8 & -29.3 & 0.18 & 100 & 270.2 & -43.1 & 0.13 & $\mathrm{R}$ & 1 & 2 \\
\hline $37-3,80-82$ & 420.31 & 357.4 & 76.6 & 0.12 & 50 & 253.0 & 76.3 & 0.08 & $\mathrm{~N}$ & 2 & 3 \\
\hline $37-4,101-103$ & 422.02 & 331.8 & -44.9 & 0.02 & 50 & 43.7 & -76.3 & 0.02 & $\mathrm{R}$ & 3 & 3 \\
\hline $38-1,90-92$ & 426.91 & 133.7 & 57.1 & 0.05 & 50 & 33.9 & 64.9 & 0.10 & $\mathrm{~N}$ & 2 & 3 \\
\hline $39-1,40-42$ & 435.91 & 64.7 & 63.1 & 0.44 & 50 & 79.5 & 51.2 & 0.25 & $\mathrm{~N}$ & 1 & 2 \\
\hline $39-2,69-71$ & 437.70 & 17.2 & 40.9 & 0.02 & 50 & 271.8 & 51.9 & 0.12 & $\mathrm{~N}$ & 2 & 3 \\
\hline $39-3,63-65$ & 439.14 & 343.1 & 70.6 & 0.16 & 50 & 297.7 & 40.0 & 0.16 & $\mathrm{~N}$ & 2 & 3 \\
\hline $40-1,25-27$ & 445.26 & 0.9 & 68.1 & 0.12 & 50 & 79.0 & -37.3 & 0.16 & $\mathrm{R}$ & 2 & 3 \\
\hline $40-1,65-68$ & 445.66 & 346.3 & 39.5 & 0.12 & 50 & 143.0 & 74.4 & 0.16 & $\mathrm{~N}$ & 2 & 3 \\
\hline $40-2,62-64$ & 447.13 & 68.5 & -44.5 & 0.07 & 50 & 335.1 & 40.5 & 0.05 & $\mathrm{~N}$ & 2 & 3 \\
\hline $43-1,80-82$ & 474.31 & 316.9 & 29.6 & 0.08 & 50 & 348.3 & 21.7 & 0.04 & $\mathrm{~N}$ & 2 & 3 \\
\hline $43-2,73-75$ & 475.74 & 17.3 & 70.6 & 0.08 & 50 & 2.6 & 83.4 & 0.08 & $\mathrm{~N}$ & 2 & 2 \\
\hline $43-3,75-77$ & 477.26 & 202.2 & 45.6 & 1.40 & 100 & 208.7 & 44.1 & 1.36 & $\mathrm{~N}$ & 1 & 2 \\
\hline $43-4,68-70$ & 478.69 & 198.1 & 36.3 & 7.62 & 100 & 196.8 & 36.7 & 6.96 & $\mathrm{~N}$ & 1 & 2 \\
\hline $43-5,86-88$ & 480.37 & 219.0 & 15.2 & 0.20 & 300 & 206.8 & -39.8 & 0.42 & $\mathrm{R}$ & 1 & 2 \\
\hline $44-1,68-71$ & 483.70 & 170.6 & 58.7 & 1.40 & 300 & 174.5 & 49.2 & 0.71 & $\mathrm{~N}$ & 1 & 2 \\
\hline $45-1,49-51$ & 493.00 & 17.6 & 50.3 & 1.48 & 300 & 69.2 & 61.9 & 0.23 & $\mathrm{~N}$ & 1 & 3 \\
\hline $45-2,92-94$ & 494.93 & 305.8 & 69.3 & 8.65 & 300 & 121.9 & -34.2 & 2.26 & $\mathrm{R}$ & 1 & 3 \\
\hline $45-3,112-114$ & 496.63 & 159.4 & 75.1 & 12.46 & 150 & 179.2 & 64.1 & 5.07 & $\mathrm{~N}$ & 1 & 2 \\
\hline $45-4,76-78$ & 497.77 & 256.5 & 64.4 & 14.01 & 150 & 252.2 & 59.4 & 3.91 & $\mathrm{~N}$ & 1 & 2 \\
\hline $45-5,20-22$ & 498.71 & 115.2 & 70.3 & 8.51 & 150 & 262.7 & -26.9 & 4.04 & $\mathrm{R}$ & 1 & 2 \\
\hline $46-4,109-111$ & 507.60 & 4.1 & -2.8 & 3.84 & 300 & 43.5 & 41.0 & 1.93 & $\mathrm{~N}$ & 1 & 2 \\
\hline $46-5,5-7$ & 508.06 & 287.6 & 50.4 & 6.60 & 300 & 300.2 & 32.0 & 1.30 & $\mathrm{~N}$ & 1 & 2 \\
\hline $46, \mathrm{CC}$ & 511.50 & 82.4 & -58.9 & 4.24 & 150 & 80.7 & -52.2 & 1.41 & $\mathrm{R}$ & 1 & 2 \\
\hline $47-1,15-17$ & 511.66 & 19.1 & 79.1 & 5.31 & 300 & 33.0 & -35.5 & 1.18 & $\mathrm{R}$ & 1 & 2 \\
\hline $47-6,143-145$ & 520.44 & 303.0 & 64.2 & 9.17 & 300 & 166.5 & -23.7 & 0.79 & $\mathrm{R}$ & 1 & 2 \\
\hline $47-7,26-27$ & 520.76 & 21.8 & 50.4 & 5.31 & 150 & 323.5 & -22.7 & 1.64 & $\mathrm{R}$ & 1 & 2 \\
\hline $48-2,144-145$ & 523.94 & 117.8 & 64.2 & 0.52 & 150 & 113.3 & 81.5 & 0.28 & $\mathrm{~N}$ & 1 & 2 \\
\hline $49-1,6-7$ & 530.56 & 199.5 & -0.2 & 1.67 & 300 & 185.2 & 9.7 & 0.16 & $\mathrm{~N}$ ? & 2 & 2 \\
\hline $49-1,134-136$ & 531.85 & 298.3 & 50.4 & 0.22 & 150 & 274.0 & 50.8 & 0.18 & $\mathrm{~N}$ & 1 & 2 \\
\hline $49-2,42-44$ & 532.43 & 240.4 & 2.2 & 0.08 & 150 & 185.8 & -3.4 & 0.03 & $?$ & 4 & 4 \\
\hline $49-2,129-131$ & 533.30 & 18.4 & 64.4 & 0.15 & 150 & 54.8 & 3.1 & 0.06 & $?$ & 4 & 4 \\
\hline $49-3,79-81$ & 534.30 & 4.1 & -21.5 & 0.07 & 150 & 9.3 & -0.8 & 0.07 & $?$ & 4 & 4 \\
\hline $49-3,134-135$ & 535.64 & 74.7 & 67.2 & 0.09 & 200 & 257.3 & 17.7 & 0.02 & $?$ & 4 & 4 \\
\hline $49-4,74-86$ & 535.75 & 63.8 & 57.8 & 0.15 & 200 & 147.7 & 58.0 & 0.08 & $N ?$ & 3 & 4 \\
\hline $50-4,98-100$ & 545.49 & 200.1 & 75.4 & 0.04 & 100 & 240.2 & 63.1 & 0.09 & $\mathrm{~N}$ ? & 3 & 4 \\
\hline $51-1,6-8$ & 549.57 & 105.0 & 37.5 & 0.07 & 100 & 114.0 & -6.2 & 0.05 & $?$ & 4 & 4 \\
\hline $51-1,99-101$ & 550.50 & 216.4 & 42.2 & 0.13 & 300 & 190.7 & 43.1 & 0.11 & $\mathrm{~N}$ & 2 & 3 \\
\hline $51-2,31-33$ & 551.32 & 87.0 & 9.8 & 0.05 & 200 & 3.9 & -43.2 & 0.03 & $?$ & 4 & 4 \\
\hline $51-2,103-105$ & 552.04 & 44.5 & 86.3 & 0.16 & 100 & 295.4 & 71.6 & 0.19 & $\mathrm{~N}$ ? & 3 & 4 \\
\hline $51-3,6-8$ & 552.57 & 351.6 & 32.1 & 0.08 & 200 & 295.6 & 50.4 & 0.04 & $?$ & 4 & 4 \\
\hline $51-3,126-128$ & 553.77 & 59.8 & 50.8 & 0.12 & 200 & 77.4 & 50.6 & 0.14 & $\mathrm{~N}$ & 3 & 4 \\
\hline
\end{tabular}


TABLE 1 - Continued

\begin{tabular}{|c|c|c|c|c|c|c|c|c|c|c|c|}
\hline \multirow{2}{*}{$\begin{array}{c}\text { Sample } \\
\text { (Interval in } \mathrm{cm} \text { ) }\end{array}$} & \multirow[b]{2}{*}{ Depth } & \multirow[b]{2}{*}{ Dec. } & \multirow{2}{*}{$\begin{array}{l}\text { NRM } \\
\text { Inc. }\end{array}$} & \multirow[b]{2}{*}{ Int. } & \multirow{2}{*}{$\begin{array}{l}\text { Demag. } \\
\text { Field }\end{array}$} & \multicolumn{3}{|c|}{ After Demagnetization } & \multirow[b]{2}{*}{ Polarity } & \multicolumn{2}{|c|}{ Category $^{\mathrm{a}}$} \\
\hline & & & & & & Dec. & Inc. & Int. & & Polarity & Direction \\
\hline $51-4,23-25$ & 554.24 & 229.5 & 72.4 & 0.20 & 300 & 178.8 & 60.5 & 0.06 & $\mathrm{~N}$ & 3 & 4 \\
\hline $51-4,97-99$ & 554.98 & 187.4 & 57.4 & 0.08 & 100 & 190.0 & 53.1 & 0.04 & $\mathrm{~N}$ & 3 & 3 \\
\hline $51-5,16-18$ & 555.67 & 162.8 & 40.3 & 0.16 & 300 & 178.6 & 55.2 & 0.07 & $\mathrm{~N}$ & 3 & 3 \\
\hline $51-5,105-107$ & 556.56 & 97.0 & 59.1 & 0.35 & 300 & 170.2 & 58.4 & 0.06 & $\mathrm{~N}$ & 3 & 4 \\
\hline $51-6,30-32$ & 557.31 & 261.4 & 63.3 & 0.17 & 300 & 245.6 & 76.7 & 0.09 & $\mathrm{~N}$ & 3 & 3 \\
\hline $51-6,141-143$ & 558.42 & 254.5 & 68.2 & 0.19 & 300 & 138.5 & 13.5 & 0.12 & $\mathrm{~N}$ ? & $3-4$ & 4 \\
\hline $51-7,14-16$ & 558.65 & 272.1 & 51.4 & 0.20 & 300 & 311.1 & 52.4 & 0.08 & $\mathrm{~N}$ & 2 & 3 \\
\hline $52-1,7-9$ & 559.08 & 162.3 & 67.0 & 0.11 & 300 & 85.7 & -22.0 & 0.06 & $\mathrm{R}$ & 3 & 4 \\
\hline $52-1,109-111$ & 560.10 & 260.5 & 70.2 & 0.20 & 300 & 257.5 & 42.1 & 0.06 & $\mathrm{~N}$ & 3 & 2 \\
\hline $52-2,2-4$ & 560.53 & 67.9 & 68.3 & 0.22 & 300 & 308.3 & 66.1 & 0.12 & $\mathrm{~N}$ & 2 & 3 \\
\hline $52-2,128-130$ & 561.79 & 109.2 & 70.3 & 7.39 & 300 & 109.0 & 67.3 & 0.55 & $\mathrm{~N}$ & 1 & 2 \\
\hline $52-3,5-7$ & 562.06 & 101.7 & 69.8 & 0.81 & 100 & 116.1 & 68.1 & 0.54 & $\mathrm{~N}$ & 1 & 2 \\
\hline $52-3,102-104$ & 563.03 & 146.0 & 62.1 & 0.51 & 300 & 200.1 & 46.7 & 0.18 & $\mathrm{~N}$ & 2 & 3 \\
\hline $52-4,8-10$ & 563.59 & 251.0 & 77.0 & 0.20 & 300 & 196.3 & 63.2 & 0.18 & $\mathrm{~N}$ & 2 & 4 \\
\hline $52-4,88-90$ & 564.39 & 0.2 & 57.8 & 2.99 & 300 & 28.8 & 45.2 & 1.45 & $\mathrm{~N}$ & 2 & 2 \\
\hline $52-5,48-50$ & 565.49 & 256.9 & 73.9 & 0.16 & 100 & 211.6 & 58.5 & 0.19 & $\mathrm{~N}$ & 2 & 3 \\
\hline $52-5,93-95$ & 565.94 & 284.2 & 63.6 & 0.47 & 300 & 312.5 & 47.8 & 0.24 & $\mathrm{~N}$ & 2 & 3 \\
\hline $53-1,13-15$ & 568.64 & 98.3 & 70.2 & 3.32 & 300 & 133.4 & 65.9 & 1.75 & $\mathrm{~N}$ & 2 & 2 \\
\hline $53-1,144-146$ & 569.95 & 167.5 & 12.3 & 5.40 & 300 & 160.3 & -0.8 & 3.97 & $\mathrm{R}$ ? & 1 & 1 \\
\hline $54-1,106-108$ & 579.07 & 352.2 & 52.0 & 17.35 & 300 & 58.9 & -14.0 & 3.00 & $\mathrm{R}$ & 1 & 2 \\
\hline $54-2,2-4$ & 579.53 & 158.6 & 48.9 & 16.26 & 300 & 158.6 & -43.4 & 1.78 & $\mathrm{R}$ & 1 & 1 \\
\hline $54-2,121-123$ & 580.72 & 91.9 & 63.3 & 21.67 & 300 & 154.9 & 38.6 & 1.92 & $\mathrm{~N}$ & 2 & 3 \\
\hline $54-3,23-25$ & 581.24 & 135.4 & 50.8 & 13.45 & 700 & 131.1 & -20.2 & 1.07 & $\mathrm{R}$ ? & 3 & 4 \\
\hline $54-3,110-112$ & 582.11 & 14.8 & 45.1 & 14.39 & 700 & 353.6 & -1.7 & 1.92 & $\mathrm{R}$ ? & 3 & 2 \\
\hline $55-2,44-46$ & 589.45 & 129.4 & 68.1 & 0.15 & 300 & 35.2 & 43.1 & 0.08 & $\mathrm{~N}$ & 2 & 4 \\
\hline $56, \mathrm{CC}$ & 606.50 & 178.9 & 35.0 & 4.85 & 700 & 158.0 & -4.8 & 2.45 & $\mathrm{R}$ ? & 3 & 2 \\
\hline $57-1,148-150$ & 607.99 & 311.5 & 80.6 & 13.51 & 300 & 18.1 & 36.6 & 2.62 & $\mathrm{~N}$ & 2 & 3 \\
\hline $59-1,23-25$ & 625.74 & 232.5 & 56.7 & 13.61 & 300 & 103.4 & -42.0 & 2.54 & $\mathrm{R}$ & 1 & 3 \\
\hline $60-6,147-149$ & 643.98 & 157.2 & 66.4 & 0.38 & 300 & 240.8 & 53.3 & 0.12 & $\mathrm{~N}$ & 1 & 3 \\
\hline $61, \mathrm{CC}$ & 654.00 & 75.9 & 67.5 & 46.34 & 300 & 264.8 & -40.8 & 2.56 & $\mathrm{R}$ & 1 & 1 \\
\hline $62-1,75-77$ & 654.76 & 74.3 & 26.2 & 0.15 & 300 & 86.9 & 56.8 & 0.08 & $\mathrm{~N}$ & 1 & 2 \\
\hline $62-2,128-130$ & 656.79 & 107.1 & 69.9 & 0.26 & 300 & 96.6 & 49.4 & 0.15 & $\mathrm{~N}$ & 1 & 2 \\
\hline $62-3,22-24$ & 657.23 & 121.7 & 75.1 & 0.22 & 500 & 173.1 & -28.8 & 0.09 & $\mathrm{R}$ & 2 & 3 \\
\hline $62-3,105-107$ & 658.06 & 139.6 & -71.9 & 0.16 & 300 & 93.7 & -61.7 & 0.11 & $\mathrm{R}$ & 1 & 2 \\
\hline $62-3,142-144$ & 658.43 & 83.8 & 48.3 & 0.20 & 300 & 273.7 & 52.5 & 0.17 & $\mathrm{~N}$ & 1 & 2 \\
\hline $62-4,1-3$ & 658.52 & 131.6 & 45.1 & 0.25 & 300 & 158.4 & 41.5 & 0.10 & $\mathrm{~N}$ & 1 & 2 \\
\hline $62-4,134-139$ & 659.90 & 218.7 & 47.4 & 0.16 & 300 & 210.9 & 12.3 & 0.05 & $\mathrm{~N}$ & 3 & 4 \\
\hline $62-5,50-52$ & 660.51 & 264.5 & 36.6 & 0.21 & 300 & 261.9 & 58.1 & 0.09 & $\mathrm{~N}$ & 1 & 2 \\
\hline $62-5,128-130$ & 661.29 & 313.4 & 54.1 & 0.25 & 300 & 288.6 & 35.9 & 0.11 & $\mathrm{~N}$ & 1 & 2 \\
\hline $62, \mathrm{CC}$ & 663.50 & 292.5 & -46.4 & 0.20 & 300 & 267.1 & -43.2 & 0.10 & $\mathrm{R}$ & 1 & 2 \\
\hline $63-1,42-44$ & 663.93 & 98.1 & 69.6 & 0.08 & 500 & 164.9 & 48.1 & 0.11 & $\mathrm{~N}$ & 3 & 3 \\
\hline $63-1,130-132$ & 664.81 & 2.2 & 45.2 & 0.12 & 500 & 319.4 & 79.9 & 0.09 & $\mathrm{~N}$ & 2 & 4 \\
\hline $63-2,1-3$ & 665.02 & 149.2 & 48.9 & 0.36 & 300 & 189.0 & 42.6 & 0.09 & $\mathrm{~N}$ & 1 & 3 \\
\hline $63-2,107-109$ & 666.08 & 146.7 & 55.2 & 0.14 & 300 & 282.3 & -59.5 & 0.04 & $\mathrm{R}$ & 1 & 4 \\
\hline $63-3,1-3$ & 666.52 & 85.5 & -10.4 & 0.13 & 500 & 145.2 & 36.9 & 0.11 & $\mathrm{~N}$ & 2 & 4 \\
\hline $63-3,128-130$ & 667.79 & 11.6 & 24.4 & 0.17 & 300 & 44.6 & 34.1 & 0.09 & $\mathrm{~N}$ & 2 & 4 \\
\hline $63-4,34-36$ & 668.35 & 325.5 & 40.2 & 0.16 & 300 & 319.0 & 35.2 & 0.12 & $\mathrm{~N}$ & 1 & 3 \\
\hline $63-4,120-122$ & 669.21 & 334.8 & -29.4 & 0.06 & 100 & 243.9 & -22.4 & 0.04 & $\mathrm{R}$ & 1 & 2 \\
\hline $64-1,28-30$ & 673.29 & 34.2 & 51.9 & 0.46 & 300 & 47.9 & 53.2 & 0.21 & $\mathrm{~N}$ & 1 & 2 \\
\hline $64-1,146-148$ & 674.47 & 42.1 & 64.2 & 0.22 & 100 & 45.5 & 68.4 & 0.17 & $\mathrm{~N}$ & 1 & 2 \\
\hline $64-2,61-63$ & 675.12 & 17.8 & 44.5 & 0.29 & 100 & 2.8 & 27.0 & 0.26 & $\mathrm{~N}$ & 1 & 2 \\
\hline $64-2,147-149$ & 675.98 & 117.2 & 54.1 & 0.36 & 300 & 121.0 & 66.0 & 0.14 & $\mathrm{~N}$ & 1 & 2 \\
\hline $64-3,47-49$ & 676.48 & 310.2 & 47.2 & 0.34 & 100 & 316.3 & 44.6 & 0.26 & $\mathrm{~N}$ & 1 & 2 \\
\hline $64-3,112-114$ & 677.13 & 271.0 & 52.0 & 0.17 & 100 & 276.8 & 50.4 & 0.15 & $\mathrm{~N}$ & 1 & 2 \\
\hline $64-4,40-42$ & 677.91 & 125.9 & 46.6 & 0.15 & 300 & 114.0 & 64.1 & 0.10 & $\mathrm{~N}$ & 1 & 2 \\
\hline $64-4,148-150$ & 678.99 & 55.8 & 52.0 & 0.35 & 100 & 56.8 & 54.9 & 0.26 & $\mathrm{~N}$ & 1 & 2 \\
\hline $64-5,78-80$ & 679.79 & 72.3 & 53.9 & 0.26 & 100 & 69.4 & 58.4 & 0.23 & $\mathrm{~N}$ & 1 & 2 \\
\hline $65-1,37-39$ & 682.88 & 145.5 & 58.7 & 0.26 & 300 & 165.6 & 48.9 & 0.15 & $\mathrm{~N}$ & 1 & 2 \\
\hline $65-1,114-116$ & 683.65 & 270.4 & 60.6 & 0.35 & 100 & 277.3 & 58.4 & 0.26 & $\mathrm{~N}$ & 1 & 2 \\
\hline $65, \mathrm{CC}$ & 685.00 & 209.1 & 59.2 & 0.31 & 300 & 234.5 & 26.7 & 0.16 & $\mathrm{~N}$ & 1 & 3 \\
\hline $66-1,34-36$ & 692.35 & 255.8 & 84.8 & 0.24 & 300 & 165.9 & 66.0 & 0.09 & $\mathrm{~N}$ & 1 & 3 \\
\hline $66-1,131-133$ & 693.32 & 93.6 & 59.2 & 0.41 & 300 & 80.4 & 50.7 & 0.26 & $\mathrm{~N}$ & 1 & 2 \\
\hline $66-2,24-26$ & 693.75 & 270.8 & 54.8 & 0.22 & 300 & 276.7 & 37.9 & 0.11 & $\mathrm{~N}$ & 1 & 2 \\
\hline $66-2,125-127$ & 694.76 & 195.9 & 18.0 & 0.22 & 300 & 165.2 & 20.3 & 0.09 & $\mathrm{~N}$ & 2 & 3 \\
\hline $66-3,1-3$ & 695.02 & 325.6 & 65.9 & 0.19 & 300 & 259.6 & 58.4 & 0.10 & $\mathrm{~N}$ & 1 & 2 \\
\hline $66-3,106-108$ & 696.07 & 360.0 & 47.0 & 0.25 & 300 & 25.6 & 59.0 & 0.19 & $\mathrm{~N}$ & 1 & 2 \\
\hline $66-4,66-68$ & 697.17 & 298.8 & 58.7 & 0.27 & 300 & 256.1 & 44.9 & 0.12 & $\mathrm{~N}$ & 1 & 2 \\
\hline
\end{tabular}


TABLE 1 - Continued

\begin{tabular}{|c|c|c|c|c|c|c|c|c|c|c|c|}
\hline \multirow{2}{*}{$\begin{array}{c}\text { Sample } \\
\text { (Interval in cm) }\end{array}$} & \multirow[b]{2}{*}{ Depth } & \multirow[b]{2}{*}{ Dec. } & \multirow{2}{*}{$\begin{array}{l}\text { NRM } \\
\text { Inc. }\end{array}$} & \multirow[b]{2}{*}{ Int. } & \multirow{2}{*}{$\begin{array}{l}\text { Demag. } \\
\text { Field }\end{array}$} & \multicolumn{3}{|c|}{ After Demagnetization } & \multirow[b]{2}{*}{ Polarity } & \multicolumn{2}{|c|}{ Category $^{\mathrm{a}}$} \\
\hline & & & & & & Dec. & Inc. & Int. & & Polarity & Direction \\
\hline $67, \mathrm{CC}$ & 711.00 & 108.1 & 54.1 & 0.21 & 300 & 163.5 & 71.9 & 0.12 & $\mathrm{~N}$ & 1 & 3 \\
\hline $68-1,75-77$ & 711.76 & 150.7 & 47.6 & 0.29 & 300 & 178.5 & 9.2 & 0.07 & $\mathrm{~N}$ & 3 & 3 \\
\hline $68-2,19-21$ & 712.70 & 222.2 & 51.0 & 0.19 & 300 & 225.0 & 16.0 & 0.08 & $\mathrm{~N}$ & 3 & 3 \\
\hline $68-2,92-94$ & 713.43 & 79.1 & 52.5 & 0.20 & 100 & 77.1 & 45.9 & 0.13 & $\mathrm{~N}$ & 2 & 3 \\
\hline $68-3,5-7$ & 714.06 & 45.9 & 47.4 & 0.23 & 500 & 41.2 & 63.5 & 0.07 & $\mathrm{~N}$ & 1 & 2 \\
\hline $69-1,21-23$ & 720.72 & 73.6 & 63.7 & 0.43 & 300 & 60.8 & 58.3 & 0.26 & $\mathrm{~N}$ & 1 & 2 \\
\hline $69, \mathrm{CC}$ & 730.00 & 345.2 & 17.7 & 0.07 & 300 & 257.8 & 16.1 & 0.05 & $\mathrm{~N}$ & 3 & 3 \\
\hline $70-2,101-103$ & 732.52 & 326.6 & 63.6 & 0.22 & 300 & 331.5 & 44.3 & 0.06 & $\mathrm{~N}$ & 2 & 3 \\
\hline $71-1,20-22$ & 739.71 & 253.0 & 32.8 & 0.17 & 300 & 217.7 & 62.0 & 0.08 & $\mathrm{~N}$ & 2 & 3 \\
\hline $71-1,137-139$ & 740.88 & 323.0 & 47.9 & 0.25 & 300 & 315.7 & 38.3 & 0.13 & $\mathrm{~N}$ & 2 & 3 \\
\hline $71, \mathrm{CC}$ & 749.00 & 83.6 & 60.9 & 0.31 & 300 & 85.7 & 41.6 & 0.14 & $\mathrm{~N}$ & 2 & 3 \\
\hline $72-3,59-61$ & 752.60 & 317.6 & 60.6 & 0.26 & 300 & 296.9 & 62.5 & 0.17 & $\mathrm{~N}$ & 1 & 2 \\
\hline $72-3,136-138$ & 753.37 & 348.0 & 65.2 & 0.27 & 300 & 311.1 & 59.3 & 0.15 & $\mathrm{~N}$ & 1 & 2 \\
\hline $72-4,34-36$ & 753.85 & 124.5 & 54.7 & 0.23 & 300 & 163.8 & 63.5 & 0.07 & $\mathrm{~N}$ & 1 & 3 \\
\hline $72-4,46-48$ & 753.97 & 209.9 & -43.6 & 0.29 & 300 & 230.2 & -26.6 & 0.16 & $\mathrm{R}$ & 1 & 2 \\
\hline $72-4,61-63$ & 754.12 & 3.1 & 86.8 & 0.11 & 150 & 239.9 & 66.6 & 0.19 & $\mathrm{~N}$ & 1 & 2 \\
\hline $74-1,11-13$ & 768.12 & 109.5 & 26.8 & 0.03 & 100 & 162.9 & 27.0 & 0.04 & $\mathrm{~N}$ & 1 & 3 \\
\hline
\end{tabular}

${ }^{a}$ These categories represent a subjective attempt to estimate the reliabilities of the paleomagnetic directions listed after A.F. demagnetization, in terms of their stabilities and behavior during incremental demagnetization. The results are assigned to categories 1 to 4 (the higher the category number, the lower the reliability), on the basis of both polarity and precision of remanence direction. All intensity values are $\mathrm{X} 10^{-6} \mathrm{G}$.

\begin{tabular}{|c|c|c|}
\hline Category & Polarity & Remanence Direction \\
\hline 1 & $\begin{array}{l}\text { Unambiguously assigned on } \\
\text { basis of stable end point de- } \\
\text { fined by more than one } \\
\text { demagnetization step }\end{array}$ & $\begin{array}{l}\text { Considered reliable } \\
\text { to at least } \pm 5^{\circ}\end{array}$ \\
\hline 2 & $\begin{array}{l}\text { Considered reliable, but on } \\
\text { basis of single demagnetiza- } \\
\text { tion step only }\end{array}$ & $\begin{array}{l}\text { Considered reliable } \\
\text { to at least } \pm 5^{\circ}\end{array}$ \\
\hline 3 & $\begin{array}{l}\text { Polarity questionable (e.g., } \\
\text { defined by very low inclina- } \\
\text { tion value) }\end{array}$ & $\begin{array}{l}\text { Generally unreliable (e.g., } \\
\text { intensity close to instrument } \\
\text { noise level), but some indi- } \\
\text { cation of stable end point } \\
\text { being present }\end{array}$ \\
\hline 4 & Unreliable & Unreliable \\
\hline
\end{tabular}

by van Hinte (1976). The magnetic polarity stratigraphy and biostratigraphic zones for Hole $400 \mathrm{~A}$ are compared with the Lower Cretaceous time scales of Larson and Hilde (1975) and of van Hinte (1976) (Hailwood et al., this volume). A conspicuous feature of this comparison is the absence at Hole $400 \mathrm{~A}$ of a prolonged late Aptian reversed interval corresponding to marine anomaly $M O$ ("Gatan" zone), but it is possible that this is due to the limited resolution of the polarity sequence at this site, caused by intermittent core recovery over the relevant interval. (See also discussion of Cretaceous paleomagnetic results from Hole 402A.)

\section{Magnetic Intensity and Susceptibility}

The downhole variation of low field susceptibility and NRM intensity at Hole 400A is presented in Figure 6, and a detailed comparison of these parameters with lithology for the lowermost 300 meters is shown in Figure 7. Both of these parameters are likely to reflect variations in type and amount of magnetic minerals within the sediments, but because NRM intensity may also be a function of other factors, such as geomagnetic field intensity at the time of deposition, and secondary magnetizations acquired during drilling or storage, susceptibility is a more useful index of magnetic mineral content. Preliminary thermomagnetic analyses of these sed- iments indicate that the dominant magnetic mineral present is titanomagnetite, and because this mineral appears to occur almost exclusively in the form of detrital grains, the magnetic susceptibility provides a sensitive index of variation in terrigenous components in these sediments.

Several conspicuous changes in both susceptibility and NRM intensity may be identified from Figures 6 and 7 . At the base of the hole, the first abrupt discontinuity occurs at a depth of 654 meters, at the top of the Aptian-Albian "black shale" sequence (Note: within the "black shales" samples were only taken from the sapropelic mudstones, and not from the interbedded marly nannofossil chalk layers). The susceptibility values for the sapropelic mudstones cluster around a mean of $\sim 10 \times 10^{-6} \mathrm{G} / \mathrm{Oe}$, but towards the top of this unit they progressively decrease by a factor of about 2 , to a mean value of $\sim 5 \times 10^{-6} \mathrm{G} / \mathrm{Oe}$, immediately beneath the upper Albian/Maestrichtian disconformity. This may reflect a progressive upward decrease in terrigenous sedimentary components throughout Cores 64 to 62 .

Within the range 654 to 570 meters the susceptibility and NRM intensity values are generally high and erratic throughout the sequence of brown and pink interbedded marly chalks and siliceous mudstones of late Paleocene and early Eocene age. This unit is separated from the overlying 

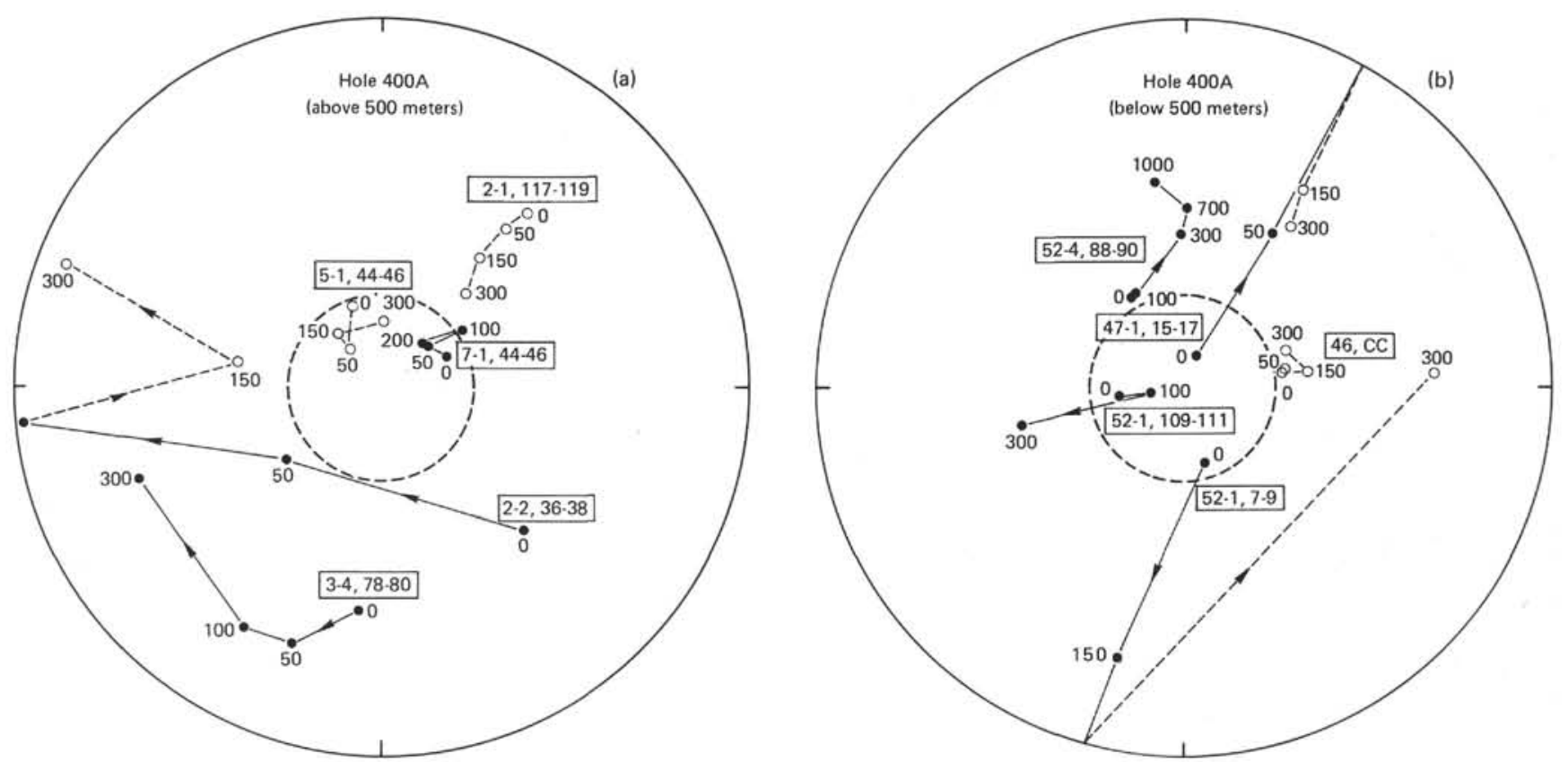

(c)
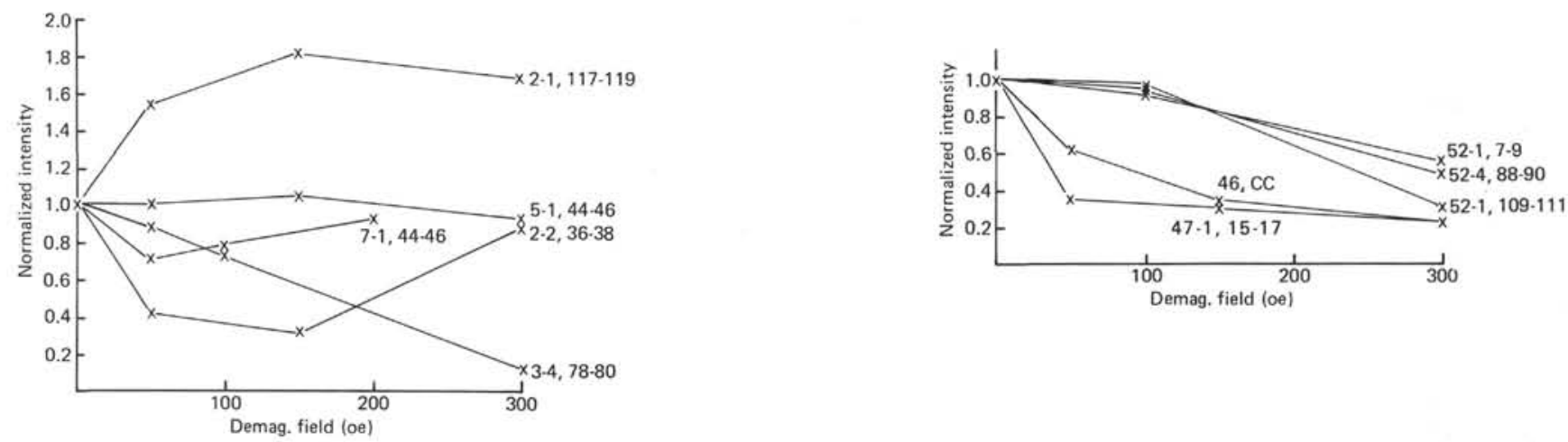

Figure 2. Examples of directional response to AF demagnetization of samples from (a) marls and nannochalk oozes above 500 meters sub-bottom, and (b) nannochalks and interbedded mudstones from below 500 meters sub-bottom at Hole 400A. Polar stereographic projections. Solid symbols, lower hemisphere (positive inclination); open symbols, upper hemisphere (negative inclination). Sample numbers enclosed in boxes, small numbers refer to peak applied alternating field value in Oersteds. (c) Plots of normalized intensity versus peak applied field for these samples.

Tertiary sediments by a fairly abrupt drop-off in magnetic susceptibility and NRM intensity within the depth range 570-580 meters, at the level of the early/middle Eocene boundary. The overlying boundaries at $\sim 520$ and 470 meters are also marked by changes in NRM intensity and/or mean susceptibility value (Figure 7 ), corresponding with lithological changes from dominant siliceous mudstones in the middle Eocene to marly nannofossil chalks in the Oligocene and nannofossil chalks in the early Miocene.

Changes in magnetic susceptibility closely follow changes in NRM intensity in these cores, but in general are less extreme. In both cases there is a high probability that they reflect variations in proportion of terrigenous magnetite due to changes in either source area, sediment supply rate, or rate of dissolution of non-magnetic (calcareous and siliceous) components. The geological implications of these variations are considered further in the discussion of paleomagnetic results from Site 401 .

\section{Paleomagnetically Determined Sedimentation Rates for Hole 400A}

The Pleistocene and Pliocene sediments cored at Hole 400A have yielded a detailed magnetic polarity stratigraphy, from which relatively precise sedimentation rates can be calculated. The Pleistocene to uppermost Miocene polarity sequence is plotted against the "standard" Neogene time scale (Hailwood et al., this volume) in Figure 5. The Matuyama/Gauss (2.4 m.y. B.P.) and Gauss/Gilbert (3.3 m.y. B.P.) epoch boundaries are well-defined at sub-bottom depths of 125 and 163 meters, respectively. Two short normal polarity intervals within the Matuyama reversed interval correlate with the Jaramillo and Olduvai events, and 


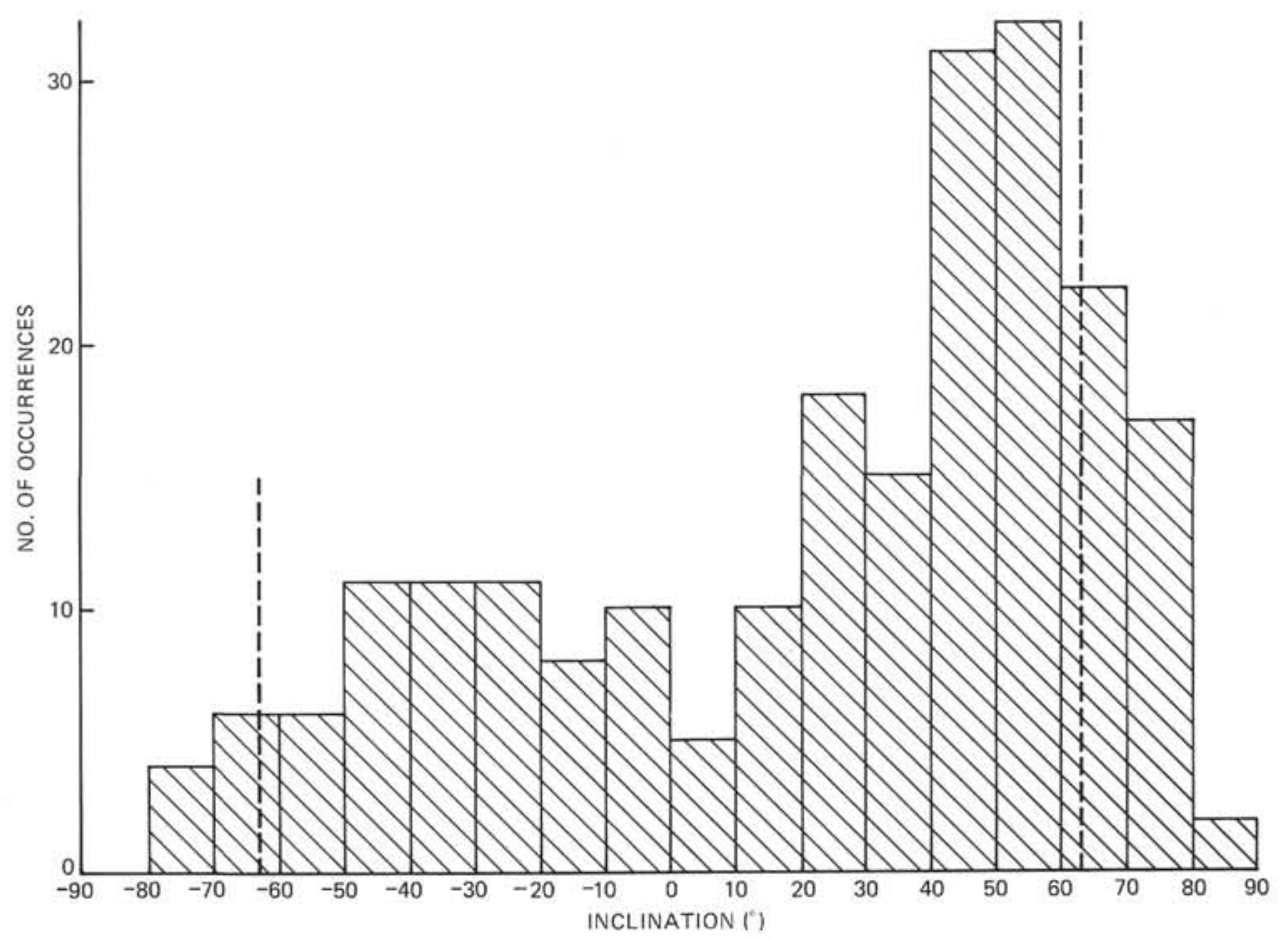

Figure 3. Histogram of inclination values for Hole $400 \mathrm{~A}$. Vertical dashed lines represent present-day theoretical axial geocentric dipole values.

two reverse polarity intervals within the Gauss normal interval with the Kaena and Mammoth events, respectively. The thin normal zone at 107 meters is based on a single sample of poor magnetic stability, but may possibly represent the "Reunion event,"' which appears to precede the Olduvai event in some areas.

Based on the above correlation, a mean accumulation rate of $46 \mathrm{~m} / \mathrm{m} . \mathrm{y}$. is derived for most of the Pliocene (4.2 to 1.7 m.y. B.P.) and, if the identification of the Jaramillo event is correct, a short hiatus, or a decrease in accumulation rate, is inferred within the interval 1.7 to 1.0 m.y. B.P. The mean accumulation rate increased to $82 \mathrm{~m} / \mathrm{m}$.y. during the last 1 million years.

A fairly complete magnetic polarity stratigraphy is also available at Hole 400A for the depth interval 180-270 meters, and may be correlated with epochs 4 to 7 , as indicated in Figure 5. According to this interpretation the sedimentation rate increased from a value of about $18 \mathrm{~m} / \mathrm{m}$.y. to $46 \mathrm{~m} / \mathrm{m}$.y. during the early Pliocene, at about the time of Gilbert event "b" (4.2 m.y. B.P.).

These sedimentation rate values are not corrected for compaction, and consequently part of the apparent series of increases in accumulation rates throughout the late Neogene at Hole $400 \mathrm{~A}$ may be attributed to such cause. However, the comparatively abrupt changes at depths of 205 meters and 95 meters suggest the additional influence of other factors. For example, they may be associated with the commencement of input of ice-rafted debris, at the onset of the Arctic glaciation, or increased detrital input resulting from the worldwide regression at the commencement of this glaciation.

\section{Site 401}

At Site 401 a single core of Pleistocene (NN 21) nannofossil ooze was recovered from immediately below the sediment/water interface, and continuous coring commenced at a sub-bottom depth of 84.5 meters. A total thickness of 88 meters of late to middle Eocene greenish gray nannofossil chalk oozes was cored, followed by 75 meters of Late Cretaceous to early Eocene yellowish brown marly nannofossil and foraminifer chalks. These in turn unconformably overlie pale orange to white shallow water coral reef deposits of Upper Jurassic age.

Two paleomagnetic samples per 1.5-meter core section were taken from the Pleistocene core, and one sample per section from the Eocene to Cretaceous cores.

\section{Paleomagnetic Results}

1) Pleistocene: The 10 samples from the Pleistocene core are strongly magnetized, with a high positive inclination which remains approximately constant during demagnetization to $300 \mathrm{Oe}$ (Table 2). The overall mean inclination after 300 -Oe treatment is $66 \pm 8^{\circ}$ for the eight most closely grouped magnetic vectors, and $59 \pm 15^{\circ}$ if the remaining two vectors with anomalously low inclination are included. In both cases the mean direction is not significantly different from the theoretical axial geocentric dipole value of $65^{\circ}$, for the latitude of Site 401 , and is consistent with the sediments having acquired their magnetization during the Brunhes epoch of normal magnetic polarity (i.e., the last 700,000 years). This is in accord with the NN 21 nannofossil zonation determined for this core.

2) Early Cenozoic: Because of the very weak magnetic moments, AF demagnetization of the greenish gray nannofossil oozes was limited to a maximum level of $150 \mathrm{Oe}$, and very few reliable polarity determinations were possible for these sediments (Table 2). However, the magnetic intensity of the underlying Late Cretaceous to early Eocene marly oozes was typically two orders of magnitude higher 


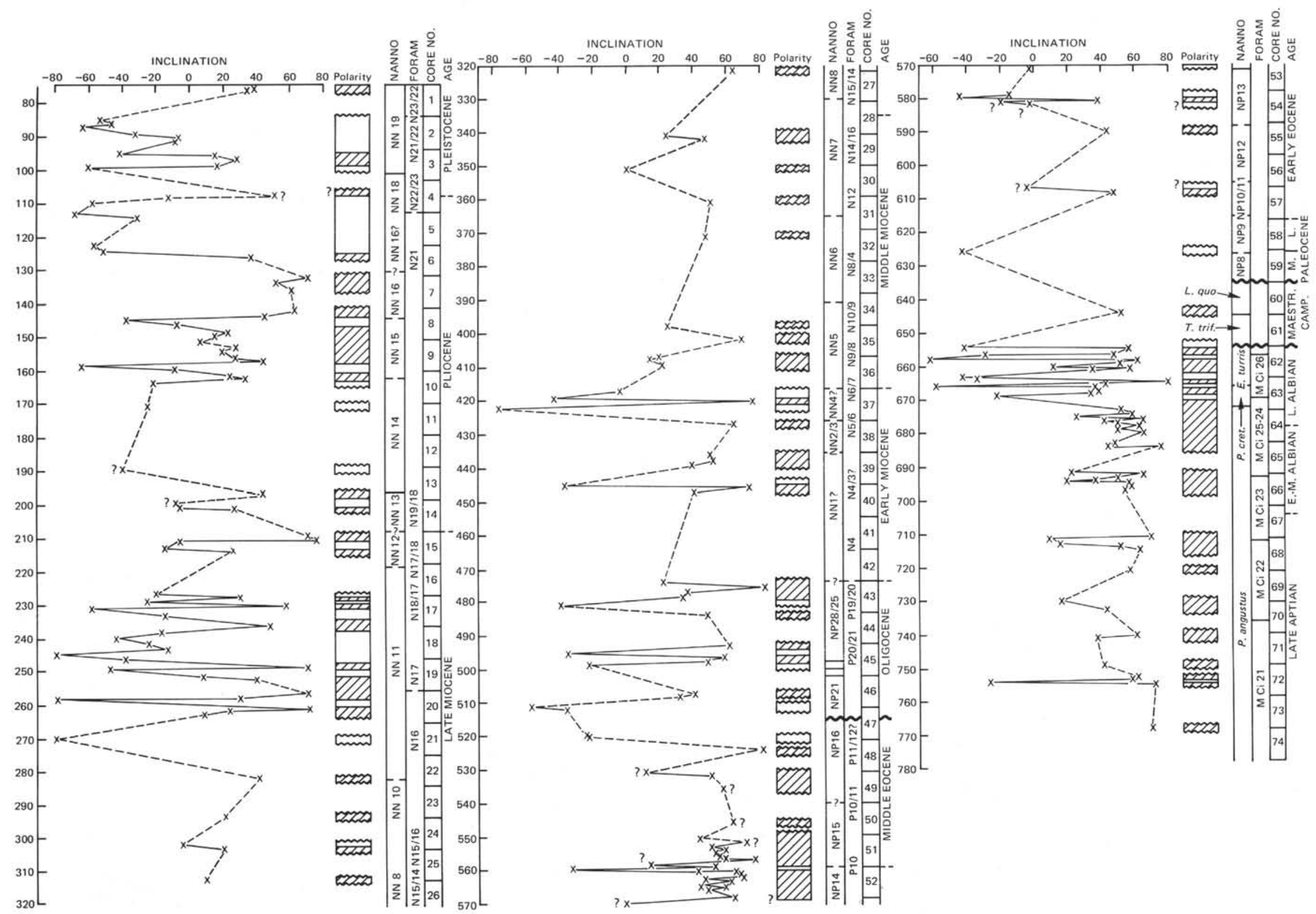

Figure 4. Downhole plot of magnetic inclination after optimum demagnetization, and inferred polarity reversal sequence for Hole 400A. Positions of nannofossil and foraminifer zones are also shown. Normal polarity shaded, reverse white. 

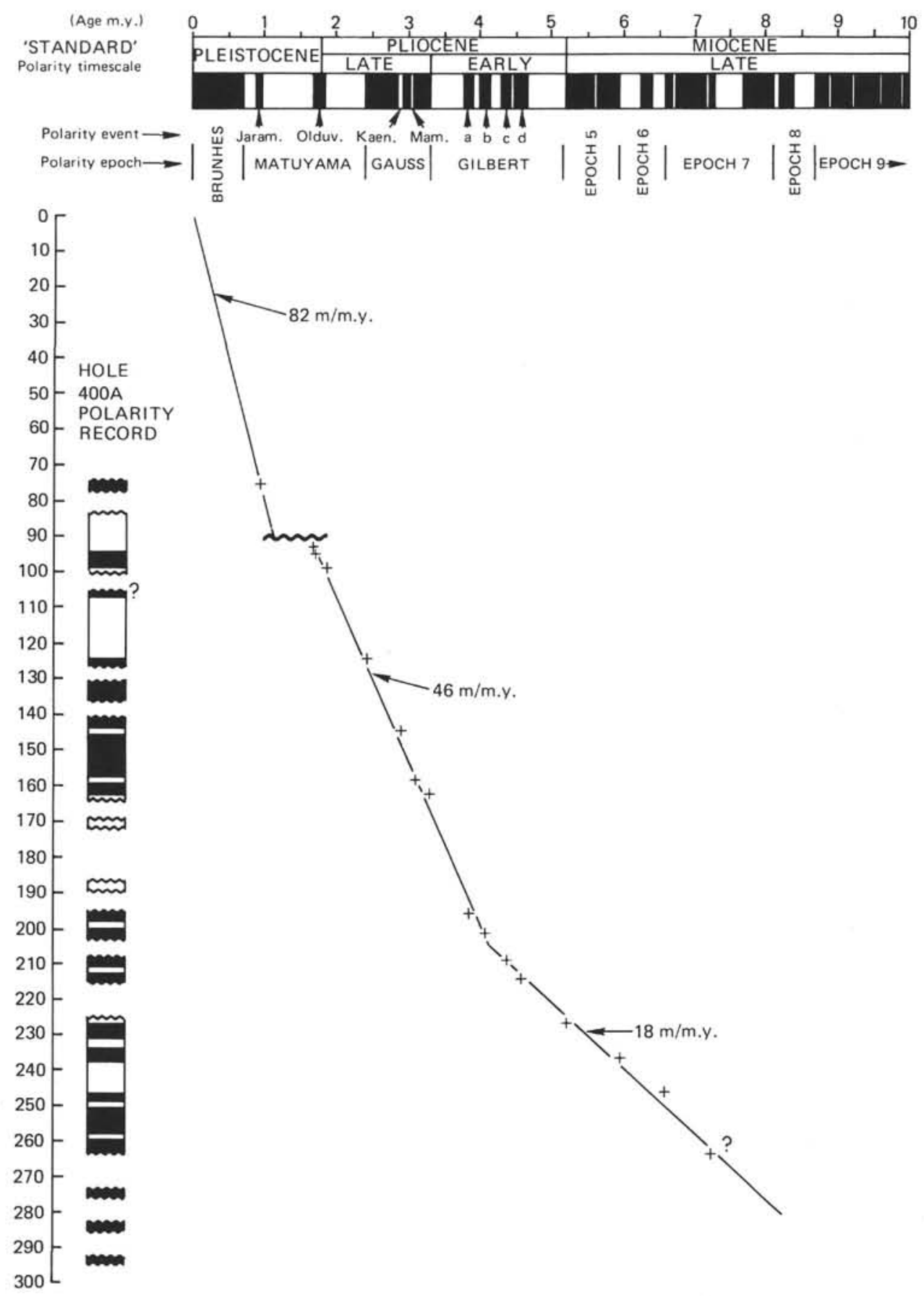

Figure 5. Proposed correlation between Pleistocene and late Miocene polarity sequence for Hole 400A, and standard polarity timescale. Correlation points are based on magnetic epoch boundaries and events for Epochs 1 to 4, and epoch boundaries alone for Epochs 5 to 7. Inferred mean accumulation rates are shown. Normal polarity shaded, reverse white.

than the instrument noise level, and demagnetization to a stable end point was usually possible. Reliable polarity determinations were achieved for a total of 20 early Cenozoic samples from this site, and the resultant polarity stratigraphy is shown in Figure 8. This diagram also shows the Paleocene to middle Eocene polarity reversal sequence for Hole $400 \mathrm{~A}$, together with the relevant portion of the revised Paleogene polarity time scale of Hailwood et al. (this volume). A conspicuous feature of the Hole $400 \mathrm{~A}$ polarity sequence is the long interval of normal polarity in Cores 51 and 52, which, on the basis of nannofossil zone determinations, is tentatively correlated with magnetic anomaly 22 . Two thin normal zones were identified in Cores 54 and 55, respectively, and are provisionally correlated with anomaly 23. At Site 401 a thin normal zone, based on a single sample near the top of Core 11 (Sample 401-11-12, 21-23 cm) is 


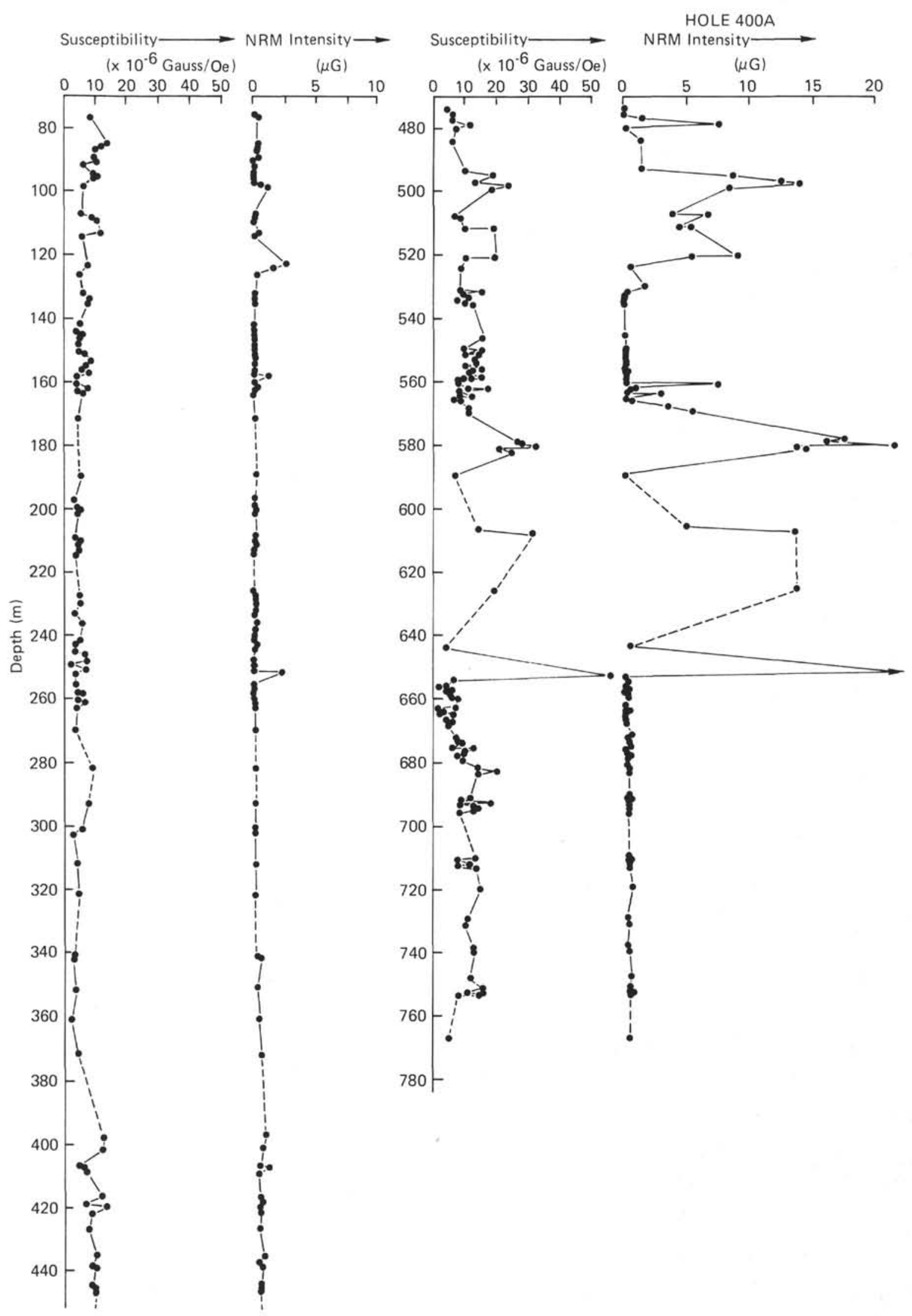

Figure 6. Downhole variation of low-field susceptibility and NRM intensity at Hole 400A. 


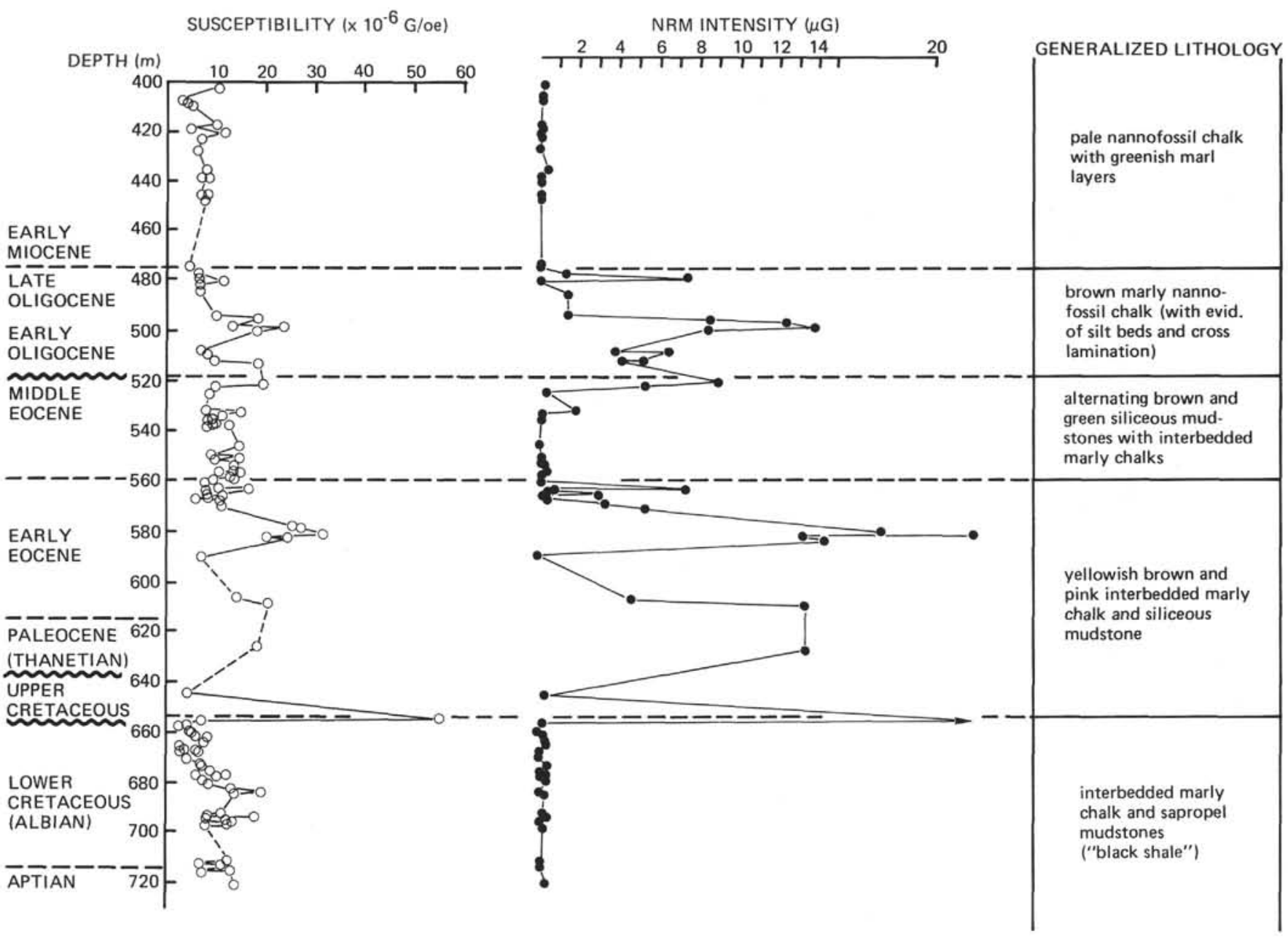

Figure 7. Correlation between magnetic susceptibility, NRM intensity, and lithology for Cretaceous to Miocene section from Hole $400 \mathrm{~A}$.

assigned to anomaly 22 , and a second thin normal zone near the top of Core 12 (Sample 401-12-2, 26-28 cm) to anomaly 23. At both Hole $400 \mathrm{~A}$ and Site 401 thin normal zones were identified near the top of nannofossil Zone NP 9, close to the Paleocene/Eocene boundary and may represent short normal polarity intervals within the long reverse interval preceding anomaly 24 .

\section{Magnetic Intensity and Susceptibility "Boundaries"}

It is significant that at both Hole $400 \mathrm{~A}$ and Site 401, an abrupt upward change from early Eocene yellow-brown marly chalks to mid Eocene green-gray chalks and siliceous mudstones correlates precisely with a sharp reduction in NRM intensity by a factor of 10 , and a reduction of magnetic susceptibility by a factor of 4 . At Hole $400 \mathrm{~A}$ this magnetic boundary occurs at a depth of 565 meters (Figure 7) and at Site 401 at a depth of 173 meters (Figure 9). In both cases the change is well defined stratigraphically, within the NP 14 nannofossil zone. Since the dominant magnetic mineral in these sediments is magnetite, most probably of detrital origin, this sharp decrease in susceptibility and NRM intensity appears to represent an abrupt reduction in the rate of supply of terrigenous material at the end of the early Eocene. A likely source of detrital magnetite in this region throughout the late Paleocene and early Eocene was erosion of the Hebridean (and possibly also the East Greenland) igneous province. The termination in supply of the terrigenous material at the end of the early Eocene may reflect the occurrence of an important oceanographic or tectonic event at this time, which resulted in a change in circulation patterns, sediment supply routes, or source areas within the Biscay region.

\section{Holes 402/402A}

Irregular core recovery from the 137 meters of Quaternary and late Tertiary sediment drilled at Site 402 limited the value of this site for magnetostratigraphic purposes, and consequently detailed paleomagnetic measurements have been restricted to the continuously cored offset Hole 402A. There, a short section of middle to late Eocene siliceous nannofossil ooze was cored within the interval 137 to 170 meters sub-bottom (Cores 1 to 4 ), followed by a sequence of Cretaceous shallow water bioclastic limestones and carbonaceous mudstones (Cores 5 to 35 ).

The Eocene oozes are weakly magnetized, and with the exception of one sample, the NRM intensities fall in the range 0.02 to $0.10 \mu \mathrm{G}$ (Figure 10). Consequently, $\mathrm{AF}$ demagnetization treatment was largely restricted to 25 and 50 
TABLE 2

Site 401: Paleomagnetic Results

\begin{tabular}{|c|c|c|c|c|c|c|c|c|c|c|c|}
\hline \multirow{2}{*}{$\begin{array}{c}\text { Sample } \\
\text { (Interval in } \mathrm{cm} \text { ) }\end{array}$} & \multirow[b]{2}{*}{ Depth } & \multirow[b]{2}{*}{ Dec. } & \multirow{2}{*}{$\begin{array}{l}\text { NRM } \\
\text { Inc. }\end{array}$} & \multirow[b]{2}{*}{ Int. } & \multirow{2}{*}{$\begin{array}{l}\text { Demag. } \\
\text { Field }\end{array}$} & \multicolumn{3}{|c|}{ After Demagnetization } & \multirow[b]{2}{*}{ Polarity } & Cat & gory ${ }^{a}$ \\
\hline & & & & & & Dec. & Inc. & Int. & & Polarity & Direction \\
\hline $1-1,68-70$ & 0.69 & 100.5 & 66.1 & 5.90 & 150 & 101.5 & 60.2 & 4.88 & $\mathrm{~N}$ & 1 & 1 \\
\hline $1-1,115-117$ & 1.16 & 215.0 & 48.5 & 5.20 & 150 & 242.8 & 47.6 & 3.62 & $\mathrm{~N}$ & 1 & 1 \\
\hline $1-2,58-60$ & 2.09 & 234.6 & 73.0 & 1.64 & 100 & 261.6 & 84.7 & 0.83 & $\mathrm{~N}$ & 1 & 2 \\
\hline $1-2,103-105$ & 2.54 & 310.8 & 59.0 & 4.20 & 100 & 311.0 & 55.9 & 3.32 & $\mathrm{~N}$ & 1 & 1 \\
\hline $1-3,12-14$ & 3.13 & 353.4 & 67.9 & 6.68 & 100 & 354.9 & 64.7 & 5.20 & $\mathrm{~N}$ & 1 & 1 \\
\hline $1-3,135-137$ & 4.36 & 83.9 & 70.9 & 8.92 & 100 & 87.7 & 70.7 & 7.51 & $\mathrm{~N}$ & 1 & 1 \\
\hline $1-4,68-70$ & 5.19 & 216.9 & 75.2 & 8.56 & 300 & 203.0 & 73.5 & 3.22 & $\mathrm{~N}$ & 1 & 2 \\
\hline $1-4,118-120$ & 5.69 & 238.3 & 65.4 & 8.60 & 100 & 244.5 & 67.5 & 6.48 & $\mathrm{~N}$ & 1 & 1 \\
\hline $1-5,47-49$ & 6.48 & 1.9 & 61.1 & 2.87 & 100 & 357.9 & 51.7 & 2.47 & $\mathrm{~N}$ & 1 & 2 \\
\hline $1-5,127-129$ & 7.28 & 227.0 & 55.5 & 2.47 & 100 & 218.0 & 53.3 & 2.13 & $\mathrm{~N}$ & 1 & 1 \\
\hline $2-1,49-51$ & 85.00 & 208.7 & 25.5 & 0.12 & 100 & 220.7 & 38.2 & 0.18 & N & 1 & 2 \\
\hline $3, \mathrm{CC}$ & 103.50 & 253.5 & 44.3 & 0.18 & 100 & 295.0 & 28.5 & 0.13 & $\mathrm{~N}$ & 1 & 1 \\
\hline $4, \mathrm{CC}$ & 113.00 & 251.4 & 20.6 & 0.05 & & & & & $?$ & & \\
\hline $5-1,103-105$ & 114.04 & 294.9 & 61.3 & 0.07 & 150 & 251.3 & 26.7 & 0.10 & $\mathrm{~N}$ & 1 & 3 \\
\hline $5-2,54-56$ & 115.05 & 97.5 & 0.7 & 0.14 & 50 & 86.5 & -11.0 & 0.11 & $\mathrm{R}$ & 2 & 3 \\
\hline $5-3,103-105$ & 117.04 & 77.5 & -30.2 & 0.09 & 150 & 90.8 & -29.5 & 0.07 & $\mathrm{R}$ ? & 3 & 3 \\
\hline $5-4,51-53$ & 118.02 & 268.0 & 21.8 & 0.08 & 50 & 270.8 & 10.9 & 0.06 & $\mathrm{~N}$ ? & 3 & 2 \\
\hline $5, \mathrm{CC}$ & 122.50 & 275.1 & 24.1 & 0.17 & 50 & 266.4 & 26.0 & 0.14 & $\mathrm{~N}$ & 3 & 2 \\
\hline $6-1,102-104$ & 123.53 & 305.9 & 29.0 & 0.02 & & & & & $?$ & & · \\
\hline $6-2,87-89$ & 124.88 & 350.1 & 45.7 & 0.07 & 150 & 292.0 & 11.7 & 0.07 & $\mathrm{~N} ?$ & 3 & 3 \\
\hline $6-3,84-86$ & 126.35 & 9.1 & 45.0 & 0.08 & 50 & 3.5 & 65.8 & 0.06 & $\mathrm{~N}$ & 2 & 3 \\
\hline $6-4,79-81$ & 127.80 & 290.0 & 30.1 & 0.05 & & & & & $?$ & & \\
\hline $6, \mathrm{CC}$ & 132.00 & 43 & -58.1 & 0.02 & & & & & $?$ & & \\
\hline $7-1,128-130$ & 133.29 & 126.5 & 9.2 & 0.06 & & & & & $?$ & & \\
\hline $7-2,74-76$ & 134.25 & 238.8 & 37.9 & 0.03 & & & & & $?$ & & \\
\hline $7-3,55-57$ & 135.56 & 256.7 & 38.4 & 0.07 & 150 & 187.8 & -15.5 & 0.05 & $\mathrm{R}$ ? & 3 & 4 \\
\hline $7-4,36-38$ & 136.87 & 150.5 & 24.7 & 0.04 & & & & & $?$ & & \\
\hline $7-5,100-102$ & 139.01 & 301.6 & 77.2 & 0.05 & & & & & $?$ & & \\
\hline $7-6,95-97$ & 140.46 & 135.1 & 53.3 & 0.05 & 50 & 252.3 & -68.1 & 0.43 & $\mathrm{R}$ ? & 3 & 4 \\
\hline $8-1,55-57$ & 142.06 & 193.7 & -56.3 & 0.01 & & & & & $?$ & & \\
\hline $8-2,98-100$ & 143.99 & 98.8 & 23.8 & 0.06 & 50 & 22.1 & 1.9 & 0.01 & $?$ & 4 & 4 \\
\hline $8-3,8-10$ & 144.59 & 315.3 & 1.4 & 0.03 & 50 & 198.2 & -24.4 & 0.02 & $?$ & & \\
\hline $8-4,123-125$ & 147.22 & 188.6 & 19.2 & 0.06 & 50 & 132.0 & 63.0 & 0.04 & $?$ & & \\
\hline $8-5,123-125$ & 148.74 & 192.7 & -5.8 & 0.04 & 50 & 200.2 & -19.0 & 0.03 & $\mathrm{R}$ ? & 3 & 3 \\
\hline $8-6,148-150$ & 150.49 & 294.4 & 36.2 & 0.02 & & & & & $?$ & & \\
\hline $8-7,77-79$ & 151.28 & 167.9 & 14.8 & 0.04 & & & & & $?$ & & \\
\hline $9-1,127-129$ & 152.28 & 236.5 & 70.9 & 0.04 & & & & & $?$ & & \\
\hline $9-2,69-71$ & 153.20 & 278.8 & -6.9 & 0.08 & 50 & 1.0 & -7.2 & 0.03 & $\mathrm{R}$ ? & 3 & 3 \\
\hline $9-3,64-66$ & 154.65 & 343.3 & 30.9 & 0.04 & & & & & $?$ & & \\
\hline $9-4,37-39$ & 155.88 & 126.2 & -6.8 & 0.04 & & & & & $?$ & & \\
\hline $9-5,80-82$ & 157.81 & 154.5 & 11.0 & 0.02 & & & & & $?$ & & \\
\hline $9-6,99-101$ & 159.50 & 134.9 & -8.8 & 0.04 & & & & & $?$ & & \\
\hline $10-1,88-90$ & 161.39 & 197.8 & -39.6 & 0.03 & & & & & $?$ & & \\
\hline $10-2,75-77$ & 162.76 & 96.1 & -73.0 & 0.02 & & & & & $?$ & & \\
\hline $10-3,60-62$ & 164.16 & 292.3 & -2.2 & 0.02 & & & & & $?$ & & \\
\hline $10-4,68-70$ & 165.69 & 254.2 & 62.3 & 0.12 & 50 & 207.1 & -60.1 & 0.04 & $\mathrm{R}$ ? & 3 & 3 \\
\hline $10-5,51-53$ & 167.02 & 172.3 & 25.3 & 0.08 & 50 & 113.1 & -32.5 & 0.04 & $\mathrm{R}$ ? & 3 & 3 \\
\hline $10-6,38-40$ & 168.39 & 189.1 & -6.9 & 0.04 & & & & & $?$ & & \\
\hline $10-7,26-28$ & 169.77 & 174.8 & -2.1 & 0.04 & & & & & $?$ & & \\
\hline $11-1,32-34$ & 170.33 & 100.3 & 22.4 & 0.08 & & 82.9 & 39.1 & 0.06 & $?$ & 2 & 3 \\
\hline $11-2,21-23$ & 171.72 & 210.2 & 45.4 & 0.34 & 150 & 197.3 & 59.8 & 0.13 & $\mathrm{~N}$ & 2 & 1 \\
\hline $11-3,25-27$ & 173.26 & 254.1 & 68.9 & 0.19 & 300 & 326.9 & -1.5 & 0.09 & $\mathrm{R}$ ? & 3 & 2 \\
\hline $11-4,19-21$ & 174.70 & 149.0 & 3.2 & 2.37 & 300 & 144.1 & -28.5 & 2.32 & $\mathrm{R}$ & 1 & 1 \\
\hline $11-5,39-41$ & 176.40 & 100.9 & 13.4 & 6.97 & 300 & 254.3 & -29.2 & 2.72 & $\mathrm{R}$ & 1 & 1 \\
\hline $12-1,96-98$ & 180.47 & 194.9 & 37.5 & 8.53 & 300 & 107.7 & -33.6 & 0.54 & $\mathrm{R}$ & 1 & 3 \\
\hline $12-2,26-28$ & 181.27 & 152.3 & 65.4 & 5.91 & 300 & 153.9 & 52.8 & 0.98 & $\mathrm{~N}$ & 1 & 2 \\
\hline $12-3,43-45$ & 182.94 & 18.0 & 46.9 & 10.96 & 300 & 356.0 & 38.9 & 2.57 & $\mathrm{~N}$ ? & 1 & 1 \\
\hline $12-4,110-112$ & 185.11 & 39.2 & 24.8 & 6.35 & 300 & 78.7 & -25.9 & 2.27 & $\mathrm{R}$ & 1 & 1 \\
\hline $12-5,37-39$ & 185.88 & 182.7 & 18.8 & 4.22 & 300 & 215.4 & -45.3 & 2.03 & $\mathrm{R}$ & 1 & 1 \\
\hline $13-1,51-53$ & 189.52 & 257.0 & 58.2 & 13.61 & 300 & 255.0 & 27.3 & 3.37 & N? & 1 & 1 \\
\hline $13-2,33-35$ & 190.84 & 30.8 & 47.2 & 8.30 & 300 & 120.6 & 54.4 & 0.47 & $?$ & 4 & 4 \\
\hline $13-3,47-49$ & 192.48 & 218.2 & 48.0 & 8.43 & 300 & 44.5 & -74.7 & 1.36 & $\mathrm{R}$ & 1 & 3 \\
\hline $13-4,8-10$ & 193.59 & 254.9 & 44.8 & 8.13 & 300 & 257.7 & -32.2 & 0.91 & $\mathrm{R}$ & 1 & 3 \\
\hline $13-5,121-123$ & 196.22 & 90.8 & 3.0 & 16.81 & 300 & 99.4 & -22.5 & 11.76 & $\mathrm{R}$ & 1 & 1 \\
\hline $14-1,109-111$ & 199.60 & 346.7 & -18.8 & 0.11 & 300 & 310.1 & 48.7 & 0.22 & $\mathrm{~N}$ & 1 & 2 \\
\hline $14-2,27-29$ & 200.28 & 111.6 & 49.8 & 0.68 & 300 & 60.2 & 41.8 & 0.73 & $\mathrm{~N}$ & 1 & 1 \\
\hline $14-3,64-66$ & 202.15 & 225.6 & 68.3 & 0.25 & 300 & 76.4 & 49.9 & 0.13 & N? & 2 & 4 \\
\hline $14-4,57-59$ & 203.58 & 189.5 & 74.6 & 13.19 & 300 & 324.0 & -43.7 & 3.04 & $\mathrm{R}$ & 1 & 1 \\
\hline $14-5,40-42$ & 204.91 & 180.0 & 48.3 & 6.38 & 300 & 266.0 & -52.8 & 2.05 & $\mathrm{R}$ & 1 & 1 \\
\hline
\end{tabular}


TABLE 2 - Con tinued

\begin{tabular}{|c|c|c|c|c|c|c|c|c|c|c|c|}
\hline \multirow{2}{*}{$\begin{array}{c}\text { Sample } \\
\text { (Interval in cm) }\end{array}$} & \multirow[b]{2}{*}{ Depth } & \multicolumn{3}{|c|}{ NRM } & \multirow{2}{*}{$\begin{array}{l}\text { Demag. } \\
\text { Field }\end{array}$} & \multicolumn{3}{|c|}{ After Demagnetization } & \multirow[b]{2}{*}{ Polarity } & \multicolumn{2}{|c|}{ Category $^{\mathrm{a}}$} \\
\hline & & Dec. & Inc. & Int. & & Dec. & Inc. & Int. & & Polarity & Direction \\
\hline $16-1,127-129$ & 218.78 & 70.1 & 72.2 & 0.57 & 300 & 346.1 & -35.2 & 0.62 & $\mathrm{R}$ & 1 & 1 \\
\hline $16-2,21-23$ & 219.22 & 188.9 & 40.2 & 2.01 & 300 & 51.6 & -21.7 & 0.50 & $\mathrm{R}$ & 1 & 2 \\
\hline $16-3,18-20$ & 220.69 & 179.2 & 46.6 & 3.13 & 300 & 134.5 & -59.8 & 0.94 & $\mathrm{R}$ & 1 & 1 \\
\hline $17-1,66-68$ & 227.67 & 193.1 & 61.4 & 1.39 & 300 & 336.7 & -47.2 & 1.05 & $\mathrm{R}$ & 1 & 2 \\
\hline $17-2,127-129$ & 229.78 & 240.4 & 47.3 & 6.67 & 300 & 315.0 & -64.9 & 0.57 & $\mathbf{R}$ & 1 & 3 \\
\hline $17-3,4-6$ & 230.05 & 196.0 & 49.1 & 3.29 & 300 & 284.3 & -59.8 & 0.46 & $\mathrm{R}$ & 1 & 3 \\
\hline $18-1,9-11$ & 236.60 & 41.9 & 708 & 3.37 & 300 & 72.7 & 30.2 & 0.73 & $\mathrm{~N}$ & 1 & 2 \\
\hline $18-1,30-32$ & 236.81 & 26.6 & 03.8 & 4.43 & 450 & 94.0 & -21.2 & 0.12 & $\mathrm{R}$ ? & 3 & 3 \\
\hline $18-2,11-13$ & 238.12 & 34.1 & -60.8 & 7.13 & 300 & 4.6 & -72.8 & 0.57 & $\mathrm{R}$ & 1 & 3 \\
\hline $18-2,43-45$ & 238.44 & 333.3 & -26.5 & 14.59 & 300 & 315.7 & -17.2 & 0.59 & $\mathrm{R}$ & 1 & 2 \\
\hline $19-1,72-74$ & 246.73 & 266.3 & 54.0 & 20.71 & 300 & 243.0 & 56.5 & 1.67 & $\mathrm{~N}$ & 1 & 1 \\
\hline
\end{tabular}

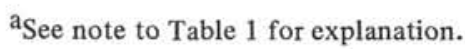

oe, and in many cases the stability of the magnetization is questionable and the reliability of the polarity determinations is uncertain. Paleomagnetic studies of the underlying Cretaceous sediment were, however, more fruitful.

The Cretaceous sequence encountered in Cores 5 to 35 (Figure 11) comprises a series of hard, indurated, dark-colored siliceous limestones and calcareous claystones of late Albian age in Cores 5 to 11 (approximately 175 to 232 m sub-bottom), underlain by a series of softer, less indurated, carbonaceous mudstones ("black shales") of early Aptian to middle Albian age in Cores 11 to 35 (approximately 232 to $480 \mathrm{~m}$ sub-bottom). Core recovery within the upper hard indurated sediments was generally poor, and restricted to fragments varying in length from a few $\mathrm{cm}$ to about $20 \mathrm{~cm}$. Few of these fragments were sufficiently long to eliminate the possibility of significant rotation about horizontal axes, and thus allow a reliable evaluation of uphole direction to be made. Suitable material for paleomagnetic sampling was available only from Cores 5, 6, and 9, and the results of measurements on these samples are shown in Figure 12.

The majority of samples from Cores 5 to 9 were incrementally demagnetized in three or four stages to a maximum field of $100 \mathrm{Oe}$, above which point their remanence became too weak for reliable measurement. On the basis of this treatment at least two reversed zones appear to be present, one in the uppermost sample taken from Core 5, and the other defined by four samples from the uppermost core fragment at the top of Core 6 . These are separated by a normally magnetized zone defined by two samples with positive inclinations. A single sample (402A-6-1, 12-14) within the reversely magnetized zone of Core 6 appears to have a normal polarity (Table 3 ), so that a total of three reverse zones, separated by two normal zones, are present within the depth range 176 to 185 meters. Since the total length of core actually sampled in this interval is only 0.5 meters, it is quite possible that a number of other polarity reversal boundaries exist within the unsampled part of this range.

Two samples per core section were taken from the lower sequence of less-indurated carbonaceous mudstones ("black shales') drilled at this site. Incremental demagnetization to 500 Oe was carried out for seven samples, and the results suggested that a single treatment at 100 Oe was sufficient to reliably establish the polarity of stable remanence.
Consequently, with the exception of a few anomalous samples which were investigated in more detail, the remaining 123 samples from this site were demagnetized at a single field of $100 \mathrm{Oe}$. With the exception of a thin reversed zone at the top of Core 33 and one of undefined thickness at the top of Core 30 , a normal magnetic polarity was established for the whole section, in accord with deposition during the long Cretaceous interval of constant normal polarity.

The reversed zones in Cores 30 and 33 are each defined on the basis of four closely spaced samples, and have mean inclinations values of $-\left(52 \pm 11^{\circ}\right)$ and $-\left(53 \pm 7^{\circ}\right)$, respectively, compared with an overall mean inclination for the normally magnetized samples of $+\left(51 \pm 15^{\circ}\right)$. It is concluded that these reversed zones represent real magnetic events, of short duration, within the Parhabdolithus angustus Zone of the upper Aptian (Figure 12). These events may have value as stratigraphic markers within the long Cretaceous interval of normal polarity. The maximum duration of the lower reverse event, based on the position of the nearest samples with normal polarity above and below the reverse interval is approximately 50,000 years. Because paleomagnetic samples were taken at an average spacing of $75 \mathrm{~cm}$ throughout the Cretaceous section, and several gaps exist due to poor core recovery, it is possible that other short events of similar duration have been missed.

No direct evidence was found at either Hole $400 \mathrm{~A}$ or $402 \mathrm{~A}$ for a prolonged interval of reversed polarity at the Aptian/Albian boundary, that might correspond with the "Gatan"' Zone of Pechersky and Khramov (1973) and Van Hinte (1976). Accepting that this zone (equivalent to marine magnetic anomaly " $M O$ ") is located within the interval of predominantly normal polarity extending from early Barremian to late Santonian time, the paleomagnetic results from Holes $400 \mathrm{~A}$ and $402 \mathrm{~A}$ suggest two possible explanations. Firstly, the "Gatan"' Zone may lie within the 40 -meter gap in the polarity record at Hole $402 \mathrm{~A}$ between Cores 26 and 29 (Figure 12). This suggestion is supported by the fact that the uppermost samples in the section beneath this gap correspond with one of the short reversed polarity events discussed above. The alternative possibility is that the "'Gatan Zone"' (and hence anomaly $M O$ ) corresponds with the upper Albian interval of mixed polarity identified at both sites, and also at DSDP Site 263 (Green and Brecher, 1974; 


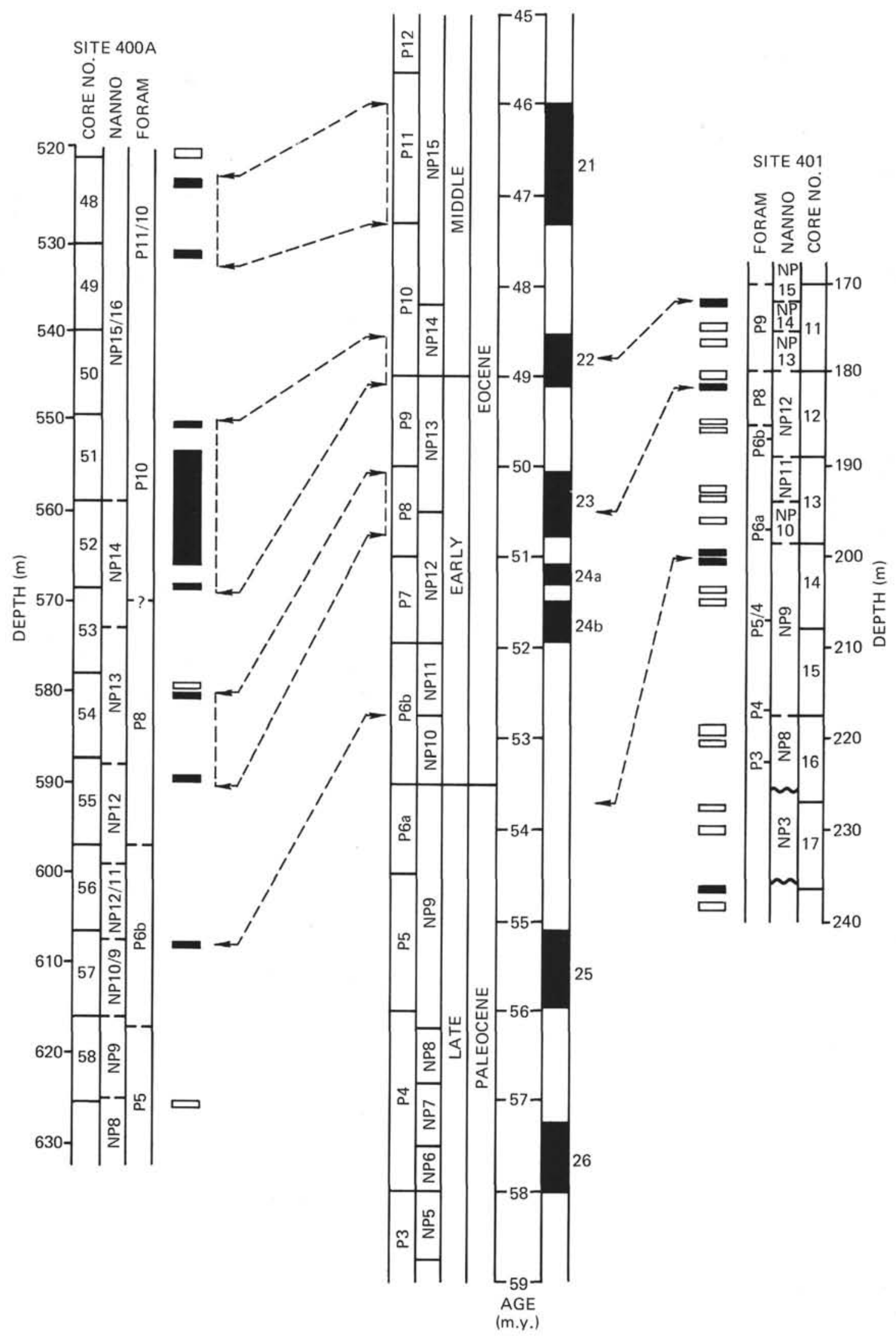

Figure 8. Magnetic polarity determinations for Hole $400 \mathrm{~A}$ and Site 401, and comparison with revised Paleogene polarity timescale of Hailwood et al. (this volume). Normal polarity shaded, reverse white. 

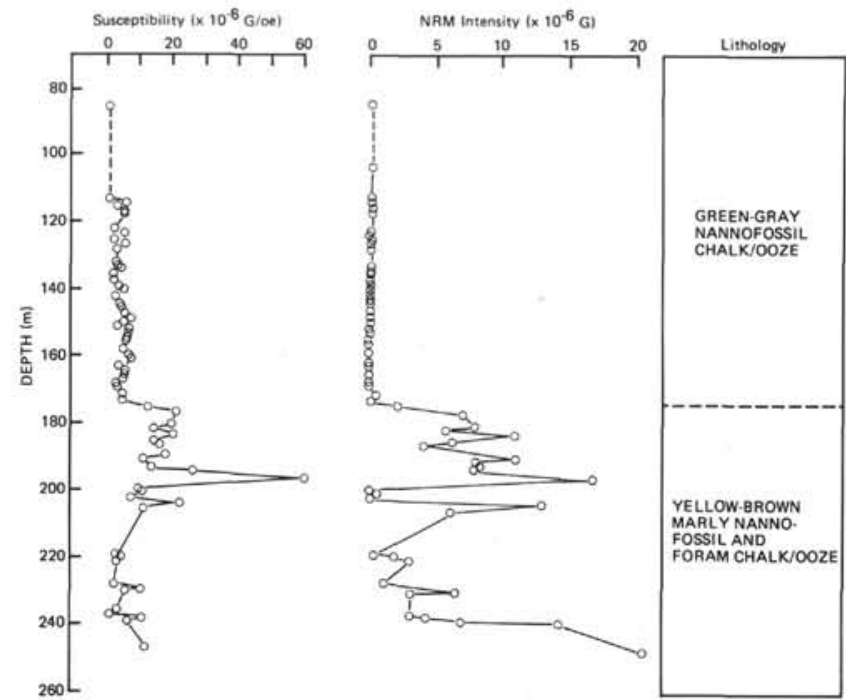

Figure 9. Site 401, correlation between magnetic susceptibility, NRM intensity, and lithology.
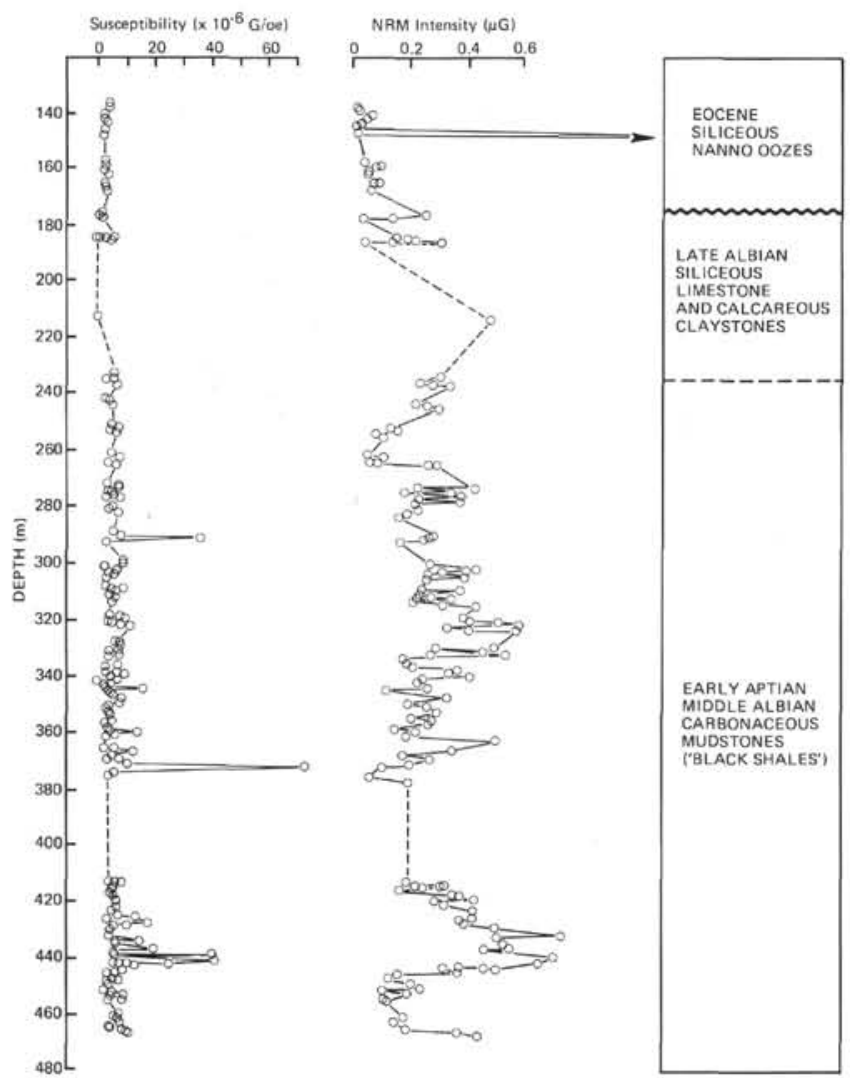

Figure 10. Downhole plot of magnetic susceptibility and NRM intensity values for Hole $402 \mathrm{~A}$.

Jarrard, 1974) and that no separate reverse polarity event exists at the Aptian/Albian boundary. Since the implied late Albian age for anomaly $M O$ is not consistent with the position of this anomaly in the marine magnetic profiles for the Hawaiian area of Larson and Hilde (1975), the former explanation is preferred here.
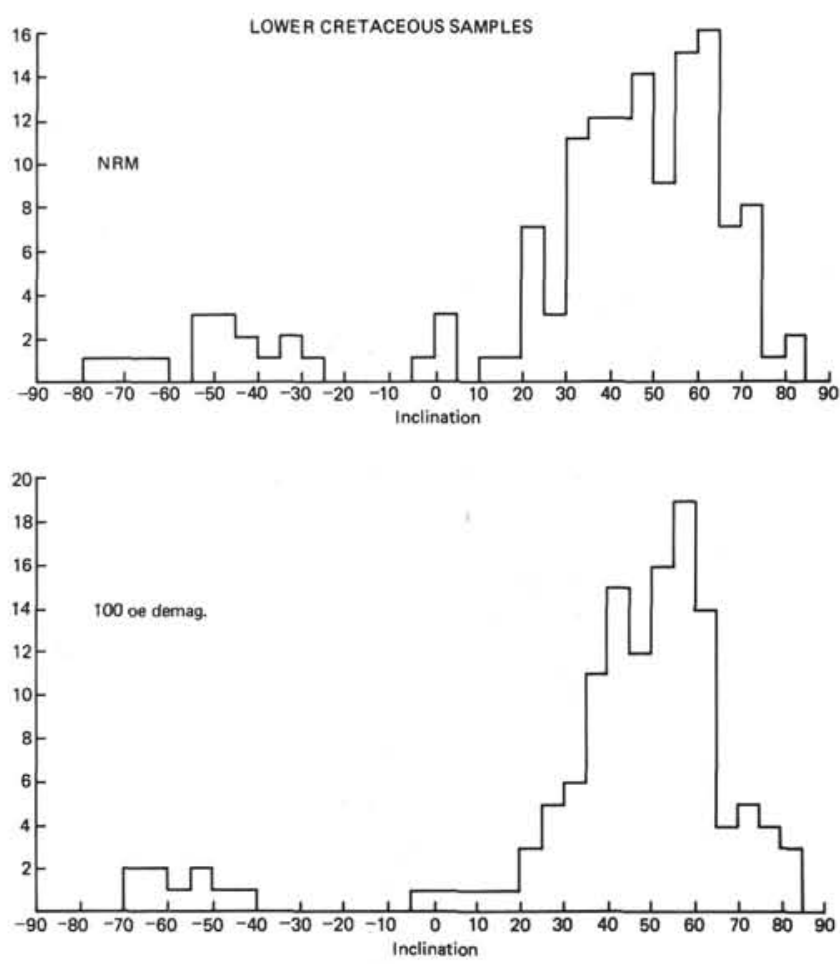

Figure 11. Histograms of inclination values for early Cretaceous "black shales" at Hole 402A.

\section{Magnetic Susceptibility and NRM Intensity}

Downhole plots of magnetic susceptibility and NRM intensity values for Hole 402A are presented in Figure 10. There is a clear distinction between the mean NRM intensity and susceptibility values for the weakly magnetic Eocene siliceous nannofossil oozes of Cores 1 to 4 and the significantly higher values for the underlying carbonaceous mudstones. Within these carbonaceous mudstones the NRM intensity values appear to show a series of quasicyclical fluctuations with a wavelength of about 60 meters. The absence of similar fluctuations in the susceptibility record suggests that their origin might lie in secular variation of the geomagnetic field intensity rather than fluctuations in supply of magnetic material. The periodicity of this secular variation would be about 1.2 million years.

\section{Cretaceous Paleolatitudes}

Figure 11 shows a histogram of the inclination values for the 150 Early Cretaceous samples from Hole 402A before and after treatment at $100 \mathrm{Oe}$. The NRM inclinations show a broad distribution of values, presumably reflecting the presence of secondary components of variable magnitude. However AF demagnetization at 100 Oe considerably reduces the spread of values, and results in a clear bimodal distribution centered on mean values of about $\pm 55^{\circ}$. Since only relative magnetic declination values are determinable in these cores, it is not possible to calculate a mean paleomagnetic pole position. However, it is possible to test whether or not the mean inclination of stable magnetic remanence is consistent with other data for the Western European plate by using this value to calculate the paleomagnetic colatitude. This colatitude value can then be 


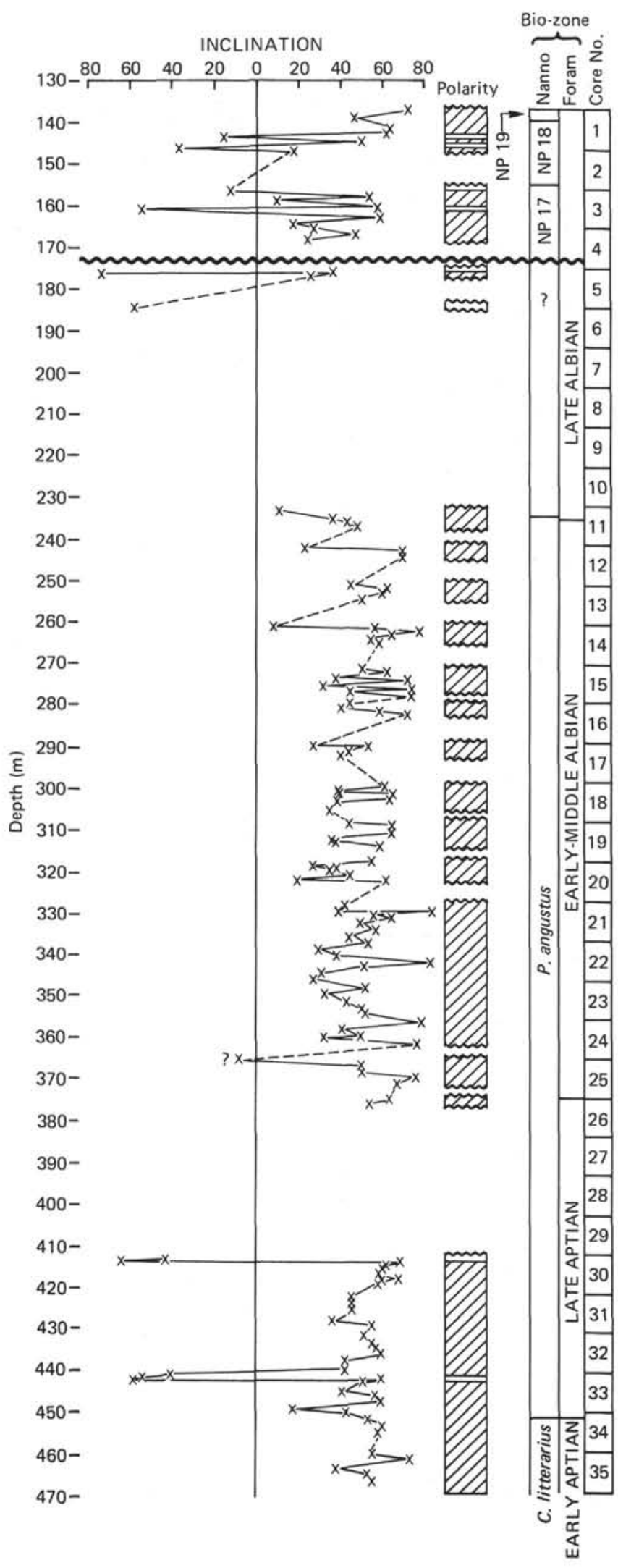

Figure 12. Plot of downhole variation in magnetic inclination, and inferred polarity reversal sequence for Hole $402 \mathrm{~A}$. used for constructing a curve representing the locus of possible Apparent Geomagnetic Pole (A.G.P.) positions with respect to the sampling site.

The pole-position locus for Hole $402 \mathrm{~A}$ is plotted in Figure 13, together with the post-upper Carboniferous polar wander curve for Western Europe, derived by Van der Voo and French (1974) from a synthesis of marine magnetic anomaly data and paleomagnetic determinations from the circum-Atlantic continents. The 402A Early Cretaceous A.G.P. locus passes exactly through the Early Cretaceous pole position of Van der Voo and French, and it may be concluded that the paleomagnetic inclination determinations for Hole 402A Early Cretaceous sediments are consistent with models for the movement of the European plate, based on marine magnetic anomalies and available continental paleomagnetic data.

\section{Rockall Plateau}

In the first part of this section the magnetic stability characteristics of the sediments recovered at Sites 403 to 405 are discussed, and the reliability of the polarity determinations is evaluated. In the final part a synthesis of the polarity stratigraphy at the three sites is presented, and some preliminary interpretations are made, in terms of the dating of marine anomalies, and the timing of tectonic events in the northeast Atlantic.

\section{Sites $\mathbf{4 0 3}$ and $\mathbf{4 0 4}$}

Sites 403 and 404 are located towards the southern end of the rifted westerly margin of the Rockall-Hatton Plateau, in water depths of 2300 meters, about $30 \mathrm{~km}$ east of the oldest magnetic anomaly (24) recorded in the adjacent oceanic lithosphere. At Site 403 some 230 meters of foraminifer nannofossil oozes and chalks ranging in age from Holocene to Oligocene, unconformably overlie a thick Paleocene-Eocene section of deltaic aspect. The latter sequence is composed dominantly of volcanogenic siltstones and glauconitic mudstones; paleomagnetic studies for Site 403 have been restricted to this section (Cores 26 to 46).

\section{Paleomagnetic Results From Site 403}

1) Stability tests: All samples were subjected to AF demagnetization at one or more fields in the range 100 to 300 $\mathrm{Oe}$, and occasionally up to $750 \mathrm{Oe}$, on the ship. They were then demagnetized a second time in the shore laboratory, at fields in the range 100 to $800 \mathrm{Oe}$, to investigate the stability of secondary components acquired in the intervening period of up to six months. Representative examples of the response of samples to this treatment are shown in Figure 14. Samples $34-3,45-47 \mathrm{~cm}$ and $34-3,118-120 \mathrm{~cm}$ (Table 4) showed well-defined directions of magnetization with negative inclinations after treatment at 100 and 300 Oe on the ship, but by the time they were remeasured in the shore laboratory, they had acquired a strong secondary component, such that their intensities of magnetization were nearly double the shipboard NRM value. That this secondary magnetization is a relatively unstable viscous remanent magnetism (VRM), probably acquired as a result of storage in the earth's field, rather than a stable chemical remanent magnetism (CRM), resulting from drying out, is suggested by the fact that the 
TABLE 3

Hole 402A: Paleomagnetic Results

\begin{tabular}{|c|c|c|c|c|c|c|c|c|c|c|c|}
\hline \multirow{2}{*}{$\begin{array}{c}\text { Sample } \\
\text { (Interval in } \mathrm{cm} \text { ) }\end{array}$} & \multirow[b]{2}{*}{ Depth } & \multicolumn{3}{|c|}{ NRM } & \multirow{2}{*}{$\begin{array}{l}\text { Demag. } \\
\text { Field }\end{array}$} & \multicolumn{3}{|c|}{ After Demagnetization } & \multirow[b]{2}{*}{ Polarity } & \multicolumn{2}{|c|}{ Category $^{\mathrm{a}}$} \\
\hline & & Dec. & Inc. & Int. & & Dec. & Inc. & Int. & & Polarity & Direction \\
\hline $1-1,19-21$ & 137.20 & 291.8 & 63.7 & 0.02 & 50 & 350.4 & 71.3 & 0.05 & $\mathrm{~N}$ & 2 & 4 \\
\hline $1-2,63-65$ & 139.14 & 283.5 & 46.1 & 0.03 & 50 & 22.8 & 46.0 & 0.06 & $\mathrm{~N}$ & 2 & 4 \\
\hline $1-3,88-90$ & 140.89 & 206.1 & 67.5 & 0.06 & 25 & 347.0 & 63.4 & 0.03 & $\mathrm{~N}$ & 2 & 4 \\
\hline $1-4,81-83$ & 142.32 & 344.8 & 63.8 & 0.05 & 25 & 123.3 & 62.9 & 0.04 & $\mathrm{~N}$ & 3 & 4 \\
\hline $1-5,54-56$ & 143.55 & 333.4 & -38.2 & 0.03 & 25 & 212.1 & -15.0 & 0.02 & $\mathbf{R}$ & 3 & 4 \\
\hline $1-6,24-26$ & 144.75 & 281.4 & 24.0 & 0.02 & 25 & 260.2 & 50.4 & 0.04 & $\mathrm{~N}$ & 4 & 4 \\
\hline $1-6,128-130$ & 145.79 & 191.9 & 68.7 & 0.03 & 25 & 283.2 & -32.0 & 0.03 & $\mathrm{R}$ & 4 & 4 \\
\hline $1-7, \mathrm{CC}$ & 146.50 & 175.9 & -14.6 & 18.36 & 25 & 140.4 & 17.3 & 12.04 & $\mathrm{~N}$ & 1 & 2 \\
\hline $2-1,51-53$ & 147.02 & 54.9 & 52.0 & 0.02 & 50 & 79.6 & -34.8 & 0.03 & $\mathrm{R}$ & 3 & 4 \\
\hline $3-1,70-72$ & 156.71 & 255.5 & 61.7 & 0.04 & 25 & 251.1 & -11.6 & 0.02 & $\mathrm{R}$ & 3 & 4 \\
\hline $3-2,45-47$ & 157.96 & 333.5 & 28.2 & 0.10 & 100 & 316.1 & 53.6 & 0.05 & $\mathrm{~N}$ & 2 & 3 \\
\hline $3-2,83-85$ & 158.34 & 164.7 & -16.8 & 0.08 & 25 & 131.1 & 10.9 & 0.04 & $\mathrm{~N}$ & 3 & 4 \\
\hline $3-3,87-89$ & 159.88 & 254.7 & 71.0 & 0.06 & 25 & 249.1 & 57.0 & 0.08 & $\mathrm{~N}$ & 2 & 3 \\
\hline $3-4,49-51$ & 161.00 & 108.9 & 53.8 & 0.06 & 25 & 335.2 & -53.6 & 0.02 & $\mathbf{R}$ & 3 & 4 \\
\hline $3-5,55-57$ & 162.56 & 352.4 & 15.5 & 0.06 & 25 & 297.3 & 59.9 & 0.04 & $\mathrm{~N}$ & 3 & 4 \\
\hline $3-6,42-44$ & 163.93 & 20.0 & 4.1 & 0.09 & 25 & 32.4 & 18.0 & 0.05 & $\mathrm{~N}$ & 3 & 4 \\
\hline $3-7,23-25$ & 165.24 & 23.3 & 72.9 & 0.08 & 50 & 55.2 & 26.7 & 0.04 & $\mathrm{~N}$ & 3 & 4 \\
\hline $4-1,142-144$ & 166.93 & 300.6 & 13.5 & 0.07 & 50 & 188.3 & 46.9 & 0.06 & $\mathrm{~N}$ & 3 & 4 \\
\hline $4-2,75-77 ?$ & 167.86 & 61.6 & 43.8 & 0.07 & 50 & 89.4 & 25.1 & 0.05 & $\mathrm{~N}$ & 3 & 3 \\
\hline $5-1,114-116$ & 176.15 & 255.1 & -38.3 & 0.26 & 50 & 51.5 & -73.4 & 0.05 & $\mathrm{R}$ & 2 & 4 \\
\hline $5-1,143-145$ & 176.44 & 297.6 & -34.4 & 0.04 & 50 & 320.7 & 36.2 & 0.12 & $\mathrm{~N}$ & 2 & 3 \\
\hline $5-2,3-5$ & 176.54 & 260.2 & 3.6 & 0.14 & 50 & 295.9 & 26.0 & 0.06 & $\mathrm{~N}$ & 3 & 4 \\
\hline $6-1,2-4$ & 184.53 & 152.5 & -71.5 & 0.16 & 100 & 68.0 & -45.7 & 0.15 & $\mathbf{R}$ & 2 & 3 \\
\hline $6-1,6-8$ & 184.57 & 260.8 & -75.6 & 0.20 & 100 & 276.8 & -67.0 & 0.17 & $\mathbf{R}$ & 1 & 2 \\
\hline $6-1,8-10$ & 184.59 & 17.3 & -26.9 & 0.23 & 100 & 33.4 & -62.9 & 0.19 & $\mathbf{R}$ & 2 & 3 \\
\hline $6-1,12-14$ & 184.63 & 92.8 & -2.3 & 0.32 & 100 & 128.2 & 30.1 & 0.42 & $\mathrm{~N}$ & 2 & 3 \\
\hline $6-1,14-16$ & 184.65 & 156.0 & -32.7 & 0.14 & 100 & 311.2 & -55.6 & 0.09 & $\mathbf{R}$ & 2 & 4 \\
\hline $6-1,33-35$ & 184.85 & 296.8 & 34.9 & 0.05 & 100 & 300.5 & -33.6 & 0.04 & $?$ & 3 & 4 \\
\hline $9-1,3-5$ & 213.04 & 280.2 & -66.0 & 0.49 & 50 & 274.4 & -3.9 & 0.10 & $\mathrm{R}$ & 3 & 4 \\
\hline $11-1,92-94$ & 232.09 & 6.3 & 35.6 & 0.31 & 100 & 11.1 & 10.9 & 0.11 & $\mathrm{~N}$ & 2 & 3 \\
\hline $11-2,144-146$ & 234.95 & 90.2 & 23.5 & 0.25 & 100 & 89.8 & 37.1 & 0.12 & $\mathrm{~N}$ & 2 & 3 \\
\hline $11-3,79-81$ & 235.80 & 316.7 & 28.7 & 0.29 & 100 & 276.8 & 43.4 & 0.16 & $\mathrm{~N}$ & 1 & 2 \\
\hline $11-4,22-24$ & 236.73 & 343.2 & 30.9 & 0.35 & 100 & 319.0 & 48.2 & 0.27 & $\mathrm{~N}$ & 1 & 2 \\
\hline $12-1,79-81$ & 242.30 & 348.5 & 28.1 & 0.23 & 300 & 317.5 & 40.4 & 0.15 & $\mathrm{~N}$ & 2 & 3 \\
\hline $12-1,12-14$ & 243.13 & 320.9 & 47.6 & 0.27 & 300 & 308.2 & 49.2 & 0.17 & $\mathrm{~N}$ & 2 & 3 \\
\hline $12-1,82-84$ & 243.83 & 353.7 & 33.6 & 0.31 & 100 & 333.3 & 69.7 & 0.18 & $\mathrm{~N}$ & 2 & 3 \\
\hline $13-1,23-25$ & 251.24 & 191.3 & 49.2 & 0.15 & 100 & 213.6 & 45.4 & 0.06 & $\mathrm{~N}$ & 2 & 3 \\
\hline $13-1,90-92$ & 251.91 & 208.4 & 71.0 & 0.17 & 100 & 236.3 & 63.4 & 0.11 & $\mathrm{~N}$ & 2 & 3 \\
\hline $13-2,45-47$ & 252.96 & 82.2 & 55.2 & 0.09 & 100 & 122.0 & 60.0 & 0.10 & $\mathrm{~N}$ & 2 & 3 \\
\hline $13-2,134-136$ & 253.85 & 238.1 & 64.1 & 0.12 & 100 & 239.4 & 49.5 & 0.08 & $\mathrm{~N}$ & 2 & 3 \\
\hline $14-1,46-48$ & 260.97 & 228.2 & 55.5 & 0.07 & 100 & 240.9 & 7.3 & 0.05 & $\mathrm{~N}$ & 3 & 3 \\
\hline $14-1,118-120$ & 261.69 & 247.0 & 61.5 & 0.12 & 100 & 249.5 & 56.5 & 0.12 & $\mathrm{~N}$ & 2 & 3 \\
\hline $14-2,40-42$ & 262.41 & 242.3 & 80.5 & 0.08 & 100 & 177.9 & 78.5 & 0.08 & $\mathrm{~N}$ & 2 & 3 \\
\hline $14-2,124-126$ & 263.25 & 179.0 & 61.8 & 0.10 & 100 & 172.8 & 64.6 & 0.21 & $\mathrm{~N}$ & 2 & 2 \\
\hline $14-3,62-64$ & 264.13 & 343.6 & 60.7 & 0.28 & 100 & 300.9 & 55.2 & 0.18 & $\mathrm{~N}$ & 2 & 3 \\
\hline $14-3,106-108$ & 264.57 & 49.8 & 62.5 & 0.31 & 100 & 105.0 & 58.5 & 0.18 & $\mathrm{~N}$ & 2 & 3 \\
\hline $15-2,19-21$ & 271.70 & 3.9 & 32.5 & 0.44 & 100 & 19.8 & 51.2 & 0.32 & $\mathrm{~N}$ & 2 & 3 \\
\hline $15-2,121-123$ & 272.72 & 56.5 & 57.5 & 0.24 & 100 & 98.5 & 62.7 & 0.21 & $\mathrm{~N}$ & 2 & 3 \\
\hline $15-3,41-43$ & 273.42 & 324.2 & 41.1 & 0.35 & 100 & 299.2 & 38.1 & 0.19 & $\mathrm{~N}$ & 2 & 3 \\
\hline $15-3,102-104$ & 274.03 & 255.5 & 73.7 & 0.20 & 100 & 212.7 & 71.0 & 0.13 & $\mathrm{~N}$ & 2 & 3 \\
\hline $15-4,52-54$ & 275.03 & 335.9 & 23.2 & 0.43 & 100 & 328.1 & 32.4 & 0.29 & $\mathrm{~N}$ & 2 & 2 \\
\hline $15-4,135-137$ & 275.86 & 80.8 & 71.3 & 0.25 & 100 & 89.6 & 74.0 & 0.19 & $\mathrm{~N}$ & 2 & 2 \\
\hline $15-5,52-54$ & 276.53 & 29.0 & 38.2 & 0.39 & 100 & 24.6 & 45.2 & 0.22 & $\mathrm{~N}$ & 2 & 2 \\
\hline $15-5,124-126$ & 277.25 & 305.0 & 57.7 & 0.24 & 100 & 260.2 & 73.2 & 0.24 & $\mathrm{~N}$ & 2 & 3 \\
\hline $16-1,44-46$ & 279.95 & 344.2 & 31.3 & 0.24 & 100 & 356.5 & 45.9 & 0.28 & $\mathrm{~N}$ & 2 & 3 \\
\hline $16-1,131-133$ & 280.82 & 349.5 & 24.9 & 0.24 & 100 & 339.4 & 41.4 & 0.23 & $\mathrm{~N}$ & 2 & 3 \\
\hline $16-2,19-21$ & 281.20 & 319.1 & 52.6 & 0.21 & 100 & 276.2 & 58.9 & 0.18 & $\mathrm{~N}$ & 2 & 3 \\
\hline $16-2,98-100$ & 281.99 & 41.0 & 72.6 & 0.18 & 100 & 173.6 & 71.7 & 0.19 & $\mathrm{~N}$ & 2 & 3 \\
\hline $17-1,44-46$ & 289.45 & 359.7 & 34.4 & 0.29 & 100 & 13.9 & 27.7 & 0.15 & $\mathrm{~N}$ & 2 & 3 \\
\hline $17-1,117-119$ & 290.18 & 55.5 & 43.1 & 0.27 & 100 & 88.6 & 52.6 & 0.24 & $\mathrm{~N}$ & 2 & 3 \\
\hline $17-2,30-32$ & 290.81 & 321.9 & 40.7 & 0.26 & 100 & 292.7 & 44.2 & 0.13 & $\mathrm{~N}$ & 2 & 3 \\
\hline $17-2,135-137$ & 291.86 & 58.9 & 55.2 & 0.18 & 100 & 104.5 & 41.5 & 0.11 & $\mathrm{~N}$ & 2 & 3 \\
\hline $18-1,114-116$ & 299.65 & 18.2 & 74.7 & 0.19 & 100 & 162.4 & 61.2 & 0.16 & $\mathrm{~N}$ & 2 & 3 \\
\hline $18-2,46-48$ & 300.47 & 306.0 & 44.4 & 0.45 & 100 & 313.7 & 38.9 & 0.21 & $\mathrm{~N}$ & 2 & 2 \\
\hline $18-2,140-142$ & 301.41 & 355.5 & 43.7 & 0.42 & 100 & 3.6 & 40.2 & 0.25 & $\mathrm{~N}$ & 2 & 2 \\
\hline $18-3,18-20$ & 301.69 & 303.0 & 33.4 & 0.33 & 100 & 285.5 & 64.8 & 0.16 & $\mathrm{~N}$ & 2 & 3 \\
\hline $18-3,93-95$ & 302.44 & 313.6 & 63.1 & 0.28 & 100 & 232.5 & 53.3 & 0.18 & $\mathrm{~N}$ & 2 & 3 \\
\hline $18-4,20-22$ & 303.21 & 348.5 & 31.1 & 0.41 & 100 & 341.7 & 39.1 & 0.21 & $\mathrm{~N}$ & 2 & 2 \\
\hline $18-4,67-69$ & 305.18 & 7.2 & 44.4 & 0.27 & 100 & 315.3 & 34.5 & 0.25 & $\mathrm{~N}$ & 2 & 3 \\
\hline
\end{tabular}


TABLE 3 - Continued

\begin{tabular}{|c|c|c|c|c|c|c|c|c|c|c|c|}
\hline \multirow{2}{*}{$\begin{array}{c}\text { Sample } \\
\text { (Interval in cm) }\end{array}$} & \multirow[b]{2}{*}{ Depth } & \multicolumn{3}{|c|}{ NRM } & \multirow{2}{*}{$\begin{array}{l}\text { Demag. } \\
\text { Field }\end{array}$} & \multicolumn{3}{|c|}{ After Demagnetization } & \multirow[b]{2}{*}{ Polarity } & \multicolumn{2}{|c|}{ Category $^{\mathrm{a}}$} \\
\hline & & Dec. & Inc. & Int. & & Dec. & Inc. & Int. & & Polarity & Direction \\
\hline $19-1,30-32$ & 308.31 & 257.5 & 60.2 & 0.26 & 100 & 234.8 & 45.3 & 0.31 & $\mathrm{~N}$ & 2 & 3 \\
\hline $19-1,92-94$ & 308.93 & 284.4 & 61.1 & 0.39 & 100 & 260.3 & 64.5 & 0.26 & $\mathrm{~N}$ & 2 & 3 \\
\hline $19-2,124-126$ & 310.75 & 61.3 & 42.7 & 0.30 & 100 & 77.9 & 64.4 & 0.25 & $\mathrm{~N}$ & 2 & 3 \\
\hline $19-3,14-16$ & 311.15 & 79.5 & 48.7 & 0.25 & 100 & 90.7 & 60.9 & 0.29 & $\mathrm{~N}$ & 2 & 2 \\
\hline $19-3,78-80$ & 311.79 & 343.5 & 32.6 & 0.36 & 100 & 312.1 & 35.9 & 0.17 & $\mathrm{~N}$ & 2 & 3 \\
\hline $19-3,121-123$ & 312.22 & 124.8 & 58.8 & 0.23 & 100 & 143.8 & 21.7 & 0.22 & $\mathrm{~N}$ & 2 & 3 \\
\hline $19-4,52-54$ & 313.03 & 296.5 & 53.6 & 0.34 & 100 & 268.4 & 37.9 & 0.25 & $\mathrm{~N}$ & 2 & 3 \\
\hline $19-4,119-121$ & 313.70 & 279.9 & 41.3 & 0.45 & 100 & 294.0 & 58.9 & 0.17 & $\mathrm{~N}$ & 2 & 2 \\
\hline $20-1,52-54$ & 318.03 & 81.7 & 30.5 & 0.41 & 100 & 103.2 & 54.3 & 0.39 & $\mathrm{~N}$ & 2 & 3 \\
\hline $20-1,128-130$ & 318.79 & 346.2 & 37.1 & 0.43 & 100 & 356.7 & 26.9 & 0.29 & $\mathrm{~N}$ & 2 & 2 \\
\hline $20-2,31-33$ & 319.32 & 9.0 & 36.1 & 0.53 & 100 & 359.3 & 38.6 & 0.25 & $\mathrm{~N}$ & 2 & 2 \\
\hline $20-2,123-125$ & 320.24 & 11.5 & 28.0 & 0.60 & 100 & 329.6 & 35.0 & 0.29 & $\mathrm{~N}$ & 2 & 3 \\
\hline $20-3,28-30$ & 320.79 & 311.6 & 3.0 & 0.35 & 100 & 299.7 & 45.4 & 0.90 & $\mathrm{~N}$ & 2 & 3 \\
\hline $20-3,30-32$ & 321.81 & 345.8 & 13.3 & 0.43 & 100 & 349.1 & 19.3 & 0.20 & $\mathrm{~N}$ & 2 & 2 \\
\hline $20-4,20-22$ & 322.21 & 331.7 & 37.9 & 0.59 & $1 \mathrm{GO}$ & 326.0 & 63.1 & 0.09 & $\mathrm{~N}$ & 2 & 3 \\
\hline $21-1,124-126$ & 328.25 & 84.7 & 56.5 & 0.52 & 100 & 77.6 & 43.4 & 0.27 & $\mathrm{~N}$ & 2 & 2 \\
\hline $21-2,36-38$ & 328.87 & 60.9 & 67.6 & 0.31 & 100 & 42.9 & 40.2 & 0.21 & $\mathrm{~N}$ & 2 & 2 \\
\hline $21-2,117-119$ & 329.68 & 59.9 & 57.0 & 0.48 & 100 & 12.0 & 84.3 & 0.26 & $\mathrm{~N}$ & 2 & 3 \\
\hline $21-3,33-35$ & 330.34 & 236.6 & 63.7 & 0.56 & 100 & 249.3 & 55.9 & 0.42 & $\mathrm{~N}$ & 2 & 2 \\
\hline $21-3,91-93$ & 330.92 & 200.0 & 74.7 & 0.29 & 100 & 116.9 & 64.5 & 0.27 & $\mathrm{~N}$ & 2 & 3 \\
\hline $21-4,91-93$ & 332.42 & 325.2 & 52.6 & 0.20 & 100 & 318.8 & 49.1 & 0.22 & $\mathrm{~N}$ & 2 & 2 \\
\hline $21-5,123-125$ & 334.24 & 76.6 & 66.9 & 0.21 & 100 & 140.2 & 56.3 & 0.12 & $\mathrm{~N}$ & 2 & 3 \\
\hline $21-6,124-126$ & 335.75 & 283.8 & 48.6 & 0.23 & 100 & 302.2 & 44.1 & 0.24 & $\mathrm{~N}$ & 2 & 2 \\
\hline $22-1,14-16$ & 336.65 & 302.2 & 16.4 & 0.39 & 100 & 339.3 & 51.5 & 0.17 & $\mathrm{~N}$ & 2 & 3 \\
\hline $22-1,83-85$ & 337.34 & 328.2 & 3.6 & 0.36 & & & & & N & 3 & 3 \\
\hline $22-2,45-47$ & 338.46 & 299.7 & 45.5 & 0.43 & 100 & 301.0 & 29.0 & 0.34 & $\mathrm{~N}$ & 2 & 3 \\
\hline $22-3,49-51$ & 340.00 & 65.9 & 55.7 & 0.26 & 100 & 41.7 & 39.2 & 0.26 & $\mathrm{~N}$ & 2 & 3 \\
\hline $22-4,53-55$ & 341.54 & 319.0 & 20.5 & 0.25 & 100 & 4.6 & 82.0 & 0.35 & $\mathrm{~N}$ & 2 & 3 \\
\hline $22-5,15-17$ & 342.66 & 115.7 & 59.6 & 0.28 & 100 & 70.5 & 50.4 & 0.21 & $\mathrm{~N}$ & 2 & 3 \\
\hline $22-6,7-9$ & 344.08 & 350.3 & 62.4 & 0.14 & 100 & 303.6 & 31.1 & 0.18 & $\mathrm{~N}$ & 2 & 3 \\
\hline $23-1,24-26$ & 346.25 & 212.7 & 66.3 & 0.35 & 200 & 266.5 & 37.6 & 0.11 & $\mathrm{~N}$ & 2 & 3 \\
\hline $23-2,46-48$ & 347.97 & 132.2 & 78.9 & 0.22 & 200 & 123.2 & 53.1 & 0.11 & $\mathrm{~N}$ & 2 & 3 \\
\hline $23-3,10-12$ & 349.11 & 339.7 & 38.1 & 0.28 & 100 & 353.2 & 31.6 & 0.12 & $\mathrm{~N}$ & 2 & 2 \\
\hline $23-4,46-48$ & 350.97 & 0.8 & 56.7 & 0.31 & 100 & 25.3 & 43.5 & 0.20 & $\mathrm{~N}$ & 2 & 3 \\
\hline $23-5,103-105$ & 353.04 & 126.8 & 46.9 & 0.23 & 100 & 147.8 & 51.1 & 0.19 & $\mathrm{~N}$ & 2 & 3 \\
\hline $23-6,95-97$ & 354.46 & 44.1 & 59.6 & 0.30 & 100 & 60.8 & 52.1 & 0.22 & $\mathrm{~N}$ & 2 & 2 \\
\hline $24-1,85-87$ & 356.36 & 309.5 & 64.3 & 0.28 & 100 & 301.3 & 79.2 & 0.24 & $\mathrm{~N}$ & 2 & 2 \\
\hline $24-2,56-58$ & 357.57 & 295.6 & 68.1 & 0.19 & 100 & 261.4 & 41.1 & 0.15 & $\mathrm{~N}$ & 2 & 3 \\
\hline $24-3,44-46$ & 358.95 & 341.7 & 64.7 & 0.24 & 100 & 347.2 & 49.0 & 0.20 & $\mathrm{~N}$ & 2 & 3 \\
\hline $24-4,15-17$ & 360.16 & 94.9 & 22.5 & 0.21 & 100 & 63.6 & 32.5 & 0.16 & $\mathrm{~N}$ & 2 & 3 \\
\hline $24-5,8-10$ & 361.59 & 336.8 & 45.5 & 0.53 & 100 & 288.9 & 75.3 & 0.30 & $\mathrm{~N}$ & 2 & 3 \\
\hline $25-1,21-23$ & 365.22 & 353.6 & 65.1 & 0.37 & 100 & 315.6 & -8.3 & 0.02 & $\mathrm{R}$ & 3 & 3 \\
\hline $25-2,17-19$ & 366.68 & 113.6 & 43.8 & 0.20 & 100 & 183.0 & 50.3 & 0.09 & $\mathrm{~N}$ & 2 & 3 \\
\hline $25-3,22-24$ & 368.23 & 34.7 & 32.0 & 0.29 & 100 & 14.2 & 50.7 & 0.17 & $\mathrm{~N}$ & 2 & 3 \\
\hline $25-4,35-37$ & 369.86 & 15.1 & 24.6 & 0.22 & 100 & 92.9 & 75.6 & 0.13 & $\mathrm{~N}$ & 2 & 3 \\
\hline $25-5,19-21$ & 371.20 & 252.6 & 82.6 & 0.13 & 300 & 162.3 & 67.4 & 0.05 & N & 2 & 2 \\
\hline $26-1,36-38$ & 374.87 & 270.8 & 10.7 & 0.09 & 100 & 294.8 & 64.3 & 0.12 & $\mathrm{~N}$ & 2 & 3 \\
\hline $26-1,102-104$ & 375.53 & 234.6 & 38.4 & 0.22 & 100 & 250.8 & 55.2 & 0.07 & $\mathrm{~N}$ & 2 & 3 \\
\hline $30-1,76-78$ & 413.27 & 51.7 & -43.0 & 0.21 & 100 & 22.5 & -44.1 & 0.24 & $\mathrm{R}$ & 2 & 3 \\
\hline $30-1,83-85$ & 413.34 & 339.9 & -46.3 & 0.25 & 100 & 56.0 & -54.9 & 0.29 & $\mathbf{R}$ & 2 & 3 \\
\hline $30-1,94-96$ & 413.45 & 72.4 & -62.9 & 0.35 & 100 & 75.3 & -65.5 & 0.15 & $\mathbf{R}$ & 2 & 2 \\
\hline $30-1,118-120$ & 413.69 & 150.3 & -52.2 & 0.34 & 100 & 115.7 & -69.5 & 0.21 & $\mathrm{R}$ & 2 & 3 \\
\hline $30-2,36-38$ & 414.37 & 267.6 & -71.6 & 0.27 & 100 & 261.8 & 68.2 & 0.22 & $\mathrm{~N}$ & 2 & 2 \\
\hline $30-2,119-121$ & 415.20 & 14.3 & 49.5 & 0.19 & 100 & 170.3 & 61.6 & 0.24 & $\mathrm{~N}$ & 2 & 3 \\
\hline $30-3,99-101$ & 416.50 & 147.1 & 55.3 & 0.37 & 100 & 172.9 & 60.2 & 0.24 & $\mathrm{~N}$ & 2 & 3 \\
\hline $30-4,19-21$ & 417.20 & 35.7 & 59.4 & 0.40 & 100 & 191.2 & 59.4 & 0.19 & $\mathrm{~N}$ & 2 & 3 \\
\hline $30-4,136-138$ & 418.37 & 12.0 & 50.6 & 0.45 & 100 & 350.8 & 67.4 & 0.27 & $\mathrm{~N}$ & 2 & 3 \\
\hline $30-5,18-20$ & 418.69 & 244.3 & 63.3 & 0.31 & 100 & 223.3 & 59.2 & 0.20 & $\mathrm{~N}$ & 2 & 2 \\
\hline $30-5,117-119$ & 419.68 & 140.8 & 71.1 & 0.35 & 100 & 155.1 & 56.3 & 0.29 & $\mathrm{~N}$ & 2 & 2 \\
\hline $31-1,44-46$ & 422.45 & 350.0 & 44.3 & 0.45 & 100 & 343.1 & 44.8 & 0.34 & $\mathrm{~N}$ & 2 & 2 \\
\hline $31-2,115-117$ & 424.66 & 346.7 & 39.4 & 0.45 & 100 & 338.1 & 46.2 & 0.28 & $\mathrm{~N}$ & 2 & 2 \\
\hline $31-3,17-19$ & 425.18 & 45.6 & 50.9 & 0.41 & 100 & 65.5 & 45.9 & 0.21 & $\mathrm{~N}$ & 2 & 3 \\
\hline $31-4,8-10$ & 426.59 & 66.3 & 43.7 & 0.42 & 100 & 58.5 & 45.7 & 0.35 & $\mathrm{~N}$ & 2 & 2 \\
\hline $31-5,21-23$ & 428.22 & 314.9 & 24.3 & 0.53 & 100 & 291.4 & 36.1 & 0.23 & $\mathrm{~N}$ & 2 & 2 \\
\hline $31-6,24-26$ & 429.75 & 322.7 & 45.7 & 0.76 & 100 & 328.7 & 54.2 & 0.26 & $\mathrm{~N}$ & 2 & 2 \\
\hline $32-1,24-26$ & 431.75 & 298.0 & 49.3 & 0.54 & 100 & 299.2 & 51.3 & 0.31 & $\mathrm{~N}$ & 2 & 2 \\
\hline $32-2,49-51$ & 433.50 & 29.3 & 38.2 & 0.56 & 100 & 29.3 & 54.0 & 0.28 & $\mathrm{~N}$ & 2 & 2 \\
\hline $32-3,16-18$ & 434.67 & 16.9 & 36.9 & 0.58 & 100 & 30.1 & 55.1 & 0.42 & $\mathrm{~N}$ & 2 & 3 \\
\hline $32-4,18-20$ & 436.19 & 24.5 & 58.3 & 0.49 & 100 & 56.7. & 58.7 & 0.32 & $\mathrm{~N}$ & 2 & 3 \\
\hline
\end{tabular}


TABLE 3 - Continued

\begin{tabular}{|c|c|c|c|c|c|c|c|c|c|c|c|}
\hline \multirow{2}{*}{$\begin{array}{c}\text { Sample } \\
\text { (Interval in } \mathrm{cm} \text { ) }\end{array}$} & \multirow[b]{2}{*}{ Depth } & \multirow[b]{2}{*}{ Dec. } & \multirow{2}{*}{$\begin{array}{l}\text { NRM } \\
\text { Inc. }\end{array}$} & \multirow[b]{2}{*}{ Int. } & \multirow{2}{*}{$\begin{array}{l}\text { Demag. } \\
\text { Field }\end{array}$} & \multicolumn{3}{|c|}{ After Demagnetization } & \multirow[b]{2}{*}{ Polarity } & \multicolumn{2}{|c|}{ Category $^{\mathrm{a}}$} \\
\hline & & & & & & Dec. & Inc. & Int. & & Polarity & Direction \\
\hline $32-5,40-42$ & 437.91 & 323.8 & 39.6 & 0.73 & 100 & 321.9 & 41.6 & 0.40 & $\mathrm{~N}$ & 2 & 2 \\
\hline $32-6,148-150$ & 440.49 & 331.1 & 53.6 & 0.68 & 100 & 317.6 & 41.4 & 0.31 & $\mathrm{~N}$ & 2 & 3 \\
\hline $33-1,93-95$ & 441.94 & 324.2 & -41.3 & 0.40 & 100 & 319.4 & -42.1 & 0.27 & $\mathrm{R}$ & 2 & 2 \\
\hline $33-1,124-126$ & 442.25 & 349.2 & -49.9 & 0.49 & 100 & 355.5 & -54.2 & 0.28 & $\mathrm{R}$ & 2 & 2 \\
\hline $33-1,131-133$ & 442.32 & 28.2 & -52.9 & 0.54 & 100 & 349.9 & -54.6 & 0.39 & $\mathrm{R}$ & 2 & 2 \\
\hline $33-1,136-138$ & 442.37 & 341.4 & -51.5 & 0.34 & 100 & 356.3 & -60.0 & 0.35 & $\mathrm{R}$ & 2 & 2 \\
\hline $33-2,11-13$ & 442.62 & 88.0 & 65.5 & 0.34 & 100 & 106.6 & 58.2 & 0.48 & $\mathrm{~N}$ & 2 & 3 \\
\hline $33-2,88-90$ & 443.39 & 26.6 & 50.6 & 0.40 & 100 & 50.9 & 49.4 & 0.25 & $\mathrm{~N}$ & 2 & 3 \\
\hline $33-3,143-145$ & 445.44 & 18.6 & 62.2 & 0.18 & 100 & 61.1 & 40.0 & 0.12 & $\mathrm{~N}$ & 2 & 3 \\
\hline $33-4,31-33$ & 445.82 & 85.0 & 60.2 & 0.15 & 100 & 86.4 & 55.6 & 0.15 & $\mathrm{~N}$ & 2 & 2 \\
\hline $33-5,91-93$ & 447.92 & 67.3 & 62.5 & 0.22 & 100 & 116.8 & 57.9 & 0.16 & $\mathrm{~N}$ & 2 & 3 \\
\hline $33-6,107-109$ & 449.58 & 8.2 & 47.4 & 0.26 & 300 & 77.3 & 16.8 & 0.10 & $\mathrm{~N}$ & 2 & 3 \\
\hline $34-1,30-32$ & 450.81 & 309.0 & 35.6 & 0.13 & 100 & 319.1 & 42.3 & 0.16 & $\mathrm{~N}$ & 2 & 3 \\
\hline $34-2,32-34$ & 452.33 & 14.1 & 50.6 & 0.22 & 100 & 329.4 & 52.6 & 0.12 & $\mathrm{~N}$ & 2 & 3 \\
\hline $34-3,27-29$ & 453.78 & 22.0 & 17.3 & 0.14 & 100 & 345.9 & 58.6 & 0.09 & $\mathrm{~N}$ & 2 & 3 \\
\hline $34-4,7-9$ & 455.09 & 0.6 & 48.6 & 0.15 & 100 & 10.3 & 57.6 & 0.12 & $\mathrm{~N}$ & 2 & 2 \\
\hline $35-1,58-60$ & 460.59 & 196.5 & 50.0 & 0.20 & 300 & 4.5 & 54.0 & 0.11 & $\mathrm{~N}$ & 2 & 3 \\
\hline $35-2,25-27$ & 461.76 & 72.3 & 69.0 & 0.17 & 300 & 178.3 & 82.2 & 0.15 & $\mathrm{~N}$ & 2 & 3 \\
\hline $35-3,71-73$ & 463.72 & 127.4 & 47.6 & 0.21 & 300 & 158.3 & 36.8 & 0.12 & $\mathrm{~N}$ & 2 & 3 \\
\hline $35-4,29-31$ & 464.80 & 323.9 & 45.6 & 0.40 & 300 & 32.8 & 52.4 & 0.12 & $\mathrm{~N}$ & 2 & 3 \\
\hline $35-5,65-67$ & 466.66 & 278.7 & 42.5 & 0.47 & 100 & 311.3 & 53.9 & 0.30 & $\mathrm{~N}$ & 2 & 3 \\
\hline
\end{tabular}

${ }^{\text {a }}$ See note to Table 1 for explanation.

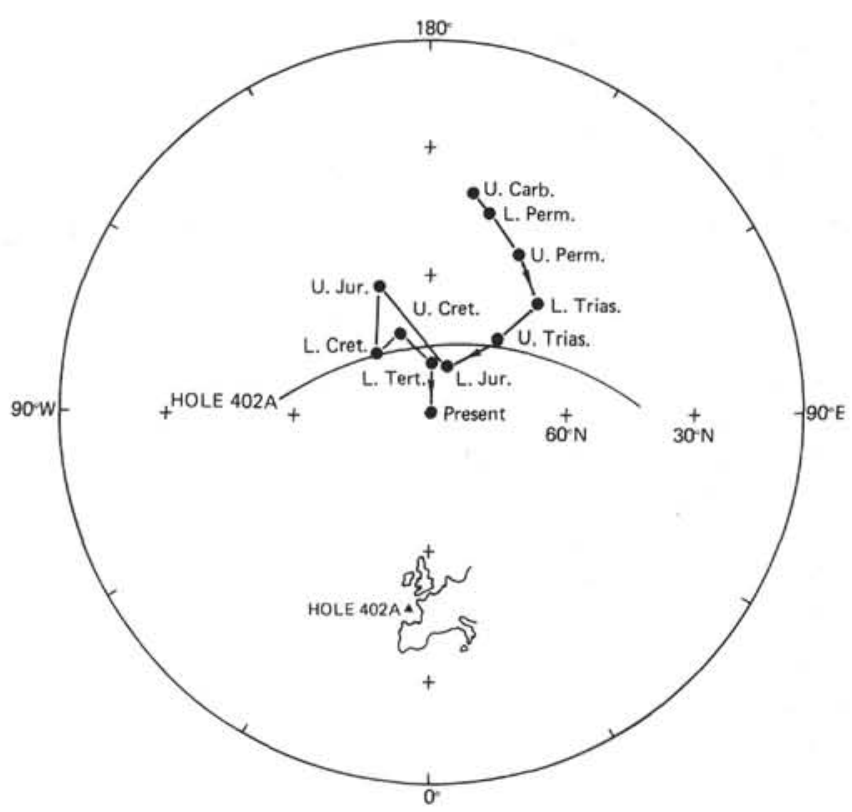

Figure 13. Post-upper Carboniferous polar wander curve for western Europe (heavy line), and pole position locus for Early Cretaceous black shales from Hole 402 (thinline).

original stable shipboard direction and intensity could be retrieved by shore-laboratory demagnetization at $300 \mathrm{Oe}$ (Figure 15).

Sample 34-4, 116-118 cm is an example of a sediment of which the direction of stable magnetization appears to have changed by a significant amount (approximately $35^{\circ}$ ) between treatment at $500 \mathrm{Oe}$ on the ship, and at 500 and $600 \mathrm{Oe}$ in the shore laboratory some five months later. Approximately 10 per cent of the samples from Site 403 exhibited this type of behavior, which probably represents the acquisition of a stable CRM resulting from dehydration and chemical alteration during storage.

Sample 34-2, 132-134 cm (Figure 15) represents a case in which a stable end point was not achieved by demagnetization at $300 \mathrm{Oe}$ on the ship. Subsequently shore-laboratory treatment at 300 Oe results in a closely similar direction to the shipboard 300 Oe value, but the directional trend continues during further treatment to $500 \mathrm{Oe}$, after which a relatively stable end point appears to have been reached. The validity of this table end point is supported by the fact that the adjacent sample, $34-2,30-32 \mathrm{~cm}$, from the same core section, maintains a similar declination and inclination during treatment at $300 \mathrm{Oe}$ and above. The similarity of declination values implies the absence of relative core rotation ('disking") between these two samples. Similar declination values are also observed for the two samples from Core 34, Section 3 (Figure 14b).

2) Magnetic polarity stratigraphy for Site 403: Although 50 per cent of the samples exhibited an NRM with a normal polarity, AF demagnetization revealed the presence of an underlying stable magnetization of reverse polarity in all Paleocene and Eocene samples from Site 403 (Figure 16, left-hand column). The significance of this result is discussed in the final section of this paper.

\section{Paleomagnetic Results From Site 404}

At Site 404 the same series of middle to lower Eocene glauconitic mudstones and tuffs was encountered as at Site 403. Site 404 polarity stratigraphy is summarized in Figure 16. As with Site 403, partial demagnetization at 200 Oe was found sufficient to confidently define the polarity of a high proportion of samples, but in many cases treatment at higher fields was necessary. Whereas at Site 403 , all samples measured within the NP 10 to NP 12 nannofossil zones had reverse magnetic polarity, at Site 404 two clearly defined normal polarity zones are present, in Cores 10-11 and 15-16, 
respectively. A further four possible thin normal polarity zones, each defined by a single sample, are present in Cores $17,18,22$, and 23 (Table 5). The reliability of these polarity determinations is assessed in the ensuing discussion, and their significance discussed in the final section of the paper.

Examples of the response to AF demagnetization of five samples of reverse polarity from this site are shown in Figure 17. Many samples acquired significant secondary components of magnetization between initial measurement on the ship, and remeasurement in the shore-laboratory several months later, but in most cases (e.g., Samples 7-2, 95-97 $\mathrm{cm}$ and 7-2, 118-120 cm, Figure 17) the direction isolated after 200 Oe treatment on the ship was retrieved after treatment at 300 to $500 \mathrm{Oe}$ in the shore laboratory. However, occasional samples showed poorer agreement between the shipboard and shore-laboratory measurements, and a few samples, such as 8-2, $15-17 \mathrm{~cm}$, showed erratic and apparently unstable behavior after treatment at high applied fields so that a stable end point could not be reliably defined. Many samples, e.g., 8-1, 46-48 cm, carry a strong normal polarity overprint, and in this particular example the resultant intensity of magnetization drops to zero after treatment at 200 $\mathrm{Oe}$, when the normal and reverse components are approximately equal and opposite in magnitude. Further treatment at 500 Oe removes the secondary normal component, and the resultant direction of magnetization is similar to that obtained after shore-laboratory treatment at 500 and 600 Oe (Figure 17).

The stability behavior of the four samples defining the possible thin normal zones in Cores 17, 18, 22, and 23 is illustrated in Figure 15a. In three out of the four samples the positive inclination of the remanence vectors showed a progressive decrease in magnitude during treatment up to 500 Oe at which point the intensity had decreased to about 10 per cent of the NRM value. Subsequent treatment at higher applied fields resulted in erratic directional response. This behavior suggests the possible presence of a component of reverse polarity, masked by a normal polarity component which resides in grains of both similar and slightly lower coercivities than the reverse polarity component. During AF treatment up to 500 Oe both components are progressively demagnetized, but removal of the lower coercivity normal polarity component is slightly preferential. This results in the partial unmasking of the reverse polarity component after treatment at 500 Oe, but by 600 Oe both components appear to have been totally removed or reduced to a value below the instrument noise level. The ensuing erratic movements then represent either viscous behavior or instrumental noise.

The two longer intervals of normal polarity, identified in Cores 10-11 and 15-16, are defined by three samples and five samples, respectively. The demagnetization behavior of one sample from the upper normal interval is illustrated in Figure $15 \mathrm{~b}$ (Sample 404-10-1, $81 \mathrm{~cm}$ ). This sample maintains a high positive inclination, close to the theoretical axial geocentric dipole value, after demagnetization at 200 and $500 \mathrm{Oe}$, and thus appears to carry only a single normal polarity component. The paleomagnetic data from the five samples within the lower normal interval are also plotted on this diagram, and in all cases a significant reduction in inclination occurs after treatment at $200 \mathrm{Oe}$, followed by little change up to $700 \mathrm{Oe}$. This may be interpreted as due to the removal of a steeply inclined secondary component of magnetization, possibly acquired during drilling, superimposed on a primary component with shallower inclination, but still having a normal polarity. It is concluded that the two longer intervals of positive inclination at Site 404 represent real episodes of normal polarity of the geomagnetic field, rather than simply normal polarity overprints acquired in the present field.

\section{Magnetic Intensities and Susceptibilities}

The downhole susceptibility and NRM intensity records for Sites 403 and 404 are compared in Figure 18, and at both sites two clearly defined peaks may be identified in these two parameters. At each of these sites the uppermost peak lies within nannofossil Zone NP 11, and dinocyst Zone Ib. Similarly the lower peak occurs near the base of dinocyst Zone Ia. This suggests that the two magnetic peaks represent a pair of synchronous events at the two sites. The upper event appears to correlate with a discrete volcanic tuff layer, and the lower event with the middle of a thick sequence of tuffs at both sites ( $R$. Harrison, this volume). These magnetic peaks probably represent tuffaceous layers that are particularly enriched in magnetite. Such temporal variations in magnetic composition also characterize the East Greenland basalts (Hailwood, Løvlie, and Tarling, in preparation), and in the present case provide useful stratigraphic markers for correlation between the sedimentary records of Sites 403 and 404.

\section{Site $\mathbf{4 0 5}$}

Site 405 was drilled at the western end of the transform-fault-controlled southern margin of the Rockall Plateau. At this site a thick early to middle Eocene sequence of calcareous and siliceous mudstones was cored, and the paleomagnetic polarity determinations for this sequence are shown in the right-hand column of Figure 16.

\section{Paleomagnetic Stability Tests for Site 405}

The demagnetization behavior of representative samples from each of the important normal and reverse polarity intervals at Site 405 is shown in Figure 19. Sample 10-1, $58-60 \mathrm{~cm}$ (Table 6), from the upper reverse polarity interval, carries a small low-coercivity component which is removed by $\mathrm{AF}$ treatment at $50 \mathrm{Oe}$, after which a well-defined direction with a negative inclination is maintained on further treatment to 300 Oe. Likewise, Samples $14-3,6-8 \mathrm{~cm}$, and 19-1, $108-110 \mathrm{~cm}$, from the upper normal polarity interval maintain well-defined directions with a positive inclination after AF demagnetization at 100 and 300 Oe. The negative inclination identified by shipboard treatment at 300 Oe for Sample $31-1,18-20 \mathrm{~cm}$, from the reverse polarity interval of Core 31 is confirmed by shore-laboratory treatment up to 500 Oe. Unfortunately only 50 per cent of the samples from the lower dominantly normal polarity interval of Cores 32 to 39 show well-defined stable end points. For example, Sample 33-1, 103-105 cm has a well-defined direction of stable remanence, revealed by both shipboard and shore-laboratory treatment up to 500 Oe. Similarly, Sample 36-1, 129-131 $\mathrm{cm}$, appears to approach a stable end point after shipboard treatment at $500 \mathrm{Oe}$, and a similar direction is revealed by shore-laboratory treatment at $700 \mathrm{Oe}$. However, the 
TABLE 4

Site 403: Paleomagnetic Results

\begin{tabular}{|c|c|c|c|c|c|c|c|c|c|c|c|}
\hline \multirow{2}{*}{$\begin{array}{c}\text { Sample } \\
\text { (Interval in } \mathrm{cm} \text { ) }\end{array}$} & \multirow[b]{2}{*}{ Depth } & \multirow[b]{2}{*}{ Dec. } & \multirow{2}{*}{$\begin{array}{l}\text { NRM } \\
\text { Inc. }\end{array}$} & \multirow[b]{2}{*}{ Int. } & \multirow{2}{*}{$\begin{array}{c}\text { Demag. } \\
\text { Field }\end{array}$} & \multicolumn{3}{|c|}{ After Demagnetization } & \multirow[b]{2}{*}{ Polarity } & \multicolumn{2}{|c|}{ Category $^{\mathrm{a}}$} \\
\hline & & & & & & Dec. & Inc. & Int. & & Polarity & Direction \\
\hline $25-2,51-53$ & 234.52 & 329.2 & -71.5 & 2.11 & 300 & 332.9 & -63.5 & 1.84 & $\mathrm{R}$ & 1 & 2 \\
\hline $25-2,97-99$ & 234.98 & 107.7 & 66.6 & 10.36 & 300 & 123.2 & 70.3 & 2.25 & $\mathrm{~N}$ & 2 & 3 \\
\hline $27-1,11-13$ & 242.12 & 298.7 & 53.2 & 1.33 & 300 & 316.3 & -55.0 & 0.99 & $\mathrm{R}$ & 1 & 2 \\
\hline $28-1,14-16$ & 251.65 & 50.5 & 3.7 & 16.95 & 300 & 58.0 & -46.0 & 13.96 & $\mathrm{R}$ & 1 & 2 \\
\hline $28-1,75-77$ & 252.25 & 138.1 & 49.5 & 8.12 & 300 & 102.4 & -32.5 & 6.48 & $\mathrm{R}$ & 1 & 2 \\
\hline $29-1,26-28$ & 261.27 & 252.8 & 43.1 & 26.01 & 500 & 291.7 & -82.2 & 14.92 & $\mathrm{R}$ & 1 & 2 \\
\hline $29-1,31-33$ & 262.11 & 235.1 & 18.1 & 17.32 & 500 & 341.2 & -57.9 & 21.40 & $\mathrm{R}$ & 1 & 2 \\
\hline $29-1,110-112$ & 261.32 & 8.4 & 30.3 & 15.94 & 500 & 304.9 & -52.5 & 11.90 & $\mathrm{R}$ & 1 & 3 \\
\hline $29-3,66-68$ & 264.67 & 296.4 & 70.1 & 33.56 & 300 & 248.9 & -72.6 & 9.90 & $\mathrm{R}$ & 1 & 3 \\
\hline $29-4,56-58$ & 266.07 & 68.8 & 69.1 & 186.47 & 750 & 313.8 & -31.1 & 15.98 & $\mathrm{R}$ & 2 & 3 \\
\hline $29-4,121-123$ & 266.72 & 31.3 & 71.7 & 221.90 & 750 & 3.8 & -19.1 & 23.07 & $\mathrm{R}$ & 1 & 3 \\
\hline $29-5,40-42$ & 267.41 & 276.9 & 74.1 & 93.80 & 500 & 220.9 & -26.7 & 25.82 & $\mathrm{R}$ & 1 & 3 \\
\hline $29-5,87-89$ & 267.88 & 267.7 & 8.8 & 45.05 & 300 & 213.4 & -52.9 & 50.48 & $\mathrm{R}$ & 1 & 3 \\
\hline $30-1,10-12$ & 270.61 & 346.9 & 46.7 & 42.97 & 750 & 198.0 & -36.5 & 11.81 & $\mathrm{R}$ & 1 & 3 \\
\hline $30-1,51-53$ & 271.02 & 31.6 & 69.4 & 62.16 & 500 & 353.9 & -20.9 & 11.50 & $\mathrm{R}$ & 1 & 3 \\
\hline $34-1,59-61$ & 309.10 & 156.0 & 76.7 & 8.97 & 500 & 3.1 & -2.2 & 1.65 & $\mathrm{R}$ & 2 & 3 \\
\hline $34-1,127-129$ & 309.78 & 259.6 & 71.9 & 6.57 & 500 & 1.0 & -19.4 & 1.04 & $\mathrm{R}$ & 2 & 3 \\
\hline $34-2,30-32$ & 310.31 & 287.3 & 86.2 & 3.81 & 500 & 15.3 & -6.3 & 0.42 & $\mathrm{R}$ & 2 & 3 \\
\hline $34-2,132-134$ & 311.33 & 284.7 & 60.6 & 1.84 & 500 & 339.6 & -44.4 & 0.52 & $\mathrm{R}$ & 2 & 3 \\
\hline $34-3,45-47$ & 311.96 & 117.0 & -48.2 & 12.52 & 300 & 147.2 & -58.1 & 12.98 & $\mathrm{R}$ & 1 & 1 \\
\hline $34-7,118-120$ & 312.69 & 108.6 & -62.8 & 11.43 & 300 & 115.6 & -60.3 & 11.73 & $\mathrm{R}$ & 1 & 1 \\
\hline $34-4,40-42$ & 313.41 & 6.7 & 0.9 & 19.38 & 300 & 36.9 & -46.3 & 2.06 & $\mathrm{R}$ & & \\
\hline $34-4,116-118$ & 314.17 & 220.3 & -35.3 & 16.94 & 500 & 268.3 & -57.8 & 6.73 & $\mathrm{R}$ & 1 & 1 \\
\hline $34-5,50-52$ & 315.03 & 36.5 & -41.4 & 25.60 & 300 & 63.5 & -60.5 & 7.69 & $\mathrm{R}$ & & \\
\hline $34-5,112-124$ & 315.73 & 196.1 & -34.9 & 33.03 & 500 & 200.3 & -63.0 & 9.02 & $\mathrm{R}$ & 1 & 1 \\
\hline $34-6,18-20$ & 316.19 & 309.9 & -57.2 & 17.69 & 500 & 329.7 & -52.5 & 9.52 & $\mathrm{R}$ & 1 & 1 \\
\hline $35-1,10-12$ & 318.11 & 149.0 & -23.4 & 23.09 & 500 & 155.9 & -59.7 & 9.97 & $\mathrm{R}$ & 1 & 2 \\
\hline $35-1,71-73$ & 318.70 & 299.2 & -39.4 & 11.79 & 300 & 277.7 & -64.0 & 10.23 & $\mathrm{R}$ & 1 & 2 \\
\hline $35-2,79-81$ & 320.30 & 148.0 & -18.2 & 37.25 & 200 & 85.2 & -55.8 & 13.44 & $\mathrm{R}$ & 1 & 1 \\
\hline $35-2,110-112$ & 321.34 & 341.6 & -15.9 & 55.07 & 300 & 308.6 & -53.9 & 12.32 & $\mathrm{R}$ & 1 & 1 \\
\hline $35-3,33-35$ & 322.67 & 212.5 & -20.7 & 19.27 & 200 & 227.7 & -52.0 & 14.31 & $\mathrm{R}$ & 1 & 1 \\
\hline $35-3,83-85$ & 323.17 & 22.4 & -69.9 & 16.05 & 300 & 179.4 & -54.5 & 13.05 & $\mathrm{R}$ & 1 & 1 \\
\hline $35-4,16-18$ & 322.67 & 143.8 & -14.5 & 3.78 & 200 & 47.9 & -51.2 & 2.83 & $\mathrm{R}$ & 1 & 3 \\
\hline $35-4,63-65$ & 323.14 & 225.4 & 35.5 & 1.79 & 200 & 277.2 & -57.5 & 2.66 & $\mathrm{R}$ & 1 & 1 \\
\hline $36-1,10-21$ & 327.70 & 165.7 & 9.2 & 11.33 & 200 & 116.9 & -34.6 & 4.97 & $\mathrm{R}$ & 1 & 1 \\
\hline $36-1,107-109$ & 328.58 & 358.6 & -6.2 & 17.12 & 300 & 331.6 & -41.8 & 3.16 & $\mathrm{R}$ & 1 & 1 \\
\hline $36-2,17-19$ & 329.18 & 170.6 & -10.1 & 11.77 & 200 & 130.6 & -42.6 & 3.09 & $\mathrm{R}$ & 1 & 1 \\
\hline $36-2,43-45$ & 329.44 & 4.8 & -34.3 & 42.08 & 300 & 4.2 & -44.4 & 14.79 & $\mathrm{R}$ & 1 & 1 \\
\hline $37-1,15-17$ & 337.16 & 83.9 & -45.1 & 10.88 & 200 & 82.8 & -57.3 & 9.90 & $\mathrm{R}$ & 1 & 1 \\
\hline $37-1,58-60$ & 337.59 & 349.2 & -32.8 & 41.84 & 300 & 339.7 & -59.9 & 17.28 & $\mathrm{R}$ & 1 & 1 \\
\hline $37-2,21-23$ & 338.72 & 281.6 & -59.2 & 23.96 & 200 & 319.9 & -64.2 & 12.34 & $\mathrm{R}$ & 1 & 3 \\
\hline $37-2,95-97$ & 339.46 & 173.5 & -25.0 & 13.03 & 300 & 323.7 & -70.0 & 11.12 & $\mathrm{R}$ & 1 & 2 \\
\hline $37-3,43-45$ & 340.44 & 321.1 & 80.6 & 0.43 & 200 & 26.5 & -57.6 & 1.37 & $\mathrm{R}$ & 1 & 1 \\
\hline $37-3,86-88$ & 340.87 & 195.7 & 11.6 & 1.94 & 300 & 293.0 & -58.3 & 1.20 & $\mathrm{R}$ & 1 & 2 \\
\hline $37-4,69-71$ & 342.20 & 145.5 & -27.0 & 1.36 & 200 & 156.3 & -63.2 & 2.96 & $\mathrm{R}$ & 1 & 3 \\
\hline $37-4,102-104$ & 342.53 & 321.6 & -45.8 & 3.70 & 300 & 254.9 & -58.5 & 2.07 & $\mathrm{R}$ & 1 & 1 \\
\hline $37-5,50-52$ & 343.51 & 170.0 & -27.4 & 1.88 & 300 & 170.2 & -38.0 & 1.75 & $\mathrm{R}$ & 1 & 1 \\
\hline $37-5,120-122$ & 344.21 & 196.3 & -2.2 & 1.72 & 200 & 191.4 & -34.8 & 1.56 & $\mathrm{R}$ & 1 & 1 \\
\hline $38-1,6-8$ & 346.57 & 144.3 & 4.1 & 1.66 & 200 & 125.0 & -70.3 & 2.47 & $\mathrm{R}$ & 1 & 1 \\
\hline $38-2,148-50$ & 349.49 & 283.0 & -68.4 & 1.15 & 200 & 331.8 & -60.1 & 0.94 & $\mathrm{R}$ & 1 & 1 \\
\hline $38-3,46-48$ & 349.97 & 5.8 & -13.2 & 4.31 & 300 & 9.3 & -30.8 & 1.85 & $\mathbf{R}$ & 1 & 1 \\
\hline $38-3,121-123$ & 350.72 & 252.7 & -9.3 & 1.15 & 200 & 229.7 & -41.4 & 1.36 & $\mathrm{R}$ & 1 & 3 \\
\hline $38-4,56-58$ & 351.57 & 166.6 & -45.7 & 2.67 & 200 & 159.0 & -65.5 & 1.33 & $\mathrm{R}$ & 1 & 3 \\
\hline $38-4,81-83$ & 351.82 & 41.3 & -65.1 & 2.87 & 300 & 192.2 & -65.5 & 2.53 & $\mathrm{R}$ & 1 & 2 \\
\hline $39-1,121-123$ & 357.22 & 150.8 & -63.3 & 53.77 & 200 & 146.1 & -63.7 & 45.14 & $\mathrm{R}$ & 1 & 1 \\
\hline $39-2,69-71$ & 358.20 & 350.4 & -41.8 & 67.77 & 300 & 350.2 & -59.0 & 35.76 & $\mathrm{R}$ & 1 & 1 \\
\hline $39-2,128-130$ & 358.79 & 249.1 & -58.8 & 47.36 & 200 & 246.9 & -59.6 & 52.09 & $\mathrm{R}$ & 1 & 1 \\
\hline $39-3,22-24$ & 359.23 & 271.0 & -30.9 & 10.52 & 300 & 127.3 & -65.3 & 27.27 & $\mathrm{R}$ & 1 & 1 \\
\hline $39-3,60-62$ & 359.61 & 1.3 & -33.3 & 79.83 & 200 & 226.7 & -68.5 & 21.67 & $\mathrm{R}$ & 1 & 3 \\
\hline $40-1,33-35$ & 365.84 & 193.5 & 66.2 & 217.68 & 750 & 176.8 & -25.2 & 32.12 & $\mathrm{R}$ & 1 & 3 \\
\hline $40-1,103-105$ & 366.54 & 33.8 & -65.1 & 28.61 & 300 & 91.3 & -71.5 & 19.66 & $\mathrm{R}$ & 1 & 1 \\
\hline $40-2,58-60$ & 367.59 & 75.8 & -45.3 & 12.38 & 200 & 74.5 & -60.0 & 11.19 & $\mathrm{R}$ & 1 & 1 \\
\hline $40-2,141-143$ & 368.42 & 17.3 & 4.4 & 47.32 & 300 & 269.3 & -73.1 & 10.45 & $\mathrm{R}$ & 1 & 3 \\
\hline $40-3,24-26$ & 368.75 & 338.5 & -18.3 & 37.95 & 200 & 298.2 & -58.5 & 33.56 & $\mathrm{R}$ & 1 & 3 \\
\hline $40-3,108-110$ & 369.59 & 342.0 & 49.6 & 27.33 & 200 & 338.3 & -31.2 & 8.92 & $\mathrm{R}$ & 1 & 3 \\
\hline $41-1,48-50$ & 375.49 & 68.4 & -64.1 & 8.66 & 200 & 44.9 & -59.3 & 22.39 & $\mathbf{R}$ & 1 & 2 \\
\hline $41-1,132-134$ & 376.33 & 355.3 & -10.7 & 125.88 & 300 & 3.2 & -40.4 & 18.24 & $\mathrm{R}$ & 1 & 1 \\
\hline
\end{tabular}


TABLE 4 - Continued

\begin{tabular}{|c|c|c|c|c|c|c|c|c|c|c|c|}
\hline \multirow{2}{*}{$\begin{array}{c}\text { Sample } \\
\text { (Interval in } \mathrm{cm} \text { ) }\end{array}$} & \multirow[b]{2}{*}{ Depth } & \multirow[b]{2}{*}{ Dec. } & \multirow{2}{*}{$\begin{array}{l}\text { NRM } \\
\text { Inc. }\end{array}$} & \multirow[b]{2}{*}{ Int. } & \multirow{2}{*}{$\begin{array}{l}\text { Demag. } \\
\text { Field }\end{array}$} & \multicolumn{3}{|c|}{ After Demagnetization } & \multirow[b]{2}{*}{ Polarity } & \multicolumn{2}{|c|}{ Category $^{\mathrm{a}}$} \\
\hline & & & & & & Dec. & Inc. & Int. & & Polarity & Direction \\
\hline $41-2,19-21$ & 376.70 & 113.1 & 53.7 & 20.19 & 200 & 6.7 & -79.6 & 5.71 & $\mathrm{R}$ & 1 & 3 \\
\hline $41-2,136-138$ & 377.87 & 2.7 & -10.0 & 180.85 & 300 & 349.9 & -45.5 & 32.24 & $\mathrm{R}$ & 1 & 2 \\
\hline $41-3,28-30$ & 378.29 & 149.9 & 1.2 & 76.88 & 200 & 132.2 & -51.5 & 28.92 & $\mathrm{R}$ & 1 & 3 \\
\hline $41-3,90-92$ & 378.91 & 91.5 & -28.1 & 34.79 & 200 & 69.7 & -59.7 & 21.89 & $\mathrm{R}$ & 1 & 2 \\
\hline $41-4,28-30$ & 379.79 & 342.2 & -56.7 & 48.83 & 300 & 340.5 & -61.2 & 16.43 & $\mathrm{R}$ & 1 & 2 \\
\hline $41-4,87-89$ & 380.38 & 177.7 & 9.6 & 18.60 & 200 & 155.2 & -40.7 & 17.49 & $\mathrm{R}$ & 2 & 3 \\
\hline $42-1,9-11$ & 384.60 & 171.3 & 56.0 & 40.94 & 750 & 32.2 & -41.9 & 4.72 & $\mathrm{R}$ & 2 & 3 \\
\hline $42-1,48-50$ & 384.99 & 171.9 & -6.7 & 91.58 & 200 & 165.3 & -24.2 & 35.00 & $\mathrm{R}$ & 1 & 3 \\
\hline $42-2,86-88$ & 386.87 & 308.1 & 56.6 & 17.01 & 200 & 294.4 & -43.9 & 10.51 & $\mathrm{R}$ & 1 & 2 \\
\hline $42-2,124-126$ & 387.25 & 208.5 & -22.4 & 32.14 & 200 & 205.4 & -61.7 & 30.75 & $\mathrm{R}$ & 1 & 3 \\
\hline $42-3,38-40$ & 387.89 & 233.4 & 5.2 & 17.29 & 200 & 175.8 & -43.8 & 16.62 & $\mathrm{R}$ & 1 & 3 \\
\hline $42-3,90-92$ & 388.41 & 127.9 & -17.9 & 29.76 & 200 & 105.9 & -55.3 & 23.68 & $\mathrm{R}$ & 1 & 3 \\
\hline $43-1,47-49$ & 394.58 & 19.1 & -33.5 & 19.88 & 200 & 133.9 & -66.4 & 10.85 & $\mathrm{R}$ & 1 & 3 \\
\hline $43-1,121-123$ & 395.22 & 183.7 & 7.1 & 18.02 & 200 & 144.6 & -50.5 & 6.69 & $\mathrm{R}$ & 1 & 3 \\
\hline $46-1,44-46$ & 422.95 & 283.5 & -45.2 & 90.80 & 200 & 289.4 & -48.9 & 79.51 & $\mathrm{R}$ & 1 & 1 \\
\hline
\end{tabular}

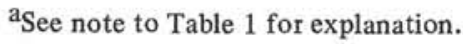

inclination of Samples 38-1, 17-19 cm, and 38-3, 52-54 cm, continues to decrease during treatment up to $700 \mathrm{oe}$, suggesting that a stable end point has not been reached. This behavior is typical of the majority of samples from Cores 36 , 38 , and 39 , and it is conceivable that the persistent movement towards shallow positive inclinations indicates a trend towards negative inclinations, so that an underlying reverse polarity component might be present. If this is the case, then the thickness of the lower dominantly normal polarity zone at Site 405 would be reduced from 80 meters to about 30 meters (Cores 32 to 34).

\section{Composite Magnetic Polarity Stratigraphy for Sites 403 to 405}

The magnetic polarity and biostratigraphic determinations for Sites 403 to 405 are summarized in Figure 16. Seismic profiles through this area indicate that the sediments immediately overlying anomaly 24 , some $30 \mathrm{~km}$ to the west of Sites 403 and 404 , correspond with a sub-bottom depth of about 250 to 300 meters at Site 404 (Roberts, this volume). Consequently the lower half of the Paleogene sedimentary sequence at this site must have been deposited immediately prior to anomaly 24 time. This part of the sequence is reversely magnetized throughout, and may be correlated biostratigraphically with early Eocene reverse polarity sediments at Site 403 that lie beneath the unconformity at 252 meters. It is concluded that the lower reverse polarity sediments at both sites were deposited during the long reverse polarity interval that preceded anomaly 24 .

It follows from the above discussion that the oldest normal polarity sediments encountered at Site 404 should correspond with anomaly 24 itself. These occur at a depth of about 280 meters, within dinocyst Zone II and at the base of nannofossil Zone NP 12, and the corresponding numeric age for the start of anomaly 24 is 52 million years on the Paleogene time scale of Berggren et al. (in preparation). Anomaly 24 consists of two separate normal polarity episodes (Heirtzler et al., 1968), designated $24 A$ and $24 B$ in Figure 16 , and comparison of the paleomagnetic data from all three DSDP Rockall sites suggests that the whole of the lower normal polarity interval at Site 404 may be correlated with anomaly
24B. At Site 405 the 80 -meter section of dominantly normal magnetic polarity within the NP 12 nannofossil zone is underlain by a clearly defined reverse polarity interval, also of NP 12 age. Consequently, it is believed to represent a separate and distinct magnetic anomaly to that identified at the base of nannofossil Zone NP 12 at Site 404, and is assigned to marine anomaly $24 A$.

Further intervals of normal polarity were identified at the top of nannofossil Zone NP 12 at Site 404, and in uppermost NP 12 and lowermost NP 13 sediments at Site 405. These normal polarity intervals are separated by sediments of clearly defined reverse polarity from the sediments assigned to anomaly $24 B$ at Site 404 , and those assigned to anomaly $24 A$ at Site 405 . Consequently, they are also considered to represent a separate magnetic anomaly, and are correlated with anomaly 23 . Finally, the thin normal polarity interval overlain by a longer reverse interval within the NP 14 nannofossil zone at Site 405 is tentatively correlated with the end of anomaly 22 . The composite magnetic polarity record representing anomalies 22 to 24 , derived by combining the paleomagnetic records from these three sites, is shown in the central column of Figure 16.

The age of 52 million years for anomaly 24 deduced from this study is significantly different from the value of 60 million years proposed by Heirtzler et al., and provides a key point in the calibration of the Paleogene polarity time scale (Hailwood et al., this volume). Since anomaly 24 is the oldest anomaly identified in the northeast Atlantic, and lies close to the present margins of East Greenland and Rockall, its age must correspond closely with the time of initiation of sea-floor spreading in the northeast Atlantic. The thick tuffaceous layers intercalated in the sediments of this age at Sites 403 to 404 signify the occurrence of an important episode of igneous activity, and it is highly probable that this represents the same magmatic event that gave rise to the reversely magnetized flood basalts of the East Greenland igneous province, which lay immediately adjacent to this margin of the Rockall Plateau prior to the initiation of sea-floor spreading. Paleontological studies of sediments which underlie, are interbedded with, and overlie the East Greenland basalts indicate that the entire pile was erupted 

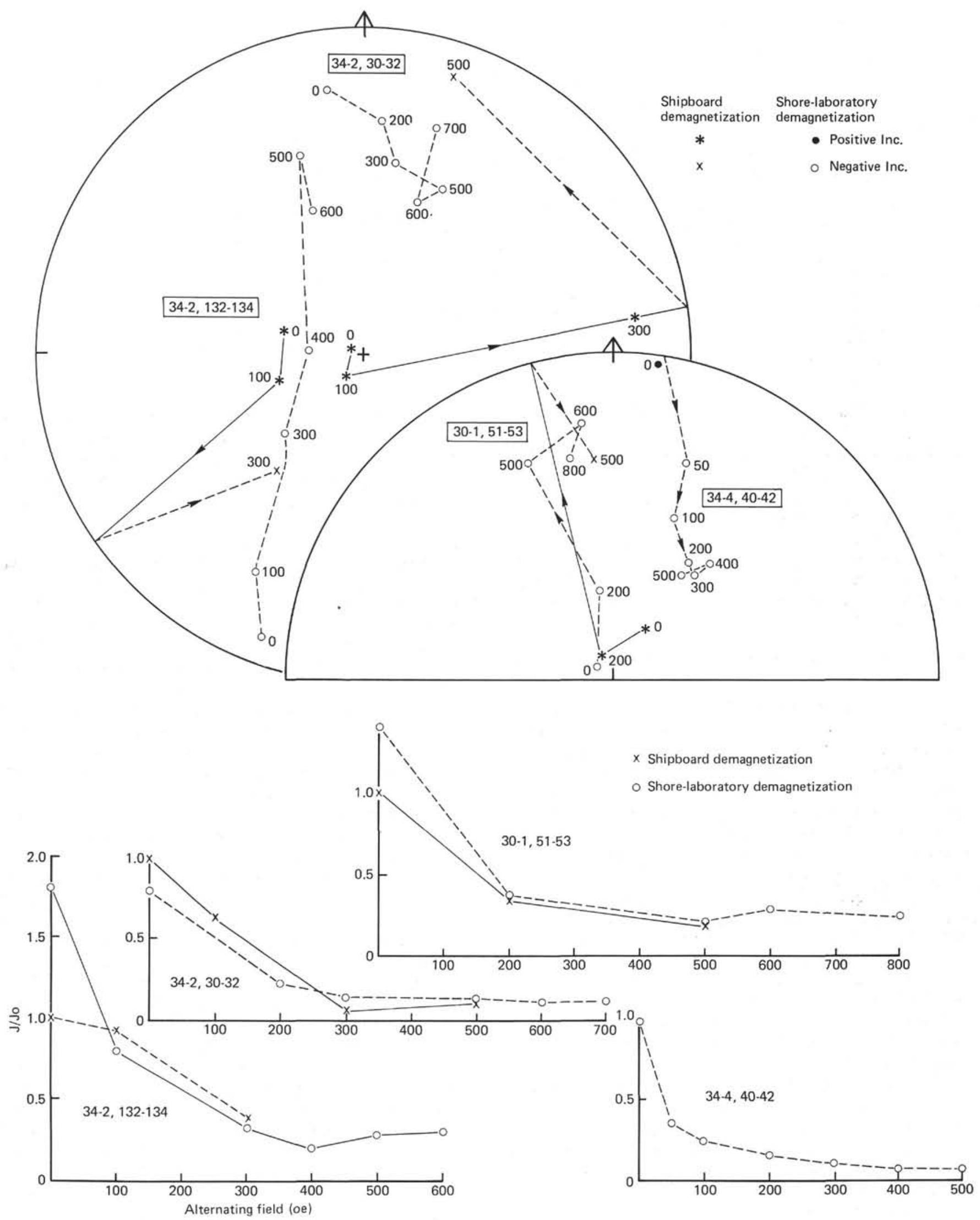

Figure 14. Examples of response to AF demagnetization of representative samples from Site 403. 

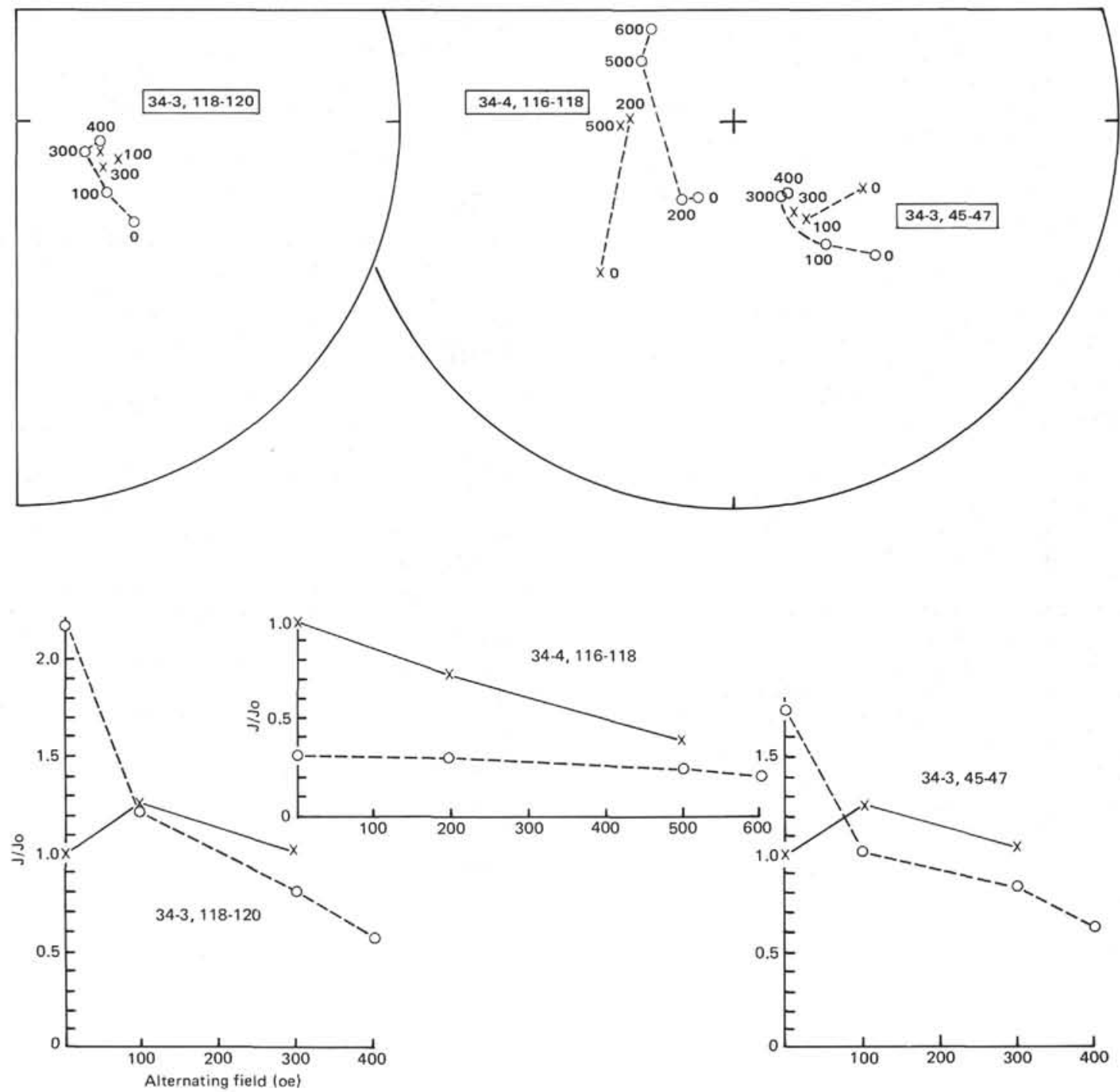

Figure 14. Continued.

within a maximum time interval of about 3 million years in latest Paleocene and earliest Eocene time (Soper et al., 1976). That these reversely magnetized basalts were erupted contemporaneously with the deposition of the reverse polarity tuffs and volcanogenic mudstones of Site 403 is indicated by palynological studies of sediments interbedded in the East Greenland basalts (Soper et al., 1976) and of the Site 403 sediments (Costa and Downie, this volume), both of which are assigned to dinocyst Zones Ia and $\mathrm{Ib}$.

\section{CONCLUSIONS}

The study has helped to demonstrate the potential value of shipboard sedimentary paleomagnetic investigations in providing the essential link between biostratigraphic and magnetic polarity time scales. Such information has obvious value in refining shipboard paleontological age determinations, as well as in providing an "absolute" calibration of the paleontological time scales. In the present study this has proved possible for the late Neogene and Pleistocene sediments at Hole 400A (Hailwood et al., this volume). Furthermore, correlation between the pattern of reversals observed in the vertical sedimentary sequences and the pattern of magnetic anomalies recorded horizontally in the underlying basaltic crust, provides the opportunity for detailed comparisons between the timing of major plate tectonic events, deduced from the magnetic anomaly patterns, and their geological manifestations in the sedimentary record. Thus the sequence of reversals identified in the early Paleogene sediments of Sites 403 to 405 (Rockall Plateau) show a good correlation with marine anomalies 24 to 22 , and allow geologic events recorded at specific levels in these cores to be attributed to tectonic processes operating during the early stages of opening of the northeast Atlantic.

\section{ACKNOWLEDGMENTS}

I would like to thank Bill Sayre and Pat Copland for their assistance with the shore-laboratory paleomagnetic measurements described in this paper, Joan Wedge for typing the manuscript and tables, and Angela Brady for drafting the figures. I am grateful to Carla Müller, Detmar Schnitker, Wayne Bock, and Pierre du Peuble for free access to the results of their paleontological studies, and for 
useful discussions throughout this work. I thank Norman Hamilton and Gerry Morgan for their critical review and helpful comments on the manuscript. Finally, the ability to complete the shipboard paleomagnetic measurements on some 750 samples during two months at sea was only possible through the close cooperation and assistance of the Co-Chief Scientists, Dave Roberts and Lucien Montadert, and the rest of the shipboard scientific and technical party, to whom I express my sincere thanks.

\section{REFERENCES}

Bonhommet, N. and Zahringer, J., 1969. Paleomagnetism and potassium argon age determinations of the Laschamp geomagnetic polarity event, Earth Planet. Sci. Lett., v. 6, p. 43-46.

Faller, A., 1975. Palaeomagnetism of the oldest Tertiary basalts in the Kangerdlugssuaq area of East Greenland, Geol. Soc. Denmark Bull., v. 24, p. 173-178.

Green, K.A. and Brecher, A., 1974. Preliminary paleomagnetic results for sediments from Site 263, Leg 27. In Heirtzler, J., Veevers, J., et al., Initial Reports of the Deep Sea Drilling Project, v. 27, Washington (U.S. Government Printing Office), p. 405-413.

Hailwood, E.A., 1977. Configuration of the geomagnetic field in early Tertiary times, J. Geol. Soc. London, v. 133, p. 23-26.

Hailwood, E.A., Tarling, D.H., Mitchell, J.G., and Løvlie, R., 1973. Preliminary observations on the palaeomagnetism and radiometric ages of the Tertiary basalt sequence of Scoresby Sund, East Greenland: Rapp. Gronlands geol. Unders., v. 58, p. 43-47.

Jarrard, R.D., 1974. Paleomagnetism of some Leg 27 sediment cores. In Heirtzler, J., Veevers, J., et al., Initial Reports of the
Deep Sea Drilling Project, v. 27, Washington (U.S. Government Printing Office), p. 415-423.

Keen, M.J., 1963. The magnetisation of sediment cores from the eastern basin of the North Atlantic Ocean, Deep-Sea Res., v. 10 , p. $607-622$.

King, R.F., 1955. The remanent magnetism of artificially deposited sediments, Mon. Not. Roy. Astron. Soc. Geophys. Suppl., v. 10 , p. $115-134$.

Nakajima, T., Yaskawa, K., Natsuhara, N., Kawai, N., and Horie, S., 1973. Very short period geomagnetic excursion $18,000 \mathrm{yr}$ B.P., Nature Phys. Sci., v. 244, p. 8-10.

Pechersky, D.M. and Khramov, A.N., 1973. Mesozoic paleomagnetic scale of the U.S.S.R., Nature, v. 244, p. 499501 .

Ryan, W.B.F., Cita, M.B., Drayfus-Rawson, M., Burckle, L.H., and Saito, T., 1974. A paleomagnetic assignment of Neogene stage boundaries and the development of isochronous datum planes between the Mediterranean, the Pacific and Indian Oceans in order to investigate the response of the world ocean to the Mediterranean "salinity crisis," Riv. Ital.Paleontol., v. 80 , p. 631-688.

Soper, N.J., Downie, C., Higgins, A.C., and Costa, L.I., 1976. Biostratigraphic ages of Tertiary basalts on the East Greenland continental margin, and their relationship to plate separation in the Northeast Atlantic, Earth Planet. Sci. Lett., v. 32, p. 149 157.

van Hinte, J.E., 1976. A Cretaceous time scale, Am. Assoc, Petrol. Geol. Bull., v. 60, p. 498-516.

Van der Voo, R., and French, R.B., 1974. Apparent polar wandering for the Atlantic-bordering continents, Late Carboniferous to Eocene, Earth Sci. Rev., v. 10, p. 99-119. 

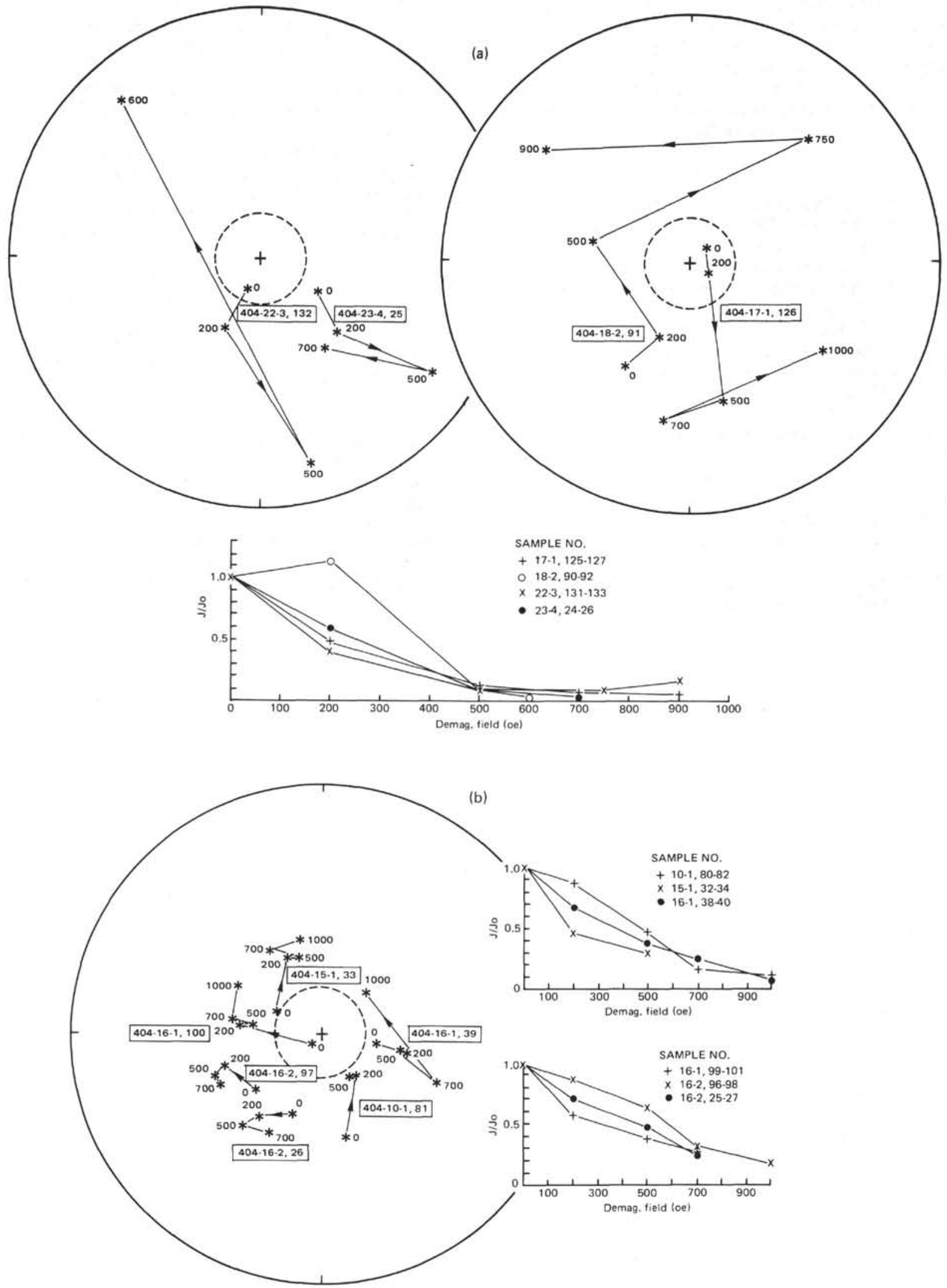

Figure 15. Examples of response to AF demagnetization of representative samples of normal polarity from Site 404. Symbols as in Figure 15. 


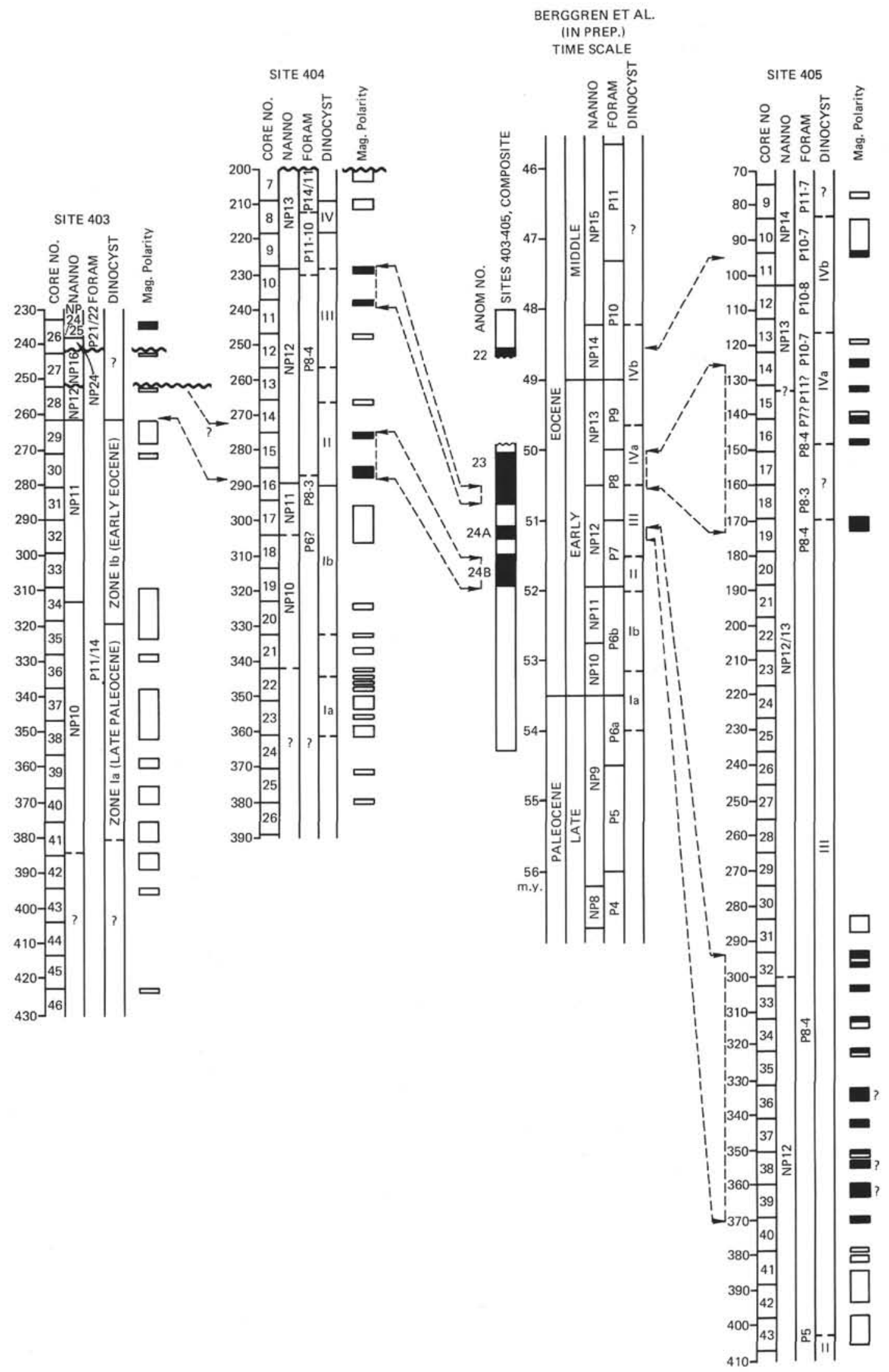

Figure 16. Comparison of magnetic polarity sequences at Sites 403, 404, and 405. Resultant composite polarity stratigraphy (central column) is correlated via biostratigraphic zones with the Paleogene timescale of Berggren et al. (in preparation). 
TABLE 5

Site 404: Paleomagnetic Results

\begin{tabular}{|c|c|c|c|c|c|c|c|c|c|c|c|}
\hline \multirow{3}{*}{$\begin{array}{c}\text { Sample } \\
\text { (Interval in } \mathrm{cm} \text { ) }\end{array}$} & \multirow[b]{3}{*}{ Depth } & \multirow[b]{3}{*}{ Dec. } & \multirow[b]{3}{*}{ Inc. } & \multirow{2}{*}{\multicolumn{6}{|c|}{$\begin{array}{r}\text { After Demagnetization } \\
\text { Int. }\end{array}$}} & \multirow{2}{*}{\multicolumn{2}{|c|}{ Category ${ }^{\mathrm{a}}$}} \\
\hline & & & & & & & & & & & \\
\hline & & & & $\left(\times 10^{-6} \mu \mathrm{G}\right)$ & Field & Dec. & Inc. & $\left(\times 10^{-6} \mu \mathrm{G}\right)$ & Polarity & Polarity & Direction \\
\hline $5-2,139-141$ & 182.90 & 65.0 & 72.6 & 33.80 & 200 & 65.3 & 75.6 & 20.0 & $\mathrm{~N}$ ? & 2 & 4 \\
\hline $7-1,39-41$ & 199.40 & 270.7 & -10.7 & 12.70 & 200 & 223.8 & -55.6 & 6.52 & $\mathrm{R}$ & 1 & 2 \\
\hline $7-2,95-97$ & 201.46 & 223.7 & -8.8 & 1.87 & 200 & 270.3 & -55.2 & 2.09 & $\mathrm{R}$ & 2 & 2 \\
\hline $7-2,118-120$ & 201.69 & 220.8 & -56.0 & 14.81 & 200 & 282.5 & -57.6 & 11.59 & $\mathrm{R}$ & 2 & 3 \\
\hline $7-3,8-10$ & 202.09 & 184.7 & -41.1 & 8.47 & 200 & 158.7 & -62.4 & 3.67 & $\mathrm{R}$ & 1 & 2 \\
\hline $7-3,53-55$ & 202.54 & 141.8 & -51.7 & 5.79 & 200 & 145.6 & -53.9 & 8.58 & $\mathrm{R}$ & 2 & 2 \\
\hline $7-3,83-85$ & 202.84 & 261.7 & -48.5 & 1.43 & 200 & 291.7 & -67.6 & 2.54 & $\mathrm{R}$ & 2 & 3 \\
\hline $8-1,46-48$ & 208.97 & 16.1 & 78.9 & 4.30 & 200 & 321.9 & -0.8 & 0.44 & $\mathrm{R}$ & 1 & 3 \\
\hline $8-1,131-133$ & 209.82 & 242.4 & 1.6 & 0.73 & 200 & 228.9 & -61.6 & 1.83 & $\mathrm{R}$ & 2 & 3 \\
\hline $8-2,15-17$ & 210.16 & 144.7 & 25.5 & 2.23 & 200 & 118.0 & -46.8 & 0.62 & $\mathrm{R}$ & 1 & 2 \\
\hline $8-2,47-49$ & 210.48 & 177.0 & 80.3 & 3.42 & 200 & 109.3 & -72.1 & 2.27 & $\mathrm{R}$ & 2 & 2 \\
\hline $10-1,35-37$ & 227.86 & 136.9 & 70.5 & 5.90 & 200 & 139.9 & 68.8 & 4.00 & $\mathrm{~N}$ & 2 & 2 \\
\hline $\begin{array}{l}10-1, \mathrm{CC} \\
80-82\end{array}$ & 228.31 & 164.4 & 42.7 & 13.68 & 200 & 139.9 & 65.8 & 6.23 & $\mathrm{~N}$ & 1 & 2 \\
\hline $\begin{array}{l}\text { 11-1, CC, } \\
53-55\end{array}$ & 237.54 & 252.5 & 68.6 & 26.70 & 200 & 260.4 & 66.0 & 13.02 & $\mathrm{~N}$ & 2 & 2 \\
\hline $12-1,60-62$ & 247.11 & 181.3 & -18.4 & 22.27 & 200 & 216.5 & -59.3 & 9.60 & $\mathrm{R}$ & 1 & 3 \\
\hline $14-1,39-41$ & 265.90 & 169.2 & -48.7 & 103.08 & 200 & 166.6 & -49.9 & 74.80 & $\mathrm{R}$ & 1 & 2 \\
\hline $15-1,32-34$ & 275.33 & 297.3 & 68.4 & 13.79 & 200 & 337.4 & 51.7 & 11.94 & $\mathrm{~N}$ & 1 & 2 \\
\hline $16-1,38-40$ & 284.89 & 120.8 & 63.8 & 18.17 & 200 & 124.0 & 51.4 & 12.10 & $\mathrm{~N}$ & 1 & 2 \\
\hline $16-1,99-101$ & 285.50 & 291.9 & 84.4 & 14.72 & 200 & 343.9 & 53.8 & 12.83 & $\mathrm{~N}$ & 1 & 2 \\
\hline $16-2,25-27$ & 286.26 & 285.6 & 52.6 & 31.47 & 200 & 304.4 & 44.7 & 18.06 & $\mathrm{~N}$ & 1 & 2 \\
\hline $16-2,96-98$ & 286.97 & 291.9 & 51.9 & 19.72 & 200 & 314.1 & 46.1 & 14.02 & $\mathrm{~N}$ & 1 & 2 \\
\hline $17-1,94-96$ & 294.95 & 223.6 & 86.8 & 102.11 & 200 & 357.4 & 77.4 & 37.05 & $\mathrm{~N}$ ? & 3 & 3 \\
\hline $17-1,125-127$ & 295.26 & 35.3 & 81.1 & 77.82 & 500 & 165.7 & 30.6 & 10.36 & $\mathrm{~N}$ ? & 3 & 3 \\
\hline $17-2,49-51$ & 296.00 & 115.9 & 76.4 & 39.00 & 500 & 326.0 & -32.6 & 11.31 & $\mathrm{R}$ ? & 4 & 4 \\
\hline $17-2,110-112$ & 296.61 & 145.4 & 62.0 & 30.75 & 500 & 314.1 & -54.3 & 14.51 & $\mathrm{R}$ ? & 3 & 4 \\
\hline $17-3,52-54$ & 297.53 & 295.9 & 50.6 & 25.39 & 500 & 221.3 & -63.9 & 11.51 & $\mathrm{R}$ ? & 2 & 3 \\
\hline $17-3,86-88$ & 297.87 & 214.9 & 65.9 & 43.42 & 500 & 115.3 & -70.6 & 8.10 & $\mathrm{R}$ & 2 & 3 \\
\hline $17-3,132-134$ & 298.33 & 335.2 & 45.3 & 99.41 & 200 & 263.1 & -56.2 & 13.05 & $\mathrm{R}$ & 1 & 2 \\
\hline $17-4,90-92$ & 299.41 & 287.7 & 85.5 & 40.39 & 500 & 83.5 & -75.4 & 9.21 & $\mathrm{R}$ & 2 & 3 \\
\hline $17-5,23-25$ & 300.24 & 203.2 & 84.5 & 21.84 & 500 & 4.8 & -60.3 & 7.07 & $\mathrm{R}$ & 2 & 3 \\
\hline $17-6,10-12$ & 301.61 & 336.5 & -28.0 & 9.50 & 200 & 324.0 & -81.4 & 12.58 & $\mathrm{R}$ & 2 & 2 \\
\hline $18-1,11-13$ & 303.62 & 307.3 & 56.3 & 42.38 & 500 & 280.3 & -56.2 & 1.10 & $\mathrm{R}$ & 2 & 3 \\
\hline $18-1,122-124$ & 304.73 & & & & 200 & 335.1 & -59.6 & 13.00 & $\mathrm{R}$ & 2 & 2 \\
\hline $18-2,44-46$ & 305.45 & 106.8 & 8.5 & 83.37 & 200 & 111.7 & -24.2 & 59.29 & $\mathrm{R}$ ? & 2 & 4 \\
\hline $18-2,90-92$ & 305.91 & 211.6 & 37.0 & 33.08 & 500 & 283.3 & 45.1 & 2.75 & $\mathrm{~N}$ ? & 3 & 4 \\
\hline $20-1,112-114$ & 323.63 & 34.8 & -74.8 & 27.08 & 200 & 40.6 & -87.3 & 10.23 & $\mathrm{R}$ & 2 & 4 \\
\hline $21-1,7-9$ & 332.08 & 56.4 & 71.9 & 9.98 & 500 & 22.7 & -52.8 & 5.83 & $\mathrm{R}$ & 1 & 2 \\
\hline $21-3,108-110$ & 336.09 & 146.1 & -21.7 & 10.63 & 200 & 95.4 & -70.2 & 11.13 & $\mathrm{R}$ & 2 & 3 \\
\hline $21-4,43-45$ & 336.94 & 203.3 & -41.1 & 18.12 & 200 & 220.6 & -59.0 & 15.41 & $\mathrm{R}$ & 2 & 2 \\
\hline $22-1,6-8$ & 341.57 & 0.0 & 62.1 & 26.23 & 500 & 346.6 & -17.2 & 4.26 & $\mathrm{R}$ ? & 3 & 3 \\
\hline $22-2,96-98$ & 343.95 & 164.9 & 21.0 & 4.57 & 500 & 262.8 & -28.2 & 1.31 & $\mathrm{R}$ ? & 3 & 3 \\
\hline $22-3,131-133$ & 345.82 & 204.4 & 56.7 & 12.75 & 500 & 165.0 & 8.6 & 1.17 & $\mathrm{~N}$ ? & 4 & 4 \\
\hline $22-4,136-138$ & 347.37 & 161.5 & 35.3 & 1.38 & 500 & 24.8 & -38.4 & 0.94 & $\mathrm{R}$ & 1 & 2 \\
\hline $22-5,19-21$ & 347.70 & 309.8 & 33.0 & 0.47 & 300 & 302.7 & -28.5 & 0.92 & $\mathrm{R}$ & 1 & 2 \\
\hline $22-6,81-83$ & 349.82 & 233.1 & -18.6 & 5.96 & 200 & 239.0 & -54.8 & 7.42 & $\mathrm{R}$ & 1 & 2 \\
\hline $23-1,23-25$ & 351.24 & 211.9 & 57.8 & 2.57 & 500 & 47.1 & -46.7 & 0.18 & $\mathrm{R}$ & 2 & 3 \\
\hline $23-2,24-26$ & 352.75 & 304.5 & -32.2 & 3.20 & 200 & 288.8 & -43.7 & 4.75 & $\mathrm{R}$ & 1 & 3 \\
\hline $23-3,147-149$ & 355.48 & 118.5 & -63.0 & 9.78 & 200 & 60.5 & -58.8 & 11.98 & $\mathrm{R}$ & 1 & 3 \\
\hline $23-4,24-26$ & 355.75 & 211.8 & 60.0 & 45.07 & 500 & 216.5 & 10.2 & 3.61 & $\mathrm{~N}$ ? & 3 & 3 \\
\hline $23-5,145-147$ & 358.46 & 139.6 & -54.4 & 5.95 & 200 & 89.0 & -63.2 & 6.68 & $\mathrm{R}$ & 1 & 3 \\
\hline $23-6,52-54$ & 359.03 & 121.9 & -47.2 & 65.55 & 200 & 126.2 & -66.2 & 82.18 & $\mathrm{R}$ & 1 & 2 \\
\hline $24-1,11-13$ & 360.62 & 108.8 & -12.6 & 11.77 & 500 & 321.1 & -3.3 & 1.70 & $\mathrm{R}$ ? & 4 & 4 \\
\hline $25-1,5-7$ & 370.06 & 325.3 & 11.9 & 103.21 & 300 & 308.1 & -4.3 & 24.39 & $\mathrm{R}$ & 3 & 2 \\
\hline $26-1,10-12$ & 379.61 & 194.2 & -10.1 & 256.15 & 300 & 248.1 & -35.7 & 37.76 & $\mathrm{R}$ ? & 1 & 3 \\
\hline
\end{tabular}

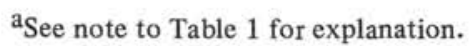




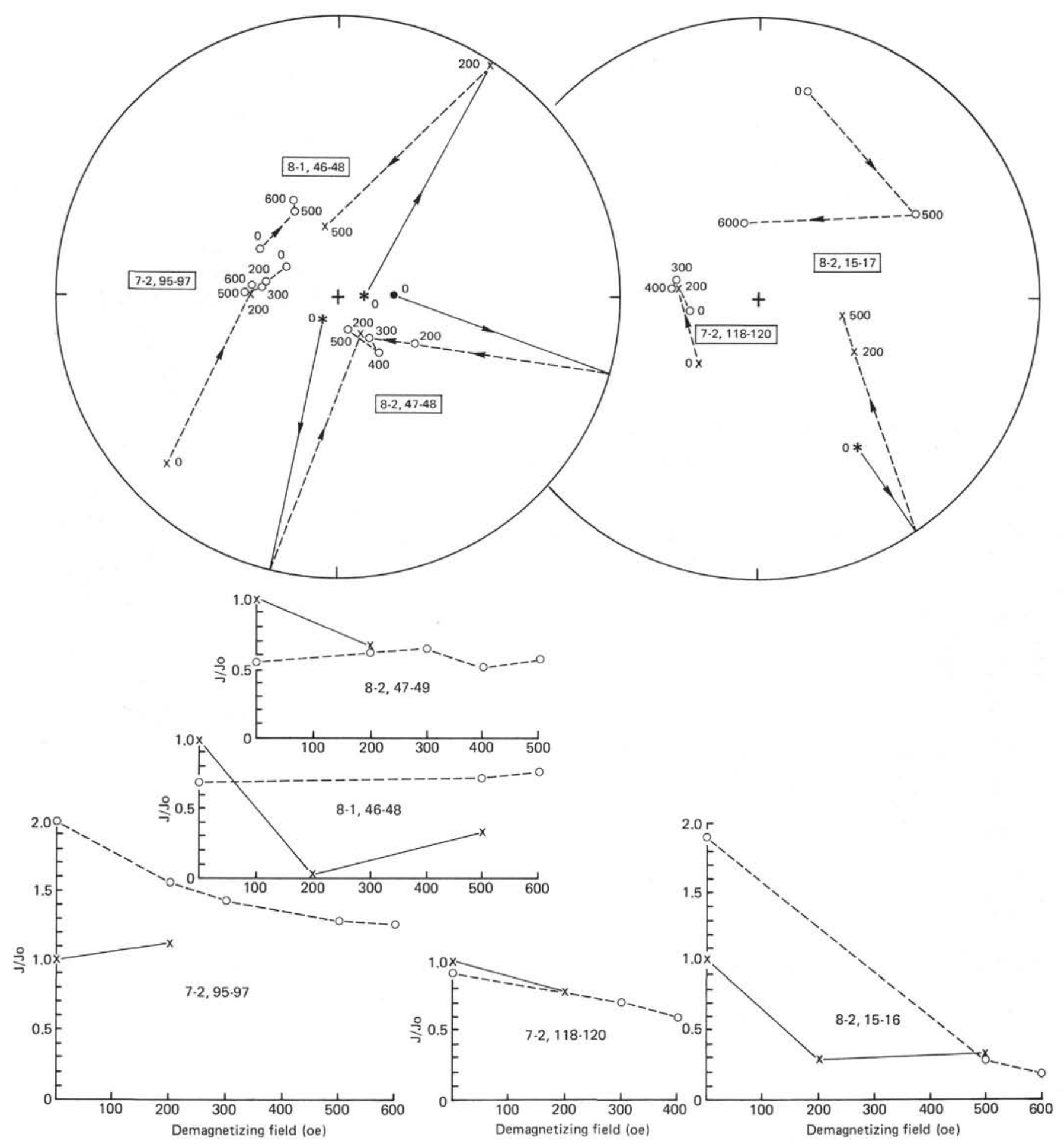

Figure 17. Examples of response to AF demagnetization of representative samples of reverse polarity from Site 404. Symbols as in Figure 15. 
SITE 403
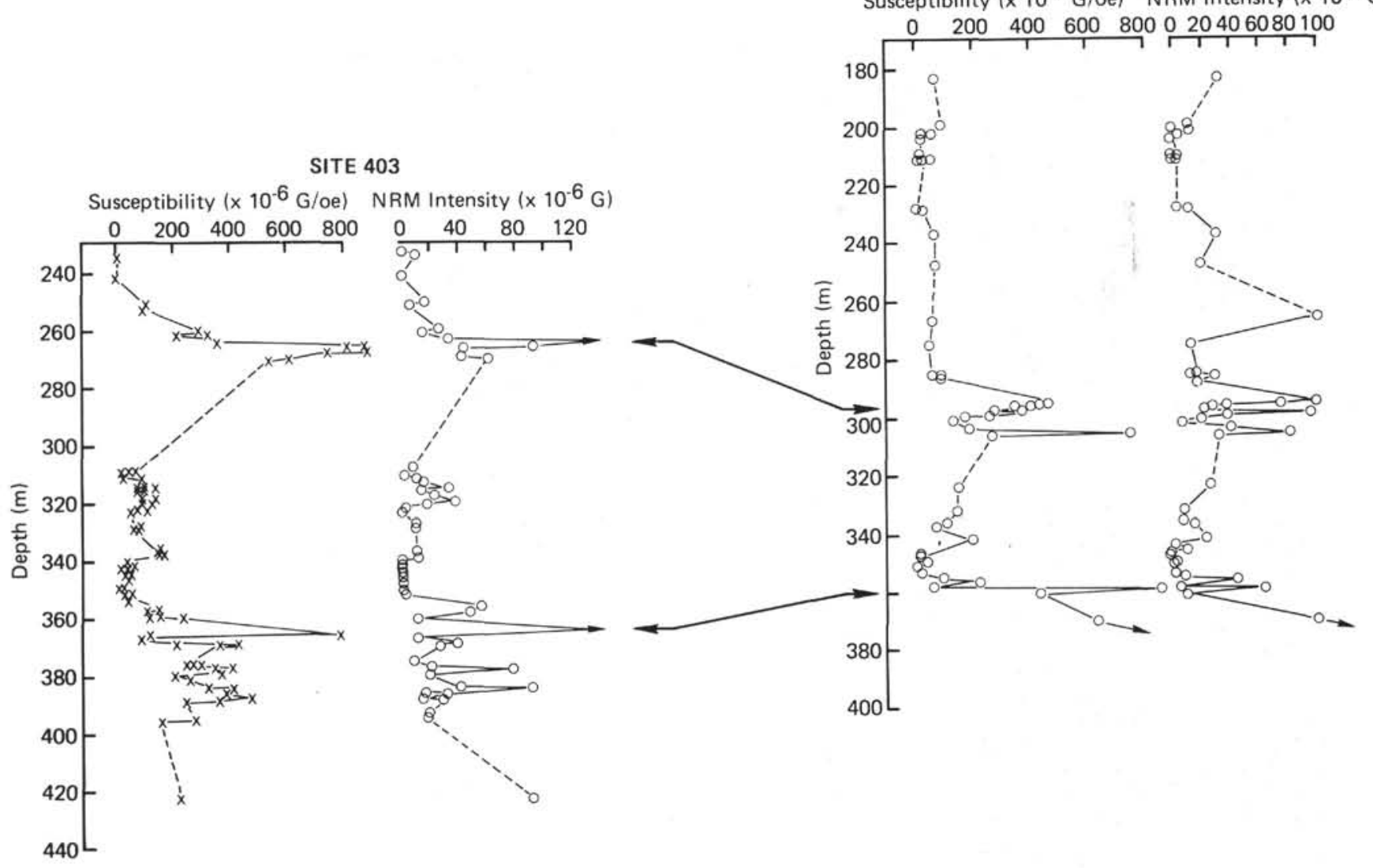

SITE 404

Susceptibility ( $\left.\times 10^{-6} \mathrm{G} / \mathrm{oe}\right) \quad$ NRM Intensity $\left(\times 10^{-6} \mathrm{G}\right)$

Figure 18. Correlation between magnetic susceptibility and NRM intensity records for Sites 403 and 404. 
TABLE 6

Site 405: Paleomagnetic Results

\begin{tabular}{|c|c|c|c|c|c|c|c|c|c|c|c|}
\hline \multirow{2}{*}{$\begin{array}{c}\text { Sample } \\
\text { (Interval in } \mathrm{cm} \text { ) }\end{array}$} & \multicolumn{9}{|c|}{ Demag. } & \multicolumn{2}{|c|}{ Category $^{a}$} \\
\hline & Depth & Dec. & Inc. & Int. & Field & Dec. & Inc. & Int. & Polarity & Polarity & Direction \\
\hline $9-2,65-67$ & 76.66 & 135.4 & -22.6 & 9.72 & 300 & 136.2 & -22.7 & 2.58 & $\mathrm{R}$ & 1 & 1 \\
\hline $10-1,58-60$ & 84.59 & 91.3 & -38.9 & 1.29 & 300 & 123.5 & -33.4 & 0.95 & $\mathrm{R}$ & 1 & 1 \\
\hline $10-2,65-67$ & 86.16 & 145.7 & -40.4 & 21.67 & 300 & 145.6 & -36.1 & 5.51 & $\mathrm{R}$ & 1 & 1 \\
\hline $10-3,69-71$ & 87.70 & 165.2 & -51.9 & 17.75 & 300 & 164.7 & -56.1 & 3.84 & $\mathrm{R}$ & 1 & 1 \\
\hline $10-4,67-69$ & 89.18 & 102.7 & -73.7 & 3.25 & 300 & 130.5 & -48.7 & 0.89 & $\mathrm{R}$ & 1 & 2 \\
\hline $10-5,70-72$ & 90.71 & 170.3 & -39.5 & 9.71 & 300 & 173.7 & -40.1 & 1.76 & $\mathbf{R}$ & 1 & 1 \\
\hline $10-6,26-28$ & 91.77 & 144.0 & -78.8 & 2.16 & 300 & 353.3 & -72.4 & 0.58 & $\mathrm{R}$ & 1 & 3 \\
\hline $10-7,26-28$ & 93.27 & 212.4 & -41.1 & 1.76 & 300 & 206.4 & -34.0 & 1.22 & $\mathrm{R}$ & 1 & 1 \\
\hline $11-1,55-57$ & 94.06 & 291.8 & 20.5 & 21.78 & 300 & 292.3 & 22.7 & 12.45 & $\mathrm{~N}$ & 1 & 1 \\
\hline $13-5,64-66$ & 119.15 & 92.0 & -42.9 & 34.41 & 300 & 86.0 & -50.6 & 19.37 & $\mathrm{R}$ & 1 & 1 \\
\hline $14-2,145-147$ & 124.96 & 185.5 & 76.9 & 15.02 & 300 & 171.9 & 80.5 & 5.64 & $\mathrm{~N}$ & 1 & 1 \\
\hline $14-3,6-8$ & 125.07 & 137.6 & 51.2 & 42.91 & 300 & 134.5 & 51.1 & 16.15 & $\mathrm{~N}$ & 1 & 1 \\
\hline $15-1,80-82$ & 132.31 & 38.1 & 63.3 & 50.05 & 300 & 37.9 & 59.3 & 16.30 & $\mathrm{~N}$ & 1 & 1 \\
\hline $15-7,57-59$ & 139.58 & 151.6 & -35.0 & 31.16 & 300 & 164.2 & -39.4 & 12.17 & $\mathrm{R}$ & 1 & 1 \\
\hline $16-1,47-49$ & 141.48 & 1.2 & 57.3 & 29.85 & 300 & 2.7 & 48.3 & 12.10 & $\mathrm{~N}$ & 1 & 1 \\
\hline $16-5,58-60$ & 147.59 & 236.1 & 22.2 & 21.96 & 300 & 239.8 & 17.8 & 9.84 & $\mathrm{~N}$ & 1 & 1 \\
\hline $19-1,41-43$ & 169.92 & 203.6 & 53.2 & 20.26 & 300 & 34.2 & 79.1 & 1.21 & $\mathrm{~N}$ & 1 & 1 \\
\hline $19-1,108-110$ & 170.59 & 9.0 & 66.8 & 15.83 & 300 & 218.8 & 60.1 & 5.12 & $\mathrm{~N}$ & 1 & 1 \\
\hline $19-2,57-59$ & 171.58 & 18.9 & 55.7 & 8.53 & 300 & 35.6 & 50.1 & 1.42 & $\mathrm{~N}$ & 1 & 1 \\
\hline $19-3,20-22$ & 172.71 & 201.1 & 69.3 & 15.75 & 300 & 217.7 & 61.6 & 5.49 & $\mathrm{~N}$ & 1 & 1 \\
\hline $31-1,18-20$ & 283.69 & 206.7 & -26.5 & 29.56 & 300 & 234.8 & -46.5 & 12.10 & $\mathrm{R}$ & 1 & 1 \\
\hline $31-2,21-23$ & 285.22 & 165.7 & -7.4 & 44.61 & 300 & 160.3 & -27.1 & 11.16 & $\mathrm{R}$ & 1 & 1 \\
\hline $31-2,130-132$ & 286.31 & 135.8 & -20.5 & 54.63 & 300 & 121.4 & -41.6 & 17.78 & $\mathrm{R}$ & 1 & 1 \\
\hline $31-3,57-59$ & 287.08 & 159.1 & -16.0 & 18.71 & 300 & 146.6 & -24.6 & 9.51 & $\mathrm{R}$ & 1 & 1 \\
\hline $32-1,17-19$ & 293.18 & 356.8 & -37.4 & 52.15 & 300 & 349.9 & -41.2 & 23.86 & $\mathrm{R}$ & 1 & 1 \\
\hline $32-1,123-125$ & 294.24 & 250.6 & -4.1 & 22.21 & 300 & 274.1 & 25.5 & 9.95 & $\mathrm{~N}$ & 1 & 1 \\
\hline $32-2,30-32$ & 294.81 & 188.3 & -9.9 & 39.60 & 300 & 179.6 & -26.3 & 15.25 & $\mathrm{R}$ & 1 & 1 \\
\hline $32-3,6-8$ & 296.07 & 91.4 & 67.6 & 7.42 & 350 & 30.8 & -24.8 & 4.39 & $\mathrm{R}$ & 2 & 2 \\
\hline $32-3,71-73$ & 296.72 & 210.1 & 36.9 & 22.50 & 500 & 203.1 & 29.4 & 7.49 & $\mathrm{~N}$ & 1 & 1 \\
\hline $33-1,37-39$ & 302.88 & 168.2 & 13.0 & 11.62 & 500 & 190.8 & 1.3 & 9.63 & $\mathrm{~N}$ ? & 3 & 1 \\
\hline $33-1,103-105$ & 303.54 & 15.0 & 32.6 & 25.35 & 500 & 11.2 & 30.9 & 6.61 & $\mathrm{~N}$ & 1 & 1 \\
\hline $34-1,29-31$ & 312.30 & 48.8 & 56.9 & 56.62 & 500 & 72.0 & 49.4 & 12.20 & $\mathrm{~N}$ & 1 & 1 \\
\hline $34-1,141-143$ & 313.42 & 221.7 & 64.1 & 4.82 & 300 & 172.0 & -34.4 & 3.47 & $\mathrm{R}$ & 1 & 2 \\
\hline $34-2,144-146$ & 314.95 & 347.1 & -18.4 & 43.93 & 300 & 344.6 & -36.6 & 15.38 & $\mathrm{R}$ & 1 & 2 \\
\hline $35-1,20-22$ & 321.71 & 255.1 & 67.5 & 22.78 & 500 & 247.6 & 51.2 & 2.75 & $\mathrm{~N}$ & 1 & 1 \\
\hline $35-1,108-110$ & 322.59 & 309.0 & 27.0 & 3.78 & 500 & 224.6 & -15.3 & 1.00 & $\mathrm{R}$ & 1 & 1 \\
\hline $36-1,129-131$ & 332.50 & 149.5 & 29.5 & 15.66 & 300 & 141.8 & 17.2 & 6.21 & $\mathrm{~N}$ & 2 & 2 \\
\hline $36-2,18-20$ & 332.69 & 63.0 & 39.7 & 21.84 & 300 & 65.1 & 29.7 & 6.92 & $\mathrm{~N}$ & 2 & 1 \\
\hline $36-2,112-114$ & 333.63 & 32.6 & 35.6 & 63.01 & 300 & 37.5 & 27.4 & 19.83 & $\mathrm{~N}$ & 1 & 1 \\
\hline $36-3,11-13$ & 334.12 & 180.9 & 27.8 & 52.33 & 300 & 172.9 & 15.6 & 18.84 & $\mathrm{~N}$ & 1 & 1 \\
\hline $36-3,107-109$ & 335.08 & 71.1 & 25.6 & 25.98 & 300 & 76.4 & 29.9 & 9.34 & $\mathrm{~N}$ & 1 & 1 \\
\hline 37-1, 99-101 & 341.50 & 346.9 & 33.9 & 18.67 & 500 & 320.7 & 36.4 & 1.54 & $\mathrm{~N}$ & 2 & 2 \\
\hline $37-2,54-56$ & 342.55 & 139.1 & 37.1 & 20.37 & 500 & 136.5 & 30.3 & 2.35 & $\mathrm{~N}$ & 1 & 2 \\
\hline $38-1,17-19$ & 350.18 & 127.0 & 30.0 & 57.91 & 500 & 121.6 & 20.6 & 10.94 & $\mathrm{~N}$ & 1 & 1 \\
\hline $38-2,35-37$ & 351.86 & 148.8 & 20.3 & 53.62 & 500 & 150.4 & -2.1 & 4.29 & $\mathrm{R}$ ? & 3 & 2 \\
\hline $38-3,52-54$ & 353.53 & 279.0 & 50.2 & 41.01 & 500 & 280.3 & 28.6 & 6.45 & $\mathrm{~N}$ & 2 & 2 \\
\hline $38-4,6-8$ & 354.57 & 126.9 & 35.9 & 34.06 & 500 & 116.9 & 18.0 & 4.90 & $\mathrm{~N}$ & 1 & 2 \\
\hline $41-3,16-18$ & 381.67 & 42.5 & -18.9 & 82.81 & 200 & 44.6 & -26.5 & 63.81 & $\mathrm{R}$ & 1 & 1 \\
\hline $41-4,27-29$ & 384.78 & 255.6 & -16.9 & 80.13 & 200 & 230.5 & -23.9 & 69.81 & $\mathrm{R}$ & 1 & 1 \\
\hline $41-5,43-45$ & 384.94 & 203.9 & -13.5 & 97.24 & 200 & 198.6 & -18.6 & 181.60 & $\mathrm{R}$ & 1 & 1 \\
\hline $41-6,30-32$ & 386.31 & 349.3 & -2.2 & 61.63 & 200 & 351.4 & -12.5 & 43.99 & $\mathrm{R}$ & 1 & 1 \\
\hline $42-1,1-3$ & 388.02 & 298.4 & -14.6 & 95.97 & 200 & 286.1 & -19.4 & 70.33 & $\mathrm{R}$ & 1 & 1 \\
\hline $42-2,21-23$ & 389.72 & 100.0 & -29.2 & 137.02 & 200 & 103.7 & -30.1 & 98.50 & $\mathrm{R}$ & 1 & 1 \\
\hline $42-3,6-8$ & 391.07 & 326.6 & -33.5 & 92.62 & 200 & 313.7 & -40.3 & 59.43 & $\mathrm{R}$ & 1 & 1 \\
\hline $42-4,56-58$ & 393.07 & 279.8 & -32.5 & 93.95 & 200 & 279.1 & -37.2 & 62.72 & $\mathrm{R}$ & 1 & 1 \\
\hline $43-1,21-23$ & 397.72 & 149.2 & 10.4 & 50.61 & 500 & 130.6 & -9.0 & 2.96 & $\mathrm{R}$ & 1 & 1 \\
\hline $43-2,93-95$ & 399.94 & 7.6 & -9.7 & 69.73 & 200 & 16.2 & -16.7 & 33.42 & $\mathrm{R}$ & 1 & 1 \\
\hline $43-3,7-9$ & 400.58 & 118.2 & -21.4 & 91.27 & 200 & 133.4 & -32.7 & 56.25 & $\mathrm{R}$ & 1 & 1 \\
\hline $43-4,37-39$ & 402.38 & 242.7 & -45.3 & 83.71 & 500 & 242.6 & -41.2 & 17.92 & $\mathrm{R}$ & 1 & 1 \\
\hline $43-5,25-27$ & 402.76 & 154.4 & -31.1 & 92.17 & 200 & 163.0 & -28.1 & 77.49 & $\mathrm{R}$ & 1 & 1 \\
\hline $43-6,18-20$ & 405.19 & 10.8 & -7.6 & 65.25 & 200 & 14.4 & -11.5 & 48.17 & $\mathrm{R}$ & 1 & 1 \\
\hline
\end{tabular}

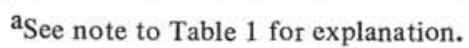



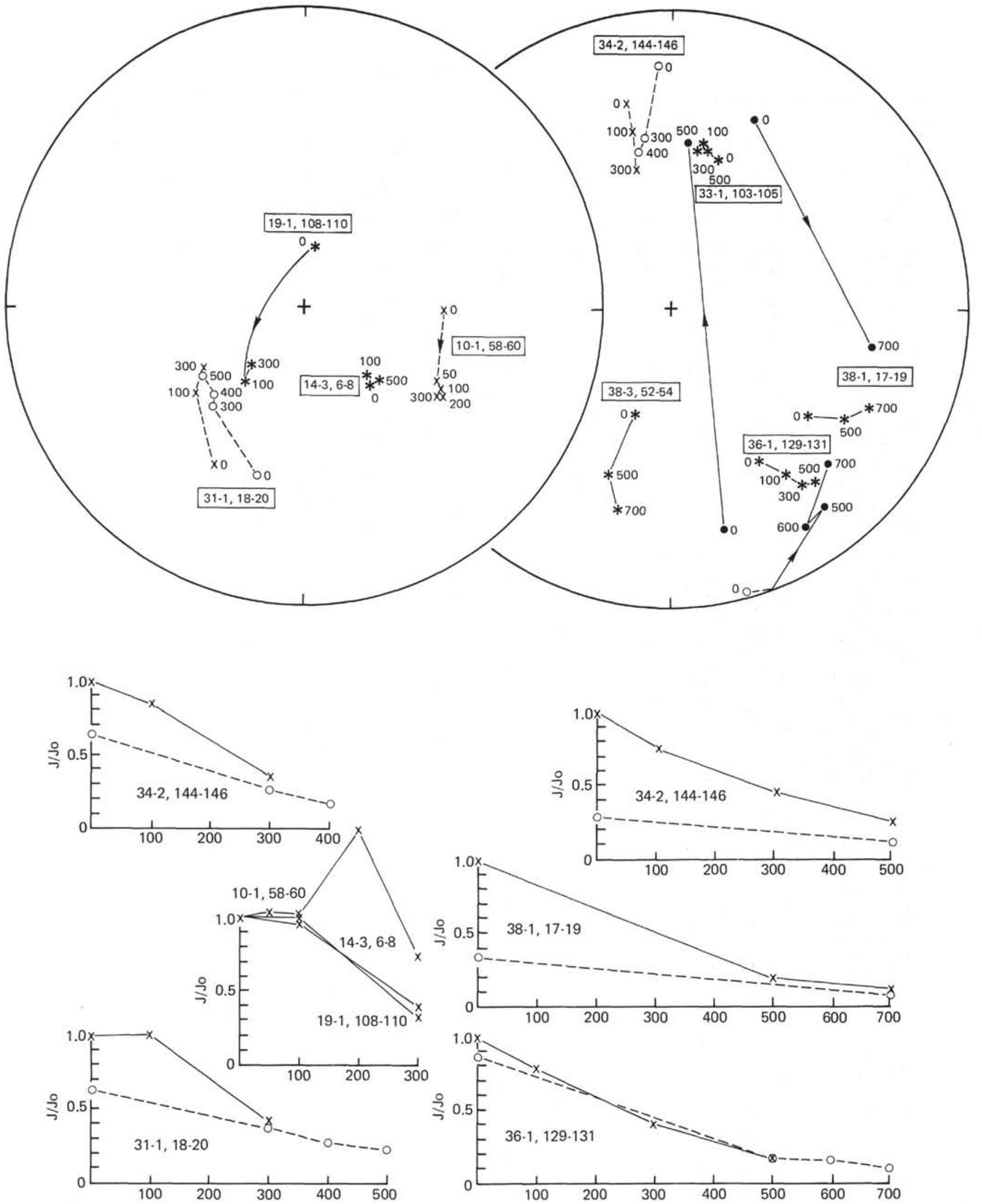

Figure 19. Examples of response to AF demagnetization of representative samples from Site 405. Symbols as in Figure 15. 